PNL-7258

UC-721

SST Sample Characterization

Analysis of Archive Samples

102-C, 105-C, and 106-C
F. T. Hara
R. W. Stromatt
J. H. Kaye
D. L. Thomas
R. T. Steele
M. W. Urie

April 1990

Work supported by

the U.S. Department of Energy

under Contract DE-AC06-76RLO 1830

Pacific Northwest Laboratory

Operated for the U.S. Department of Energy

by Battelle Memorial Institute 


\section{DISCLAIMER}

This report was prepared as an account of work sponsored by an agency of the United States Covernment. Neither the United States Covernment nor any agency thereof, nor Battelie Memorial Institute, nor any of their empioyees, makes any warranty, expressed or implied, or assumes any legal liability of responsibility for the accuracy, completeness, or usefulness of any information, apparatus, product, or process disclosed, or represents that its use would not infringe privately owned rights. Reference herein to any specific commercial product, process, or service by trade name, trademark, manufacturer, or otherwise, does not necessarily constitute or imply its endorsement, recommendation, or favoring by the United States Government of any agency thereof, or Battelle Memorial Institute. The views and opinions of authors expressed herein do not necessarily state or reflect those of the United States Government or any agency thereof.

\section{PACIFIC NORTHWEST LABORATORY operated by \\ BATTELLE MEMORIALINSTITUTE for the \\ UNITED STATES DEPARTMENT OF ENERGY under Contract DE-ACO6-76RLO 1830}

\section{Printed in the United States of America}

Available to DOE and DOE contractors from the

Office of Scjentííc and Technical Information, P.O. Box 62, Oak Ridge, JN 37831; prices available from (615) 576-8401. FTS 626-8401.

Available to the public from the National Technical Information Service, U.S. Department of Commerce, 5285 Port Royal Rd., Springtield, VA 22161.

NTIS Price Codes, Microtiche A01

Printed Copy

\begin{tabular}{cr}
\hline Price Code & Page Range \\
\hline A02 & $1-10$ \\
A03 & $11-50$ \\
A04 & $51-75$ \\
A05 & $76-100$ \\
A06 & $10 t-125$ \\
A07 & $126-150$ \\
A06 & $15 t-175$ \\
A09 & $176-200$ \\
A10 & $207-225$ \\
A11 & $226-250$ \\
A12 & $251-275$ \\
A13 & $276-300$ \\
A14 & $301-325$
\end{tabular}

\begin{tabular}{cc}
\hline Price Code & Page Range \\
\hline A15 & $326-350$ \\
A16 & $351-375$ \\
A17 & $376-400$ \\
A18 & $401-425$ \\
A19 & $426-450$ \\
A20 & $451-475$ \\
A21 & $476-500$ \\
A22 & $501-525$ \\
A23 & $526-550$ \\
A24 & $551-575$ \\
A25 & $576-600$ \\
A99 & $601-U P$
\end{tabular}


PNL -7258

UC -721

SST SAMPLE CHARACTERIZATION ANALYSIS OF ARCHIVE SAMPLES 102-C, 105-C, AND 106-C
F. T. Hara
J. H. Kaye
R. T. Steele
R. W. Stromatt
D. L. Thomas
M. W. Urie

\title{
Apri1 1990
}

\author{
Work supported by \\ the U.S. Department of Energy \\ under Contract DE-ACO6-76RLO 1830
}

Pacific Northwest Laboratory

Richland, Washington 99352 
-

,

1

- 


\section{EXECUTIVE SUMMARY}

A substantial effort is planned to be initiated at the Hanford Site regarding the characterization of 149 singte-shell tanks (SSTs) containing the byproducts of reprocessing during the 1950s and 1960s. Sampling and analysis, in distinct phases, are planned to involve laboratory investigations to determine both chemical and radionuclide inventories, so that waste disposal decisions can be developed.

During 1989, trial analyses were performed on four archived samples from SSTs at the Pacific Northwest Laboratory using established U.S. EnvironmentaT Protection Agency (EPA) protocols and radiochemical procedures.

The analysis of the archived SST waste material provides three important types of data for use in planning Phase I-A and Phase I-B sample analysis. The types of data served as input to 1) finalizing the waste sample analysis procedures and methods and identify where procedure development may be needed, 2) evaluating the impact of normal paraffin hydrocarbon (NPH) lubricant (used in field sampling) on extracting inorganics or radionuclides from the SST sample, and 3) identifying trends in amounts of occupationa] radiation exposure expected from performing the various analysis procedures.

Overall, the results are qualitative in nature, and the conclusions given are to be used with appropriate respect for the limitations of smatl amounts of data from four samples used in development processes. The results of the Phase I-A and I-B sample analysis will provide essential data for method performance for use in finalizing Phase $I-C$ planning and methods development scope.

Section 2.0, Inorganic Analysis, encompasses sample preparation, sample analysis, identification of methods performance limitations, and possible a] ternatives. Performance of the inorganic analytical methods was evaluated and changes were made to some of the procedures. In some cases, inductiveiy coupled plasma-atomic emission spectroscopy (referred to in this report as ICP) did not provide the levels of accuracy and precision usually required for EPA work due to interference by other elements. In these cases, other methods are suggested as appropriate for trial as alternatives. In alt 
cases, duplicates, spikes, and blanks were used to establish performance of the methods for the specific waste matrix. Results focused on problems in using the methods tested on the samples, the suitability of the ICP method of determining EP Toxicity metal ions and 22 EPA pollutant metal ions, and the suitability of cold vapor atomic absorption (CVAA) for mercury determinations. Problems areas identified are ICP spectral corrections, poor reproducibility from water leach and EP Toxicity methods, and adjustments needed for mercury analysis by CVAA.

Section 3.0, Organics Analysis, details two screening procedures [tota] organic carbon (TOC) and gas chromatography (GC)], extraction procedures and related problems, surrogate spiking to test extraction efficiencies and matrix effects, and semivolatile organics via GC/mass spectroscopy (MS). The results show that the GC/MS is vulnerable to fouling and overload and that a combination of dilution and perhaps acidification are required to provide acceptable results. NPH and silicone-based lubricants from the sampling process impact the semivolatile analysis; however, with some modification the semivolatile method based on EPA SOW 288 can be used.

Section 4.0, Radionuclide Analysis, evaluates procedures used to measure the radionuclides that might be found in the SST tank waste samples and establishes the level of accuracy and precision that can be expected. These data reveal that additional procedure development is needed in order to measure all of the radionuclides listed in Table 4-14 of the Waste Characterization Plan. In addition, the archive samples analyzed may not be representative of the tank population and considerable adaptation of the radiochemical procedures may be necessary to perform the desired measurenents.

NPH tests were conducted to determine whether the NPH from the field sampling process extracted significant quantities of the inorganics or radionuclides from the SST samples. Results indicate that no such extraction is anticipated; however, the NPH does have a significant effect on the organic analysis and its use should be investigated.

Trends in expected occupational exposure were obtained by measuring the radiation level of samples and having the analysts record estimates of the 
contact time with the samples. Data revealed that the analysts received no significant exposure and that, as expected, the potential dose is directly proportional to the sample size and handling times. 
$\because$

$\because$

.

.

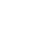




\section{CONTENTS}

EXECUTIVE SUMMARY $\ldots \ldots \ldots \ldots \ldots \ldots \ldots$ i $\ldots \ldots \ldots$

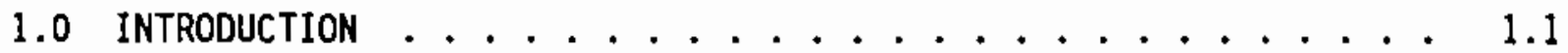

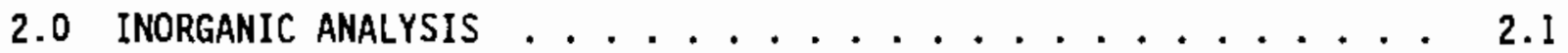

2.1 TEST METHODS, RESULTS, AND SIGNIFICANCE . . . . . . 2.1

2.1.1 Sample Preparation ............ 2.1

2.1.2 Percent Solids Determination ........ 2.2

2.1.3 Water Leach . . . . . . . . . . 2.2

2.1 .4 EP Toxicity . . . . . . . . . 2.3

2.1.5 Acid Digestion ........... 2.4

2.1 .6 Fusion: ICP Anatysis ........... 2.5

2.1.7 Comparison of Water Leach, EP Toxicity, Acid Digestion, and Total Fusion ICP

Analysis Results ............. 2.5

2.1.8 Mercury Analys is by Cold Vapor Atomic Absorption (CVAA) ................ 2.6

2.1 .9 Total Cyanide . . . . . . . . . . 2.6

2.2 PROBLEM AREAS AND CORRECTIVE ACTIONS ......... 2.7

2.2.] ICP Spectral Corrections . . . . . . . . 2.7

2.2.2 Poor Reproducibility from Water Leach and
EP Toxicity Methods ............... 2.7

2.2.3 Modification to CVAA Method .......... 2.8

2.3 TEST PLAN OBJECTIVES . . . . . . . . . . 2.8

2.3.1 To Determine if There Are Problems with

Employing the Various Analytical Methods

on the Test Samples............. 2.8

2.3.2 To Determine if the ICP Has Sufficient

Sensitivity for Analysis of the EP Toxicity

Metal Ions (excluding $\mathrm{Hg}$ ) . . . . . . . 2.9 
2.3.3 To Determine which of the 22 EPA Pollutant

Metal Ions Can Be Determined by ICP Analysis ... 2.9

2.3.4 To Determine if Mercury Can Be Determined by

the CVAA Method ............. 2...

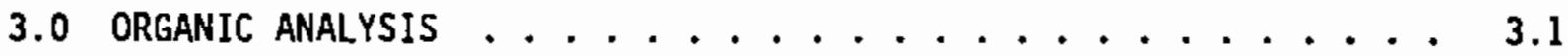

3.1 TEST METHODS, RESULTS, AND SIGNIFICANCE . . . . . . . 3.1

3.1.1 Target Compounds .................... 3.1

3.1.2 Tentatively Identified Compounds . . . . . . 3.2

3.1.3 Surrogate and Matrix Spike Test.......... 3.2

3.1.4 Experimentāt . . . . . . . . . . . . 3.2

3.1 .5 Screening . . . . . . . . . . . 3.3

3.2 PROBLEM AREAS AND CORRECTIVE ACTIONS .......... 3.3

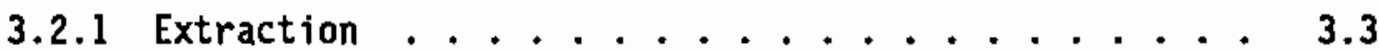

3.2.2 Sample Concentration and Composition ...... 3.4

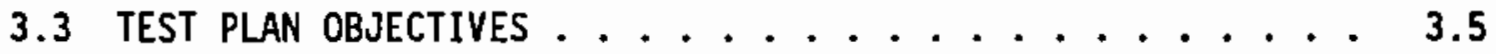

3.3.1 To Determine Whether the EPA Semivolatile
Organic Method Can Be Employed on SST Sampies . . . 3.5

4.0 RADIONUCLIDE ANALYSIS . . . . . . . . . . . . . . 4.1

4.1 TEST METHODS, RESULTS, AND SIGNIFICANCE $\ldots \ldots \ldots . . . . .4 .1$

4.1.1 Sample Fusion ............... 4.1

4.1.2 Sumnary of Radiochemical Measurements . . . . . 4.1

4.2 PROBLEM AREAS AND CORRECTIVE ACTIONS ......... 4.2

4.2 .1 Radionuclide ${ }^{227} \mathrm{AC} \ldots \ldots . . . \ldots 4.3$

4.2.2 Radionuclides ${ }^{249} \mathrm{Am},{ }^{242} \mathrm{Am},{ }^{243} \mathrm{Am}$, and ${ }^{242} \mathrm{Cm} . \ldots 4.3$

4.2 .3 Radionuclides ${ }^{135} \mathrm{Cs}$ and ${ }^{137} \mathrm{Cs} \ldots . . . . . .4 .4$

4.2 .4 Radionuclides ${ }^{59} \mathrm{Ni}$ and ${ }^{63} \mathrm{Ni} \ldots . . . . . .44$

4.2 .5 Radionuclides ${ }^{94} \mathrm{Nb},{ }^{231} \mathrm{~Pa}$, and ${ }^{93} \mathrm{Zr} \ldots . . . .4 .4$ 
2.11 Comparison of ICP KOH Fusion Results for SST Samples 102-C, 105-C, and 106-C ........... 2. . . . .

2.12 Direct Comparison of the Test Methods by ICP for SST Sample 102-C ................ 2.21

2.13 Summary of EP Toxicity Metal Ions by ICP . . . . . . . . . 2.22

2.14 Summary of EPA Pollutant Metal lons by ICP . . . . . . . . 2.22

4.1 Total Alpha, Total Beta, and GEA Results for SST Samples 105-C and 106-C . . . . . . . . . . . . 4.7

4.2 Radiochemical Measurements and Tracer Yields for SST Samples 105-C and 106-C . . . . . . . . . . 4.8

4.3 Uranium Isotopic Analyses on SST Samples 105-C and 106-C.................. 4.9

5.1 ICP and IC Measurements for NPH Equilibrated with Composite of SST Samples 106-C and 102-AX ........ 5.3

5.2 Total Alpha, Total Beta, and GEA Results on NPH Equilibrated with Composite of SST Samples 106-C and 102-AX . . . . . . 5.4

6.1 Exposure Data Summary for Radiochenical Separations . . . . . 6.2

6.2 Exposure Data Sumary for Inorganic Analyses . . . . . . . . 6.3 


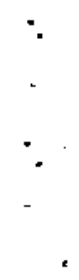

. 
4.2 .6 Radionuclides ${ }^{210} \mathrm{~Pb},{ }^{226} \mathrm{Ra}$, and ${ }^{228} \mathrm{Ra} \ldots \ldots . . .4 .5$

4.2 .7 Radionuclide ${ }^{210} \mathrm{po}_{0} \ldots \ldots \ldots . \ldots . \ldots 4 . \ldots$

4.2 .8 Radionuclides ${ }^{238} \mathrm{Pu},{ }^{239} \mathrm{Pu},{ }^{260} \mathrm{Pu}$, and ${ }^{242} \mathrm{Pu}$. . . 4.5

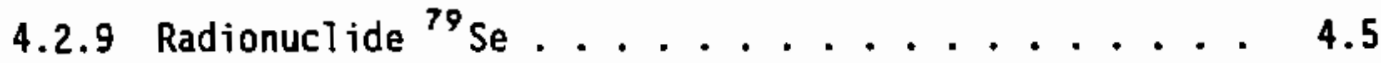

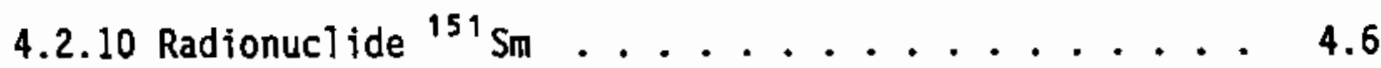

4.2.11 Radionuclides ${ }^{229} \mathrm{Th},{ }^{230} \mathrm{Th}$, and ${ }^{232} \mathrm{Th} \ldots . . . .4 .6$

4.2.12 Radionuclides ${ }^{233} \mathrm{U},{ }^{234} \mathrm{U},{ }^{235} \mathrm{U},{ }^{236} \mathrm{U}$, and ${ }^{238} \mathrm{U} . \ldots .4 .6$

4.2 .13 Total U.................. 4.7

4.3 TEST Plan 0 OBJeCTIVES . . . . . . . . . . . . . 4.7

\subsubsection{To Determine if There Are Problems With}

Employing the Various Analytical Methods

on the Test Samples............. 4.7

5.0 NORMAL PARAFFIN HYDROCARBON STUdIES . . . . . . . . 5.1

5.1 TEST METHODS, RESULTS, AND SIGNIFICANCE . . . . . . 5.1

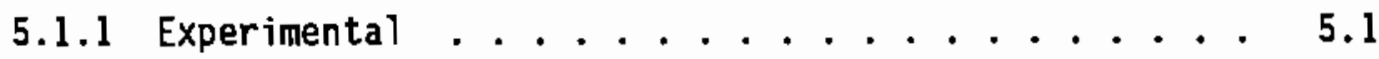

5.1.2 ICP Inorganic Constituent Solubility Results .... 5.I

5.1.3 Radionuclide Solubility Results . . . . . . . 5.2

5.2 TEST PLAN OBJECTIVES . . . . . . . . . . . . 5.2

5.2.1 To Determine the Solubility of Inorganic
and Radiochemical Ions in NPH . . . . . . . 5.2

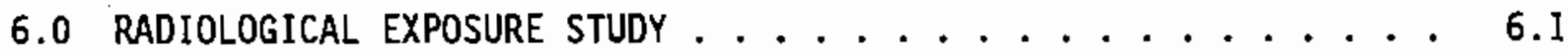

6.1 TEST METHOOS, RESULTS, AND SIGNIFICANCE . . . . . . 6.1

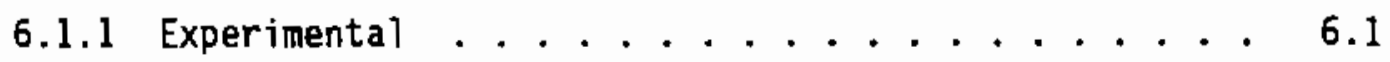

6.1 .2 Exposure Summary ............. 6.1

APPENDIX - TEST PLAN FOR ANALYSIS OF ARCHIVE SAMPLES OF

SINGLE-SHELL TANK SAMPLES PROVIDED BY

WESTINGHOUSE HANFORD COMPANY 


\section{FIGURES}

3.1 Semivolatile Organics Analysis Data Sheet . . . . . . . 3.7

3.2 Semivolatile Organics Analysis Data Sheet ........ 3.9

3.3 Semivolatile Organics Anatysis Data Sheet . . . . . . . 3.11

3.4 Semivolatile Organics Analysis Data Sheet Tentatively

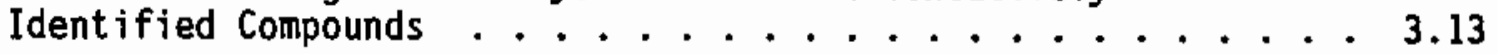

3.5 Semivolatile Organics Analysis Data Sheet Tentatively Identified Compounds ................. 3.14

3.6 Semivolatile Organics Analysis Data Sheet Tentatively

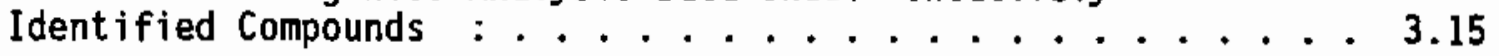

\section{TABLES}

2.1 SST Sample 102-C Water Leach Measurements by ICP Analysis . . . 2.11

2.2 Uranium Correction Factors for Elements Measured

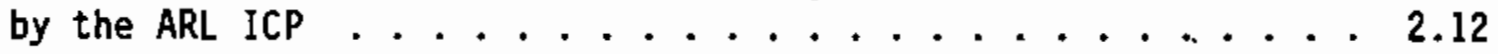

2.3 Anion Analysis of Water Leach from SST Sample 102-C . . . . . 2.13

2.4 EP Toxicity Measurements and Spike Recovery Study by ICP Analysis for SST Sample 102-C . . . . . . . . 2.13

2.5 Results of 5X DiTution on EP Toxicity Measurements by ICP for SST Sample 102-C . . . . . . . . . 2.14

2.6 EP Toxicity Results by ICP Analysis in Units of $\mathrm{mg} / \mathrm{kg}$ for SST Sample 102-C . . . . . . . . . . . 2.15

2.7 Acid Digestion Heasurements and Spike Recovery Study by ICP for SST Sample 102-C (including GFAA Results) . . . . 2.16

2.8 ICP Serial Dilution Results of Acid Digestion of SST Sample 102-C . . . . . . . . . . . 2.17

2.9 Comparison of $\mathrm{KOH}$ and $\mathrm{Na}_{2} \mathrm{O}_{2}$ Fusion of ICP Analysis

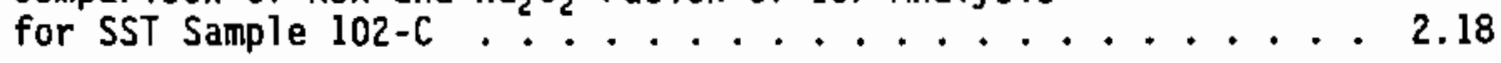

2.10 Sum of Acid Digestion and Fusion of Acid Insoluble Residue for SST Sample 102-C ...................... 


\subsection{INTRODUCTION}

This report describes the analysis of archived single-shell tank (SST) samples 102- $C, 105-C$, and 106- $C$ by the Chemical Measurements Laboratory section of Pacific Northwest Laboratory (PNL). As requested in the Iest Plan for Analysis of Archive Samples of Single-Shell Tank Samples Provided by Westinghouse Hanford Company (Project 13924), the following tasks were performed: 1) organic and inorganic analyses were performed on sample 102-C, 2) radiochemical analyses were performed on samples 105- $C$ and 106-C, and 3 ) the normal paraffin hydrocarbon (NPH) radiochemical and inorganic measurements were performed on a combined sample of 106-C and 102-AX supernate. The Test Plan is included as the Appendix.

The analysis of the SST archive samples involved three types of measurements: inorganic analysis, organic analysis, and radiochemical analysis. This report is divided into five sections, one for each of the measurement categories, a fourth section discussing the NPH study, and the final section addressing radiological exposure measurements. At the end of each section, the objectives for each measurement category, which are bulleted on page 1 of the Test Plan, are addressed.

The tables and figures for Sections 2.0 through 6.0 are at the end of each section. 
$\because$

$\because$ 


\subsection{INORGANIC ANALYSIS}

The sample preparation and percent solids determinations are included in this section, as well as a discussion of the results from the following test methods: water leach, EP Toxicity, acid digestion, fusion, mercury analysis, and total cyanide.

The Test Plan for the SST samples includes duplicate and spike analyses with each of the inorganic test methods to obtain information about reproducibility of these methods and to validate the data generated from the water leach and the EP Toxicity procedures.

To evaluate inorganic -test method performance, the USEPA CLP SOW 787 criteria for sensitivity, reproducibility of duplicate analyses, and spike recovery were applied to the test results, although the criteria are only applicable for acid-digested soil and water samples. For reference purposes only, the following SOW 787 criteria are used throughout this report:

- Spike sample analysis--the acceptance range for spike recovery is $75 \%$ to $125 \%$.

- Duplicate sample analysis--the relative percent differences (RPD) between duplicate sample analyses must be within $\pm 20 \%$ if the results of the element analyzed are at least five times the procedure detection limit. RPD is defined as $((S-D) /[(S+D) / 2]\}$ $X 100$, where $S=$ sample value and $D=$ duplicate value.

- ICP serial dilution--if the element analyzed is at least 50 times the instrument detection limit, a five-fold difution must agree with the original analysis to within a percent difference of $\pm 10 \%$. Percent difference is defined as [(I-D) / I] $X 100$, where $I=$ initial solution value and $D=$ diluted solution value.

\subsection{TEST METHODS, RESULTS, AND SIGNIFICANCE}

\subsubsection{Sample Preparation}

Sol id samples from SST 102-C, SST 105-C, and 106-C were crushed, sieved, and homogenized as illustrated in Figure $l$ of the Test $\mathrm{Pl}$ an (see Appendix). (Sample 106-C was previously prepared for earlier tests using a similar process.) In accordance with the Test Plan, sample 102-C was prepared for analysis of inorganic cations by inductively coupled plasma-atomic emission 
spectroscopy (ICP/AES, hereafter referred to simply as ICP), for inorganic anions by ion chromatography (IC), and for total organic carbon (TOC) and total inorganic carbon (TIC); also, SST samples $105-C$ and 106-C were fused for radiochemical analysis and measurement of inorganic cations by ICP.

\subsubsection{Percent Solids Determination}

The percent solids content of two 1 - to $1.5-\mathrm{g}$ portions of SST 102-C were determined by comparing the sample weight before and after drying at $103^{\circ} \mathrm{C}$ to $105^{\circ} \mathrm{C}$, as illustrated in Figure 2 of the Test Plan (see Appendix). The result, defined as [(sample dry weight/sample wet weight) $X 100]$, was approximately $94 \%$ solids for both samples.

\subsubsection{Water Leach}

Shown in Figure 3 of the Test Plan (see Appendix), the water leach procedure involved leaching the samples with deionized water (DIW) in an ultrasonic bath for $1 \mathrm{~h}$, filtering the solution through $0.45-\mu \mathrm{m}$ filters, and analyzing the filtered solutions. The ICP results for 38 elements are given in Table 2.1. The values in the columns labeled "Raw ICP $(\mu \mathrm{g} / \mathrm{mL})$ " are the observed elemental concentrations; the values in the columns labeled "Corr. $(\mu \mathrm{g} / \mathrm{mL}) "$ are the observed elemental concentrations corrected for spectral interferences from $U$ and $A$. Elements that are followed by an (e) have low sensitivity by ICP analysis and also require significant spectral corrections due to the presence of $U$ and $A T$. Table 2.2 shows the effects of spectral interferences from a standard $U$ solution on elements analyzed by the ICP. Note that $U$ significantly interferes with the $\mathrm{Se}, \mathrm{Sb}$, and $T 1$ analyses and, to a lesser degree, the $S i$ and $P$ analyses. The data in Table 2.1 demonstrate this clearly, since the raw ICP results for $S b$, Se, and $T 1$ are positive, whereas the values after correction for $U$ and $A l$ interference are negative. For those elements that have significant spectral interferences.by ICP analysis, analysis by graphite furnace atomic absorption (GFAA) may be required. Note that for most elements the RPD is considerably larger than the $\pm 20 \%$ that is considered acceptable according to the Contract Laboratory Program (CLP) protocol. As discussed in Section 2.2, dissolution of these matrices in water will yield erratic results, which is reflected in these data. 
The IC, TOC, and TIC results are presented in Table 2.3. The low spike recovery for $\mathrm{Cl}$ and $\mathrm{PO}_{4}$ cannot be readily explained. The average orthophosphate value of $1030 \mathrm{mg} / \mathrm{kg}$ from IC analysis of samples 1 and 2 is $17 \%$ lower than the ICP P value of $405 \mathrm{mg} / \mathrm{kg}$, if the latter is assumed to be all orthophosphate $(1242 \mathrm{mg} / \mathrm{kg})$. Total $P$ is measured by ICP, whereas IC is specific for orthophosphate ion. If some of the $P$ were present in other ionic forms, this might explain the higher ICP result.

\section{1 .4 EP Toxicity}

A modified EP Toxicity study was performed on duplicate $10 \mathrm{~g}$ portions of SST archive sample 102-C according to EPA SW 846, Method 1310, as shown in Figure 4 of the Test Plan (see Appendix). The study consisted of a spike recovery study for nine elements on the EP Toxicity list; analys is of 10-mL aliquots of the filtered solutions after leaching with dilute acetic acid; and analysis of $5 X$ serial dilutions of the aliquots.

The results of the spike recovery study, measured by ICP analysis with the use of duplicate $10 \mathrm{~g}$ s samples, are given in Table 2.4. Spike recovery values were anomalously high for $\mathrm{Cr}$, Se, and $\mathrm{Tl}$. Poor ICP sensitivity and significant spectral correction due to $U$ interference may have been the cause for the high values for Se and Tl; GFAA analysis may be required for these elements. The reason for the high $\mathrm{Cr}$ recovery is unknown. EP Toxicity measurement results performed by ICP methods on both the original solutions and on $5 X$ serial dilutions are presented in Table 2.5. It is clear from the percent difference results for the undiluted and $5 X$ diluted measurements for the duplicate samples that the reproducibility of the serial dilution values is within acceptable limits for most of the elements. If acetic acid affects the ICP results, greater differences would be expected between the two solutions since the diluted sample contains only one-fifth the acetic acid concentration $(0.02 \mathrm{M}$ versus $0.1 \mathrm{M})$. The fact that the results of the $5 \mathrm{X}$ serial dilution are within the acceptance limits indicates that acetic acid concentration does not significantly affect the ICP results.

Table 2.6 also contains the EP Toxicity results for SST sample 102-C. However, the results are given in units of $\mathrm{mg} / \mathrm{kg}$ so that the results can be directly compared with those of the samples prepared by acid digestion and by 
fusion. Note that for many elements the RPD between duplicate sample analyses is larger than the $\pm 20 \%$ control limit for. ICP analysis method 6010 in EPA SW 846. As discussed in Section 2.2, dissolution of these matrices in di7ute acetic acid can yield erratic results, which is reflected in these data.

\subsubsection{Acid Digestion}

The acid digestion and filtration portion of the sample preparation was performed in the hot cell according to SOW 787 and required $1-$ to $1.5-\mathrm{g}$ samples of SST 102-C. Since the sample preparation adhered to the CLP method as closely as was reasonably possible in the hot cell, no further discussion of the sample preparation for the acid digestion method is given in this report. This acid digestion method was selected over the SW 846 method since SW 846 required the solutions to be evaporated without boiling to near dryness, which would significantiy increase the sample preparation time.

The ICP and GFAA results given in Table 2.7 show that the RPDs between duplicate analyses are within $\pm 20 \%$ except for the elements $\mathrm{B}, \mathrm{Cd}, \mathrm{Cu}, \mathrm{K}, \mathrm{Si}$, $\mathrm{Tl}$, and $\mathrm{V}$. Note that all of these elements (except $\mathrm{Si}$ ) are at or near the detection limit of the ICP analysis. During the acid digestion procedure, silicates partially dehydrate to insoluble $\mathrm{SiO}_{2}$. Since this dehydration is not reproducible, the Si results may be erratic. However, $\mathrm{Si}$ is currently not identified as an EPA priority pollutant.

Aiso, five of the elements with poor spike recovery that are listed in Table 2.7 (i.e., As, $\mathrm{P}, \mathrm{Pb}, \mathrm{Sb}$, and $\mathrm{Tl}$ ) are noted as having poor instrument sensitivity and significant spectral interference from $U$ and $A 1$ when analyzed by ICP. Although these corrections are a significant percentage of the "raw" intensity, the observed values agree reasonably well with the GFAA results for As and Pb. A comparison of the ICP and GFAA results show that $\mathrm{Sb}$, Se, and $\mathrm{Tl}$ cannot be analyzed with good accuracy by ICP due to poor ICP sensiti$v i t y$ and large spectral interference from $U$. These elements are candidates for GFAA analysis.

Results of serial dilution measurements on selected elements from the acid-digested samples are given in Table 2.8. The percent difference values for the serial dilution results are much less than $\pm 10 \%$, and thus chemical or physical interference effects would not be expected from the matrix. 


\subsubsection{Fusion: ICP Analysis}

As shown in Figure 8 of the Test Plan (see Appendix), portions of SST sample 102-C were fused in the hot cell with $\mathrm{KOH}$ in a $\mathrm{Ni}$ metal crucible; a second fusion was also performed with $\mathrm{Na}_{2} \mathrm{O}_{2}$ in a $\mathrm{Zr}$ metal crucible. After cooling, the fused mixtures were dissolved in DIW. The solutions were transferred into volumetric flasks, acidified with $\mathrm{HCl}$, diluted to volume, and aliquots were removed from the hot cell for ICP analyses. The ICP analyses of the $\mathrm{KOH} / \mathrm{Ni}$ and the $\mathrm{Na}_{2} \mathrm{O}_{2} / \mathrm{Zr}$ fusions are presented in Table 2.9. The RPD in the ICP results between the two fusion methods is within $\pm 20 \%$, except for cations that are near the detection limit of the ICP method or for cases that require significant spectral corrections due to interferences from $U$ and $A]$.

Also, the precipitates filtered from the acid digestion of samples 1 and 2 from SST sample 102-C were fused, as shown in Figure 8 of the Test Plan (see Appendix), and analyzed. A summation of the results for the acidsoluble and acid-insoluble fused portions are given in Table 2.10. The major acid-insoluble constituents in these samples are $\mathrm{Al}, \mathrm{Ca}, \mathrm{Fe}, \mathrm{Mg}$, and $\mathrm{Si}$, indicating the presence of some type of zeolite or acid-insoluble mineral compound in the waste tank sample.

Since SST samples $105-C$ and $106-C$ were fused and dissolved for radiochemical analysis (see Section 4.0), ICP analyses were also performed. The results for these samples, as well as SST sample 102-C, are tabulated in Table 2.11. The three tank samples show significant differences in chemical composition of the major constituents, which is expected.

\subsubsection{Comparison of Water Leach, EP Toxicity, Acid Digestion, and Total Fusion ICP Analysis Results}

Analytical results from the four methods used for sample preparation of archive SST sample 102-C for inorganic constituents are given in Table 2.12; these are reported in units of $\mathrm{mg} / \mathrm{kg}$ to allow direct comparison. As mentioned in Section 2.1.6, the acid-insoluble portion of the sample was also fused and analyzed. Thus, the sum of "Acid Digestion" and "Acid Insol Fusion" should be equal to the "Fusion" values, provided that none of the acid-insoluble precipitate was lost during the transfer of the filter to the metal crucible used for fusion of the sample. 
Note: A $0.45-\mu m$ membrane disposable plastic filtration apparatus

was used to filter the acid digestion solution in the hot cell.

When the filtration apparatus was taken apart in the hot cell, some of the precipitate could have been lost. Therefore, the acidinsoluble results should be used for indication purposes only.

The Al result for the water leach sample is higher than the $A 1$ value for the EP Toxicity solution. The PH of the EP Toxicity leachate prior to acetic acid addition was 11.4. The $\mathrm{pH}$ of the water leach was not measured. However, if it is assumed that the $\mathrm{pH}$ of the water leach was similar to that measured for the EP Toxicity method, some of the AT should be in the form of a soluble aluminate. Since the final $\mathrm{pH}$ for the EP Toxicity method is adjusted to 5.0, all of the Al should be precipitated as hydroxide.

It is surprising that $P$ and $Z r$ were lower for the EP Toxicity sample than for the water leach sample. However, it was observed that the water leach samples that were filtered through the $0.45-\mu \mathrm{m}$ filter coagulated a flocculent light-reddish precipitate when the solution was left undisturbed over the weekend. One plausible explanation is that the $\mathrm{Zr}$ and $\mathrm{P}$ may have existed as a colloidal suspension in the water leach sample. If so, when the $\mathrm{pH}$ was adjusted to 5.0 with acetic acid according to the EP Toxicity method, the colloid coprecipitated when the aluminate ion was converted to $\mathrm{Al}(\mathrm{OH})_{3}$, thus significantly reducing the concentration of the $Z r$ and $P$ in solution.

\subsubsection{Mercury Analysis by Cold Vapor Atomic Absorption (CVAA)}

The $\mathrm{Hg}$ analysis was performed using CLP SOW 787 method 245.5 with some modification, as described in Section 2.2. The $\mathrm{Hg}$ was determined on a Perkin-Elmer atomic absorption unit in an open-faced hood. The $\mathrm{Hg}$ values for the duplicate analyses were $0.568 \mathrm{mg} / \mathrm{kg}$ and $0.572 \mathrm{mg} / \mathrm{kg}$, giving a RPD of 2.4\%. A third sample weighing $1.3347 \mathrm{~g}$ was spiked with $1.5 \mu \mathrm{g} \mathrm{of} \mathrm{Hg}$; the spiked sample was treated in the same manner as the other two samples. The spike recovery was $97 \%$.

\subsubsection{Iotal Cyanide}

The total cyanide procedure (SOW 797 method 335.2) was modified by substituting $\mathrm{MgSO}_{4}$ for $\mathrm{MgCl}_{2}$ as the catalyst for decomposition of the ferrocyanide complex. It was found that if $\mathrm{l} \mathrm{g}$ of $\mathrm{NaNO}_{3}$ was added to the 
cyanide distillation apparatus containing $\mathrm{MgCT}_{2}$, very poor cyanide recovery was observed. When $\mathrm{MgSO}_{4}$ was substituted for $\mathrm{MgCl}_{2}$, the cyanide recovery improved dramatically. The cyanide values reported for duplicate analyses are $0.92 \mathrm{mg} / \mathrm{kg}$ and $1.10 \mathrm{mg} / \mathrm{kg}$, giving a RPD of $17.8 \%$. These values are significantly lower than the EPA reactivity limit of $250 \mathrm{mg} / \mathrm{kg}$. TotaT cyanide spike recovery was $87 \%$.

\subsection{PROBLEM AREAS AND CORRECTIVE ACTIONS}

\subsubsection{ICP SpectraT Corrections}

CLP protocol requires that spectral corrections be applied to all elements to obtain background and interelement corrected results. The ICP analyses performed on the SST samples deviated from these requirements. The Applied Research Laboratory (ARL) ICP used to analyze these samples determines 12 of the 38 elements with the sequential spectrometer. The analysis time for each element on the sequential system is comparable to the analyses time for all 26 elements on the simultaneous system. Since one third of the required elements were determined sequentially, the time required to scan all of the element combinations to determine spectral correction factors would be prohibitive; therefore, no spectral correction factors were entered into any of the calculation programs. For the analysis results in this report, spectral corrections from $U$ and $A 1$ were calculated by hand and the corrections applied to each analysis element.

\subsubsection{Poor Reproducjbility from Water Leach and EP Toxicity Methods}

The RPD values calculated from the water leach and EP Toxicity data are outside the control 1 imit of $\pm 20 \%$ for most of the elements. This is true even though the concentrations for several of the elements are a factor of 5 greater than the ICP detection limit. If the RPD values for the duplicate sample analyses on the water leach and EP Toxicity measurements are compared with those for the acid digestion and fusion methods, the values for the latter two procedures are significantly better. This is because when samples are leached with water, or with dilute acetic acid as in the EP Toxicity method, the amount of a given element brought into solution can be highty 
variable due to small variations in the acidity or alkalinity of the sample matrix. This is not the case for the more robust acid digestion or fusion techniques.

\subsubsection{Modification to CVAA Method}

When a significant concentration of $\mathrm{Hg}(\mathrm{i} . \mathrm{e} .,>10 \mu \mathrm{g})$ was reduced to metal with $\mathrm{SnCl}_{2}$ and air sparged into a $\mathrm{KMnO}_{4}$ solution, a significant portion of the elemental $\mathrm{Hg}$ was trapped in the fritted cylinder in the trap solution. once trapped, the $\mathrm{Hg}$ could not be quantitatively recovered. The CVAA $\mathrm{Hg}$ method was modified in the following manner for the SST sample analyses.

1. After digestion of the sample with $\mathrm{KMnO}_{4}$, a portion of the sample was removed from the hot cell.

2. A measured aliquot of the $\mathrm{KMnO}_{4}$-treated sample was pipetted into the CVAA apparatus and the $\mathrm{Hg}$ was reduced with $\mathrm{SnCl}_{2}$ and analyzed.

3. The $\mathrm{Hg}$ in the sample was calculated using the dilution of the sample aliquot analyzed and the volume of the solution in No. 1.

\subsection{TEST PLAN OBJECTIVES}

\subsubsection{To Determine if There Are Problems with Employing the Various. Analytical Methods on the Test Samples}

No major difficulties were encountered in the water leach, EP Toxicity, acid digestion, or fusion procedures for inorganic analysis. It should be recognized that the reproducibility of water Teach and EP Toxicity procedures will be very poor on samples where the major metal ions in the basic sludge are multivalent metal ions, since several of these ions would be precipitated as basic hydroxides. Since most of the multivalent metal ions are not soluble in basic or slightly acidic solution, good reproducibility would not be expected for these analyses. Since a significant portion of SST sample 102-C is $\mathrm{Al}, \mathrm{Ca}, \mathrm{Fe}, \mathrm{Mn}, \mathrm{Ni}, \mathrm{U}$, and $\mathrm{Si}$, the reproducibility of duplicate analyses for these elements is expected to be worse for water leach or EP Toxicity samples than for acid-digested samples. This was substantiated by the analyses that were performed.

An interesting observation from the results presented in Table 2.12 is that several of the metal ions that form insoluble hydroxides are higher in 
the water leach than in the EP Toxicity sample. When the acid waste from the separation process in the 200 Area chemical processing facilities was neutralized with $\mathrm{NaOH}$, the wastes were made basic to prevent corrosion of the steel SSTs. If the water leach of SST sample 102-C has a starting $\mathrm{pH}>11$, some of the Al will dissolve to form aluminate ions. This is indicated by the high $A 1$ content of the water leach sample. Aluminum is amphoteric; therefore, when the solution in the EP Toxicity procedure is neutralized with acetic acid to a $\mathrm{pH}$ of 5.0 , the soluble aluminate witl be neutralized to a gelatinous $\mathrm{Al}(\mathrm{OH})_{3}$ precipitate, which will coprecipitate any colloidal metal oxides or hydroxides dissolved by the initial water leach in the EP Toxicity procedure.

\subsubsection{To Determine if the ICP Has Sufficient Sensitivity for Analysis of of EP Toxicity Metal Ions (excluding $\mathrm{Ha}$ )}

For the EP Toxicity metal jons As, Pb, and Se, ICP has poor sensitivity, and significant corrections are required for $U$ interference. Elements Se and As require such large spectral corrections for $A T$ and $U$ that these results are not considered reliable at the reported concentration levels. Also, the data for the EP Toxicity elements in Table 2.12 for SST archive sample 102-C indicate that the $\mathrm{Pb}$ and total $\mathrm{Cr}$ could exceed the EP Toxicity threshold, making $\mathrm{Pb}$ analysis by ICP questionable. The toxicity threshold for both elements is $100 \mathrm{mg} / \mathrm{kg}$ based on the acjd-digested sample criteria.

ICP sensitivity would be sufficient to measure all of the EP Toxicity metal ions except Se, if the $U$ content in SST sample 102-C were lower. The $U$ concentrations for the duplicate analyses after extraction by the EP Toxicity procedure were 430 and $356 \mu \mathrm{g} / \mathrm{mL}$ (Table 2.5). Even this low U concentration, however, requires spectra] correction to $\mathrm{As}, \mathrm{Cr}, \mathrm{Pb}, \mathrm{Se}$, and $\mathrm{Ag}$ of between 50 and $90 \%$ of the "raw" intensities. Many of these elements wi17 require GFAA analysis for EP Toxicity when the samples contain U. Table 2.13 is a summary of this objective.

\subsubsection{To Determine Which of the 22 EPA Pollutant Metal Ions Can Be Determined by ICP Analysis}

As discussed previously, the ICP has low sensitivity and significant corrections are required due to $U$ interference for $A s, P b$, and $S e$; this is 
also the case for $\mathrm{Sb}$ and $\mathrm{Tl}$. For $\mathrm{Ag}, \mathrm{Be}, \mathrm{Cd}$, and $\mathrm{V}$ (for SST archive sample $102-C)$ spectral corrections in excess of $50 \%$ of the uncorrected ICP values were required. However, due to their high instrument sensitivity, these elements are still considered measurable by ICP. Table 2.14 is a summary of this objective.

\subsubsection{Io Determine if Mercury Can Be Determined by the CVAA Method}

The $\mathrm{Hg}$ analysis was performed in duplicate using CLP SOW 787 method 245.5, with modifications, on a 1.1005- and 1.3118-g sample. Based on the excellent test results (i.e., a RPD of $2.4 \%$ and spike recovery of $97 \%$ ), $\mathrm{Hg}$ can be determined by CVAA. 
TABLE 2.1. SST Sample 102-C Water Leach Measurements by ICP Analysis

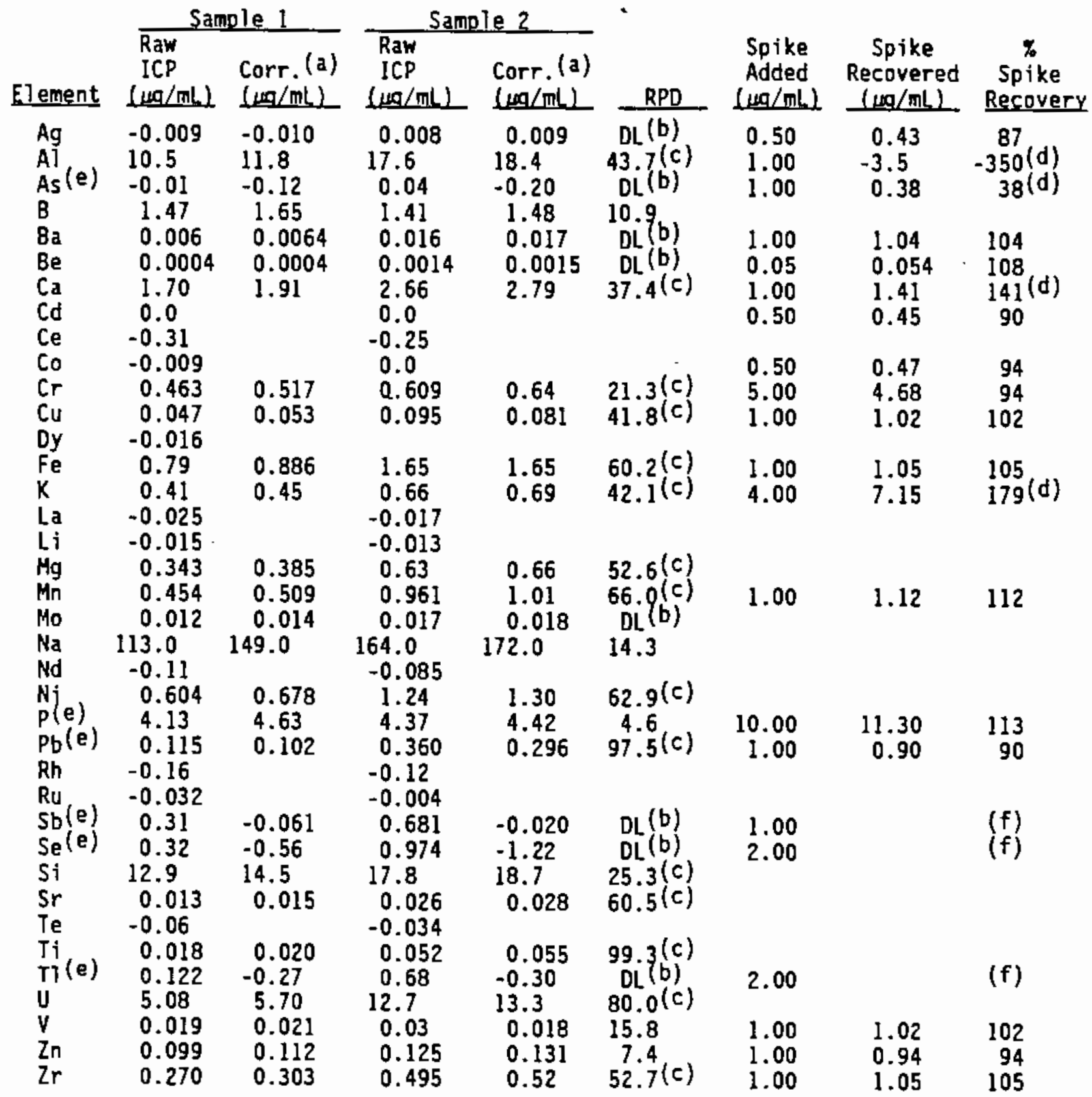

(a) Raw ICP observed results corrected for $U$ \& Al interference.

(b) Values at or near ICP detection limit; defined as $\pm 50 \%$ RSD.

(c) Values exceeding sow 787 control limit of $\pm 20 \%$. Indication purpose only.

(d) Spike recovery exceeds SOW $787 \mathrm{limit}$ of $\pm 25 \%$. Indication purpose oniy.

(e) Elements with poor ICP sensitivity and high U \& Al spectral interference.

(f) Poor sensitivity and interferences render results meaningless. 
TABLE 2.2. Uranium Correction Factors for Elements Measured by the ARL ICP

\begin{tabular}{|c|c|c|c|c|}
\hline $\begin{array}{l}\text { Direct } \\
\text { Reader } \\
\text { Elements } \\
\end{array}$ & Wavelength & 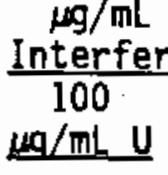 & $\begin{array}{l}\frac{100}{500} \\
\mathrm{Hg} / \mathrm{mL} \mathrm{U}\end{array}$ & $\begin{array}{l}\text { Potential } \\
\text { to Reduce } \\
\text { Interference (a) }\end{array}$ \\
\hline $\begin{array}{l}\mathrm{Al} \\
8 \\
\mathrm{Ba} \\
\mathrm{Ca} \\
\mathrm{Ce} \\
\mathrm{Cr} \\
\mathrm{Dy} \\
\mathrm{Fe} \\
\mathrm{K} \\
\mathrm{La} \\
\mathrm{Li} \\
\mathrm{Mg} \\
\mathrm{Mn} \\
\mathrm{Mo} \\
\mathrm{Na} \\
\mathrm{Nd} \\
\mathrm{Ni} \\
\mathrm{Rh} \\
\mathrm{Ru} \\
\mathrm{Si} \\
\mathrm{Sr} \\
\mathrm{Te} \\
\mathrm{Ti} \\
\mathrm{Zn} \\
\mathrm{Zr}\end{array}$ & $\begin{array}{l}309.270 \\
249.680 \\
455.4 \\
393.370 \\
413.76 \\
267.720 \\
353.170 \\
259.94 \\
766.49 \\
379.480 \\
670.780 \\
279.52 \\
257.610 \\
202.030 \\
589.590 \\
406.110 \\
231.600 \\
343.49 \\
240.270 \\
288.160 \\
407.770 \\
214.280 \\
337.280 \\
213.860 \\
339.200\end{array}$ & $\begin{array}{l}1.07 \\
0.113 \\
0.022 \\
0.005 \\
0.682 \\
0.329 \\
0.0686 \\
0.135 \\
0 . \\
0.085 \\
0.007 \\
0.005 \\
0.043 \\
0.021 \\
0.261 \\
0.361 \\
0.080 \\
0.655 \\
0.240 \\
1.959 \\
0.008 \\
0.154 \\
0.031 \\
0\end{array}$ & $\begin{array}{l}5.08 \\
0.609 \\
0.114 \\
0.101 \\
3.096 \\
1.501 \\
0.322 \\
0.674 \\
-. \\
0.394 \\
0.015 \\
0.033 \\
0.140 \\
0.075 \\
0.089 \\
1.710 \\
0.332 \\
3.034 \\
1.022 \\
5.912 \\
0.062 \\
0.588 \\
0.135 \\
0.024 \\
0.240\end{array}$ & $\begin{array}{c}? \\
\text { Yes } \\
\text { Yes } \\
? \\
\text { Yes } \\
? \\
\text { Yes } \\
\text { Yes } \\
? \\
\text { Yes } \\
\text { Yes } \\
\text { Yes } \\
? \\
\text { Yes } \\
\text { Yes } \\
? \\
\text { Yes } \\
\text { Yes } \\
? \\
? \\
\text { Yes } \\
\text { Yes } \\
\text { Yes } \\
\text { Yes } \\
\text { Yes }\end{array}$ \\
\hline \multicolumn{5}{|c|}{$\begin{array}{l}\text { Sequentia] } \\
\text { Elements }\end{array}$} \\
\hline $\begin{array}{l}\mathrm{Ag} \\
\mathrm{Cu} \\
\mathrm{Be} \\
\mathrm{V} \\
\mathrm{Tl} \\
\mathrm{Co} \\
\mathrm{Pb} \\
\mathrm{Sb} \\
\mathrm{P} \\
\mathrm{Se} \\
\mathrm{As} \\
\mathrm{Cd}\end{array}$ & $\begin{array}{l}328.068 \\
324.754 \\
313.042 \\
292.402 \\
276.787 \\
228.616 \\
220.353 \\
206.833 \\
214.914 \\
196.026 \\
193.696 \\
226.502\end{array}$ & $\begin{array}{c}-- \\
0.145 \\
0.009 \\
0.108 \\
7.777 \\
0.050 \\
0.477 \\
6.210 \\
1.264 \\
17.05 \\
1.911 \\
0.026\end{array}$ & $\begin{array}{c}1.123 \\
0.744 \\
0.044 \\
0.519 \\
37.57 \\
0.240 \\
1.982 \\
33.56 \\
5.057 \\
79.13 \\
6.987 \\
0.039\end{array}$ & $\begin{array}{c}? \\
? \\
? \\
? \\
? \\
? \\
? \\
\text { No } \\
\text { No } \\
\text { No } \\
? \\
\text { Yes }\end{array}$ \\
\hline
\end{tabular}

(a) "Yes" (or "No") indicates there is (or is not) a potential to minimize interference effects by the use of off-peak background correction techniques. "?" indicates the potential is unknown. 
TABLE 2.3. Anion Analysis of Water Leach from SST Sample 102-C

\begin{tabular}{|c|c|c|c|c|c|c|}
\hline Anion & $\begin{array}{l}\text { Sample } 1 \\
\text { (mg/kg) }\end{array}$ & $\begin{array}{l}\text { Sample } 2 \\
(\mathrm{mg} / \mathrm{kg})\end{array}$ & RPD & $\begin{array}{c}\text { 'Spike } \\
\text { Added } \\
(\mathrm{mg} / \mathrm{kg})\end{array}$ & $\begin{array}{c}\text { Spike } \\
\text { Recovered } \\
(\mathrm{mg} / \mathrm{kg}) \\
\end{array}$ & $\begin{array}{l}\% \text { Spike } \\
\text { Recovery }\end{array}$ \\
\hline $\begin{array}{l}\mathrm{F} \\
\mathrm{Cl} \\
\mathrm{NO}_{2} \\
\mathrm{NO}_{3} \\
\mathrm{PO}_{4} \\
\mathrm{SO}_{4}(\mathrm{c}) \\
\mathrm{TIC}(\mathrm{C}) \\
\mathrm{TOC} \text { (c) }\end{array}$ & $\begin{array}{r}301 \\
388 \\
3,400 \\
9,900 \\
1,140 \\
835 \\
3,900 \\
262\end{array}$ & $\begin{array}{r}260 \\
342 \\
3,000 \\
9,690 \\
910 \\
814 \\
3,280 \\
284\end{array}$ & $\begin{array}{c}14.6 \\
12.6 \\
12.5 \\
2.1 \\
22.4(b) \\
2.6 \\
17.2 \\
8.1\end{array}$ & $\begin{array}{r}200 \\
370 \\
13,400 \\
1,500 \\
1,150 \\
2,860\end{array}$ & $\begin{array}{r}190 \\
185 \\
14,600 \\
1,105 \\
805 \\
2,586\end{array}$ & $\begin{array}{l}95 \\
50(a) \\
110 \\
74(a) \\
70(a) \\
90\end{array}$ \\
\hline
\end{tabular}

(a) Anion with spike recovery not within the $\pm 25 \%$ defined by the Test Plan.

(b) Values exceeding Sow 787 control limit of $\pm 20 \%$. Indication purpose only.

(c) TIC = Total inorganic carbon; TOC = Total organic carbon.

TABLE 2.4. EP Toxicity Measurements and Spike Recovery Study by ICP Analysis for SST Sample I02-C

\begin{tabular}{|c|c|c|c|c|c|c|}
\hline \multirow[b]{2}{*}{\begin{tabular}{c}
\multicolumn{1}{c}{ EP } \\
Toxicity \\
Element \\
\end{tabular}} & \multicolumn{3}{|c|}{ EP Toxicity Measurements } & \multicolumn{3}{|c|}{ Spike Recovery Measurements } \\
\hline & $\begin{array}{l}\text { Sample } 1 \\
(\mu \mathrm{g} / \mathrm{mL})\end{array}$ & $\begin{array}{l}\text { Sample } 2 \\
\text { (ua/mL) }\end{array}$ & RPD & $\begin{array}{l}\text { Spike } \\
\text { Added } \\
(\mu \mathrm{g} / \mathrm{mL})\end{array}$ & $\begin{array}{c}\text { Spike } \\
\text { Recovered } \\
(\mu \mathrm{g} / \mathrm{mL})\end{array}$ & $\begin{array}{l}\text { \% Spike } \\
\text { Recovery }\end{array}$ \\
\hline $\begin{array}{l}\mathrm{Ag} \\
\mathrm{As} \\
\mathrm{Ba} \\
\mathrm{Cd} \\
\mathrm{Cr} \\
\mathrm{Hg}(\mathrm{C}) \\
\mathrm{Ni} \\
\mathrm{Pb} \\
\mathrm{Se} \\
\mathrm{Tl}\end{array}$ & $\begin{array}{l}0.003 \\
1.63 \\
0.018 \\
0.009 \\
1.46 \\
0.0066 \\
0.206 \\
0.07 \\
0.5 \\
0.31\end{array}$ & $\begin{array}{l}0.17 \\
2.39 \\
0.02 \\
0.068 \\
1.74 \\
0.0063 \\
0.23 \\
0.54 \\
8.6 \\
3.1\end{array}$ & $\begin{array}{c}193(a) \\
37.8(a) \\
10,5 \\
153(a) \\
17.5 \\
4.7 \\
11 \\
154(a) \\
178(a) \\
164(a)\end{array}$ & $\begin{array}{l}5.0 \\
5.0 \\
5.0 \\
1.0 \\
5.0\end{array}$ & $\begin{array}{l}4.63 \\
4.42 \\
4.96 \\
0.99 \\
7.25\end{array}$ & $\begin{array}{c}93 \\
88 \\
99 \\
99 \\
145(b) \\
93 \\
82 \\
390(b) \\
121\end{array}$ \\
\hline
\end{tabular}

(a) Values exceed SOW 787 limit of $\pm 20 \%$. Indication purposes only.

(b) Spike recovery exceed SOW 787 limit of $\pm 25 \%$. Indication purposes only.

(c) Hg analyses performed by CVAA. 

TABLE 2.5. Results of $5 X$ Dilution on EP Toxicity Measurements by
ICP for SST Sample 102-C

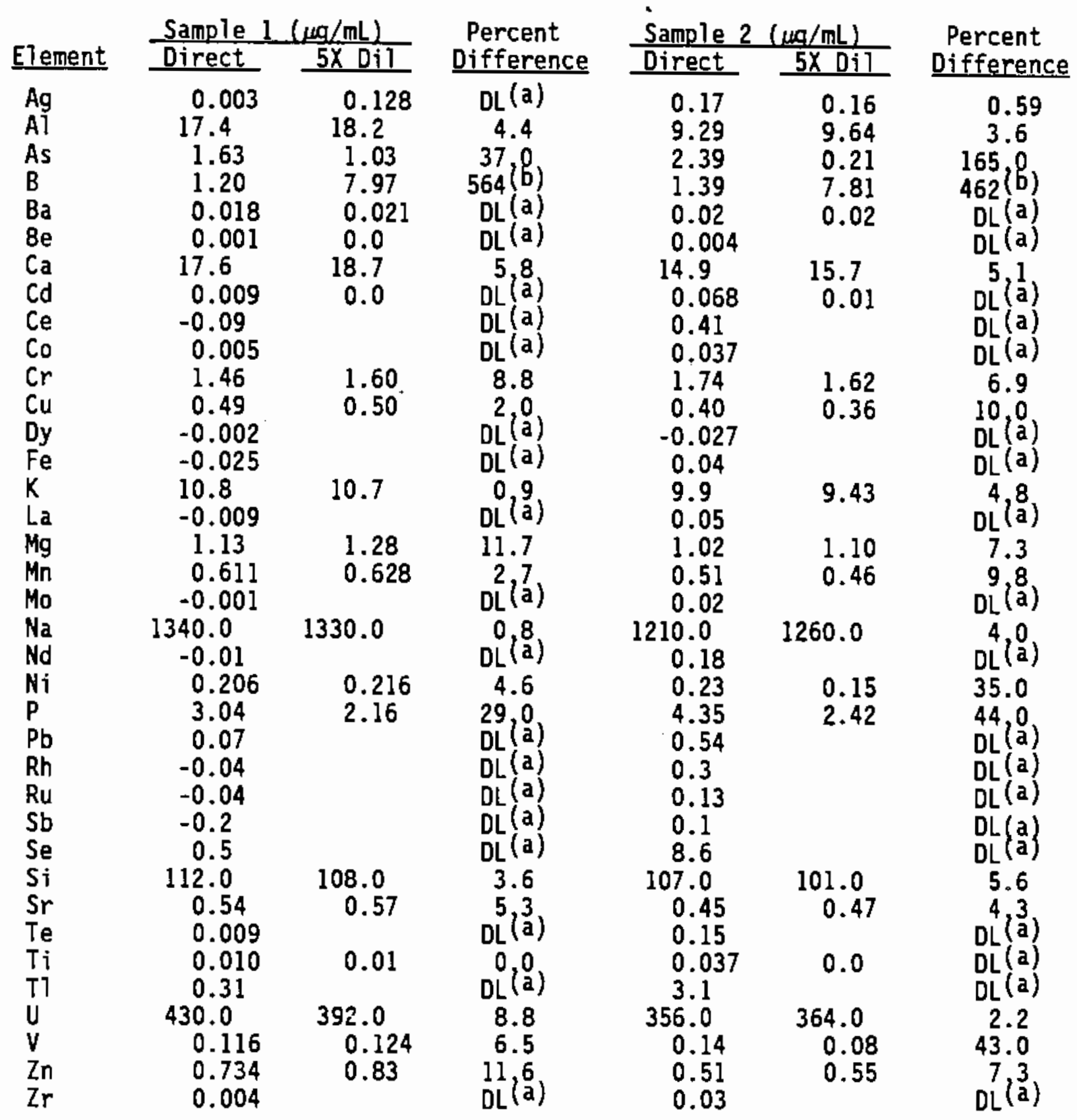

(a) Values at or near ICP detection 1 imit defined as $\pm 50 \%$ RPD.

(b) Reason for large percent difference is unknown, possible borosilicate glass contamination. 
TABLE_2.6. EP Toxicity Results by ICP Analysis in Units of $\mathrm{mg} / \mathrm{kg}$ for SST Sample 102-C

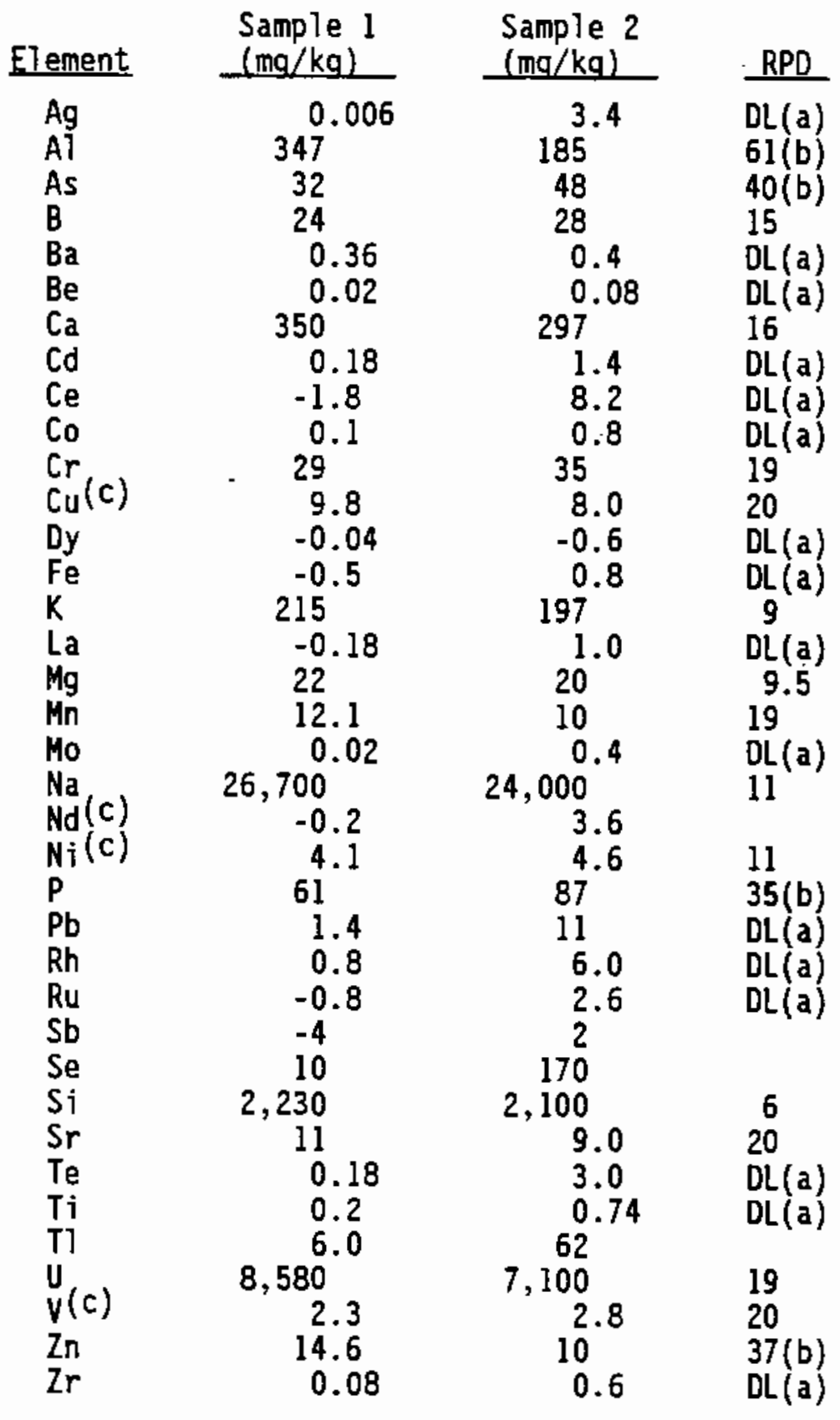

(a) Values at or near ICP detection limit; defined as $\pm 50 \%$ RSD.

(b) Values exceeding SOW 787 control limit of $\pm 20 \%$. Indication purpose only.

(c) Elements where the $U$ correction is greater than $50 \%$ of the ICP raw data. 
IABLE 2.7. Acid Digestion Measurements and Spike Recovery Study by ICP for SST Sample 102-C (including, GFAA Results)

\begin{tabular}{|c|c|c|c|c|c|c|}
\hline Element & $\begin{array}{l}\text { Sample } 1 \\
(\mathrm{mg} / \mathrm{kg})\end{array}$ & $\begin{array}{l}\text { Sample } 2 \\
(\mathrm{mg} / \mathrm{kg})^{2}\end{array}$ & RPD & $\begin{array}{l}\text { Spike } \\
\text { Added }\end{array}$ & $\begin{array}{c}\text { Spike } \\
\text { Recovered }\end{array}$ & $\begin{array}{l}\text { \% Spike } \\
\text { Recovery }\end{array}$ \\
\hline $\mathrm{Ag}(\mathrm{a}, \mathrm{b})$ & 26.1 & 27 & 3 & 92.6 & 89.8 & 97 \\
\hline$A s(a)$ & $\begin{array}{r}132,000 \\
39\end{array}$ & $\begin{array}{r}158,000 \\
42\end{array}$ & 7 & 370 & 279 & 75 \\
\hline $\begin{array}{l}\mathrm{B} \\
\mathrm{Ba}(b)\end{array}$ & $\begin{array}{c}200 \\
37.2\end{array}$ & $\begin{array}{l}70 \\
39.6\end{array}$ & $\begin{array}{c}96(c) \\
6\end{array}$ & 370 & 274 & 74 (d) \\
\hline $\mathrm{Be}(a, b)$ & 2.33 & 2.78 & 18 & 9.3 & 9.8 & 106 \\
\hline $\begin{array}{l}C_{a} \\
C^{\prime}(a, b) \\
C_{0}(a)\end{array}$ & $\begin{array}{r}1,810 \\
8.56 \\
-0.8\end{array}$ & $\begin{array}{r}2,000 \\
12.7 \\
-2.1\end{array}$ & $\begin{array}{l}10 \\
39(c)\end{array}$ & $\begin{array}{r}1,851 \\
92.6 \\
92.6\end{array}$ & $\begin{array}{l}2,040 \\
91.8 \\
95\end{array}$ & $\begin{array}{r}110 \\
99 \\
102\end{array}$ \\
\hline $\begin{array}{l}C r(a) \\
C u(a)\end{array}$ & $\begin{array}{l}243 \\
253\end{array}$ & $\begin{array}{l}248 \\
197\end{array}$ & ${ }_{25}^{2}(\mathrm{c})$ & 2,780 & 2,890 & 104 (f) \\
\hline $\mathrm{Fe}_{\mathrm{g}}(\mathrm{a})$ & 10,290 & 10,950 & 6 & & & \\
\hline$k(a)$ & 330 & $\begin{array}{l}463 \\
632\end{array}$ & $33(c)$ & 185 & 36 & 19 (d) \\
\hline $\begin{array}{l}\mathrm{Mg}(a) \\
M n(a)\end{array}$ & $\begin{array}{r}580 \\
1.950\end{array}$ & $\begin{array}{r}632 \\
2.070\end{array}$ & $\begin{array}{l}9 \\
6\end{array}$ & 370 & 395 & 107 \\
\hline $\begin{array}{l}\mathrm{Na}(\mathrm{a}) \\
\mathrm{Ni}(\mathrm{a})\end{array}$ & $\begin{array}{r}34,050 \\
2,452\end{array}$ & $\begin{array}{r}34,490 \\
2,477\end{array}$ & 1 & & & . \\
\hline & 1,190 & 1,250 & 5 & 1,970 & & (e) \\
\hline $\begin{array}{l}\mathrm{Pb}(\mathrm{a}) \\
\mathrm{Sb}(\mathrm{a})\end{array}$ & $\begin{array}{r}637 \\
-160\end{array}$ & $\begin{array}{r}683 \\
-156\end{array}$ & 9 & $\begin{array}{r}556 \\
93\end{array}$ & 395 & $\begin{array}{l}71 \text { (d) } \\
-- \text { (d) }\end{array}$ \\
\hline $\begin{array}{l}\mathrm{Se}^{(a)} \\
\mathrm{Si}^{2}\end{array}$ & $\begin{array}{r}160 \\
1,245\end{array}$ & $\begin{array}{l}135 \\
968\end{array}$ & $\begin{array}{l}17 \\
25(c)\end{array}$ & & & \\
\hline $\mathrm{Sr}$ & $\begin{array}{r}39.5 \\
936\end{array}$ & $\begin{array}{r}40.7 \\
1.044\end{array}$ & 3 & 185 & 200 & 108 \\
\hline $\mathrm{T} 1(\mathrm{a})$ & 51 & $\begin{array}{r}1,044 \\
38\end{array}$ & 29 (c) & 370 & 143 & 39 \\
\hline & 21,300 & 21,300 & 0,5 & & & \\
\hline $\begin{array}{l}V(a, b) \\
Z_{n}(a) \\
Z r\end{array}$ & $\begin{array}{r}20 \\
222 \\
317\end{array}$ & $\begin{array}{r}25 \\
186 \\
356\end{array}$ & $\begin{array}{l}22(c) \\
18 \\
12\end{array}$ & $\begin{array}{r}93 \\
93 \\
185\end{array}$ & $\begin{array}{r}100 \\
56\end{array}$ & $\begin{array}{l}108 \\
60 \\
-(f)\end{array}$ \\
\hline & & & & 100 & & \\
\hline
\end{tabular}

\section{GRAPHITE FURNACE ATOMIC ABSORPTION RESULTS}

As $=95 \mathrm{mg} / \mathrm{kg} \quad \mathrm{Pb}=780 \mathrm{mg} / \mathrm{kg} \quad \mathrm{Sb}=<30 \mathrm{mg} / \mathrm{kg}$

Se $=<30 \mathrm{mg} / \mathrm{kg} \quad \mathrm{Tl}=<1 \mathrm{mg} / \mathrm{kg}$

(Note: No spike recoveries performed by GFAA)

(a) EPA pollutant metal ions.

(b) Elements where the $U$ correction is greater than $50 \%$ of the ICP raw data.

(c) Values exceeding SOW 787 control limit of $\pm 20 \%$. Indication purpose onty.

(d) Spike recoveries exceeding SOW 787 control 1 imit of $\pm 25 \%$.

(e) $\mathrm{Zr}$ probably precipitated as a zirconium phosphate compound.

(f) Cu and $P$ channel lost during spike analyses. 
TABLE 2.8. ICP Serial Dilution Results of Acid Digestion of SST Sample 102-C

\begin{tabular}{ccccccc} 
Element & $\begin{array}{c}5 \times \mathrm{Dil} \\
(\mu \mathrm{g} / \mathrm{mL})\end{array}$ & $\begin{array}{c}25 \times \mathrm{Dil} \\
(\mu \mathrm{\mu g} / \mathrm{mL})\end{array}$ & $\begin{array}{c}\text { Percent } \\
\text { Difference }\end{array}$ & $\begin{array}{c}5 \times \mathrm{Dil} \\
(\mu \mathrm{\mu} / \mathrm{mL})\end{array}$ & $\begin{array}{c}25 \times \mathrm{Dil} \\
(\mu \mathrm{g} / \mathrm{mL})\end{array}$ & $\begin{array}{c}\text { Percent } \\
\text { Difference }\end{array}$ \\
\cline { 1 - 3 } & 678 & 695 & 2.5 & 684 & 694 & 1.5 \\
$\mathrm{Aa}$ & 9.30 & 9.75 & 4.8 & 8.63 & 8.95 & 3.7 \\
$\mathrm{Fe}$ & 52.9 & 53.9 & 1.9 & 47.3 & 47.9 & 1.3 \\
$\mathrm{Mg}$ & 2.98 & 3.06 & 2.7 & 2.73 & 2.78 & 1.8 \\
$\mathrm{Mn}$ & 10.0 & 10.2 & 2.0 & 8.94 & 9.03 & 1.0 \\
$\mathrm{Na}$ & 175 & 170 & 2.3 & 149 & 150 & 0.7 \\
$\mathrm{Ni}$ & 12.6 & 12.9 & 2.3 & 10.7 & 10.9 & 1.9 \\
$\mathrm{Ti}$ & 4.81 & 4.86 & 1.0 & 4.51 & 4.55 & 0.9 \\
$\mathrm{U}$ & 110 & 109 & 0.9 & 92 & 90 & 2.2 \\
$\mathrm{Zn}$ & 1.14 & 1.14 & 0.0 & 0.804 & 0.780 & 3.0 \\
$\mathrm{Zr}$ & 1.63 & 1.68 & 3.1 & 1.54 & 1.54 & 0.0
\end{tabular}

NOTE: Original fusion solution required a $5 X$ dilution in order to $\mathrm{place}$ the element concentrations with the calibrated ranges. The dilution study was performed by diluting this $5 X$ solution another 5 fold. 
IABLE 2.9. Comparison of $\mathrm{KOH}$ and $\mathrm{Na}_{2} \mathrm{O}_{2}$ Fusion of ICP Analysis for SST Sample 102-C

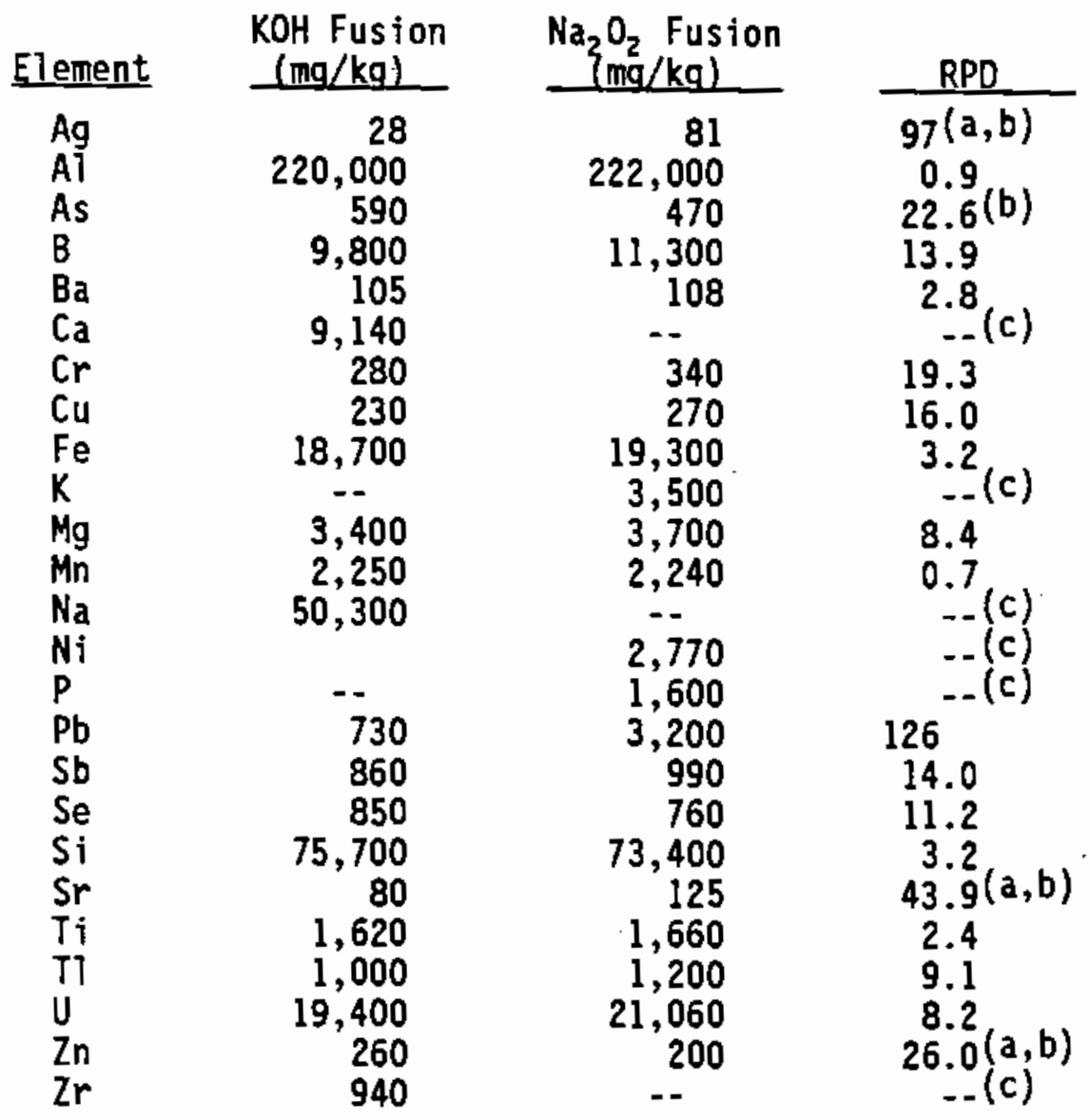
(a) Elements concentration is less than $5 \mathrm{X}$ the ICP detection 7 imit.
(b) Values exceeding SOW 787 control limit of $\pm 20 \%$. Indication purpose only.
(c) Results for only one analysis due to the flux and crucible used.


TABLE 2.10. Sum of Acid Digestion and Fusion of Acid Insoluble Residue for SST Sample 102-C

Acid Digestion [A] $(\mathrm{mg} / \mathrm{kg})$

Element Sample 1 Sample 2

$\mathrm{Ag}$

Ai

As

B

$\mathrm{Ba}$

Be

$\mathrm{Ca}$

Cd

Cr

$\mathrm{Cu}$

$\mathrm{Fe}$

K

$\mathrm{Mg}$

$\mathrm{Mn}$

$\mathrm{Na}$

$\mathrm{Ni}$

$P$

$\mathrm{Pb}$

$\mathrm{Sb}$

Se

Si

Sr

$\mathrm{Ti}$

T1

U

$\checkmark$

Zn

Zr 26.1

$$
135,200
$$

39

200

37

$$
1,810^{2.3}
$$

243

$$
253
$$

10,290

330

580

1,950

34,050

2,450

1,190

637

$-160$

160

1,245

40

936

51

21,400

20

220

317

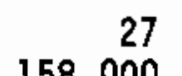

158,000

42

70

40

2.8

2,000

13

248

197

10,950

463

632

2,070

34,500

2,480

1,250

683

$-156$

135

96B

41

1,040

21,300

25

186

356 $\frac{\text { Acid Insol Fused [B] }}{(\mathrm{mg} / \mathrm{kg})}$

Sample 2(b)

Total: $[A]+[B]$ $(\mathrm{mg} / \mathrm{kg})$

Sample 1 Sample 2

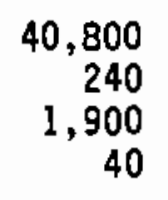

41,800

$175,800 \quad 199,800$

$2,100 \quad 2,100 \quad 3,170$

4,000

47

2,100
77

87

$\begin{array}{rr}2 & 3 \\ 5,800 & 2,000\end{array}$

20

263

248

4,550

253

197

$5,300 \quad 14,800 \quad 16,250$

1,540

107

2,130

330

2,120

2,060

34,950

463
2,760

120

2,190

34,500

590

150

320

220

$-1,780$

360

1,780

2,480

$787 \quad 1,223$

$160 \quad-156$

36,800

26

400

95

20

160

49,300

38,000

50,300

$\begin{array}{rrr}38 & 80 & 125 \\ 450 & 1,340 & 1,490\end{array}$

$450 \quad 1,340 \quad 1,490$

21,500

21,300

20

20

25

240

317

\{05
(a) $\mathrm{KOH} / \mathrm{Ni}$ Fusion
(b) $\mathrm{Na}_{2} \mathrm{O}_{2} / \mathrm{Zr}$ Fusion
(c) Fusion crucible contamination; only one fusion result sumnned. 
TABLE 2.11. Comparison of ICP KOH Fusion Results for SST் Samples 102-C, $105-C$, and $106-C$

\begin{tabular}{|c|c|c|c|}
\hline Element & $\begin{array}{l}\text { Sample } \\
102-c(a) \\
(\mathrm{mg} / \mathrm{kg})\end{array}$ & $\begin{array}{c}\text { Sample } \\
105-\mathrm{C} \\
(\mathrm{mg} / \mathrm{kg})\end{array}$ & $\begin{array}{c}\text { Sample } \\
106-\mathrm{C} \\
(\mathrm{mg} / \mathrm{kg})\end{array}$ \\
\hline \multicolumn{4}{|r|}{2,100} \\
\hline A1 & 225,000 & 246,000 & 115,000 \\
\hline As & 230 & 320 & 390 \\
\hline B & 150 & 300 & 350 \\
\hline $\mathrm{Ba}$ & 110 & 150 & 350 \\
\hline $\mathrm{Ca}$ & 9,400 & 1,600 & 1,900 \\
\hline cd & 80 & 80 & -- \\
\hline $\mathrm{Ce}$ & 60 & 270 & 490 \\
\hline $\mathrm{Cr}$ & 280 & 1,400 & 1,750 \\
\hline $\mathrm{Cu}$ & 280 & 160 & 300 \\
\hline $\mathrm{Fe}$ & 19,500 & 15,300 & 82,400 \\
\hline $\mathrm{Mg}$ & 3,520 & 330 & 420 \\
\hline Mn & 2,300 & 7,120 & 4,500 \\
\hline Mo & 150 & $\therefore$ & $\because$ \\
\hline $\mathrm{Na}$ & 42,600 & 64,400 & 156,000 \\
\hline Nd & 60 & 210 & 560 \\
\hline $\begin{array}{l}P \\
p h\end{array}$ & 3,100 & 5,900 & 7,300 \\
\hline $\begin{array}{l}\text { Pb } \\
\text { Sb }\end{array}$ & 890 & 1,130 & $\begin{array}{r}2,500 \\
,\end{array}$ \\
\hline Se & "- & $\begin{array}{l}2,500 \\
1,000\end{array}$ & $\begin{array}{r}2,900 \\
1,400\end{array}$ \\
\hline Si & 76,800 & 10,800 & 26,000 \\
\hline $\mathrm{Sr}$ & 80 & 160 & 110 \\
\hline$\tilde{T}_{i}$ & 1,750 & 230 & 330 \\
\hline Tו & 2,300 & 1,600 & 1,200 \\
\hline U & 23,300 & 10,500 & $\star \star(b)$ \\
\hline V & & 60 & -- \\
\hline $\mathrm{Zn}$ & 160 & -- & -. \\
\hline $\mathrm{Zr}$ & 1,320 & 710 & 600 \\
\hline
\end{tabular}

(a) Additional Sample 102-C fusion sample analysis performed for comparison with Samples $105-C$ and 106-C. Note values correspond well with those reported in Table 2.9, except for B.

(b) For Sample 106-C the uranium is below the detection limit of the ICP method--uranium by Taser method yielded $8,200 \mathrm{mg} / \mathrm{kg}$ and $944 \mathrm{mg} / \mathrm{kg}$ for Sample 105-C and 106-C, respectively. 
TABLE 2.12. Direct Comparison of the Test Methods by ICP for
SST Sample $102-C$ (in $\mathrm{mg} / \mathrm{kg})(\mathrm{a})$

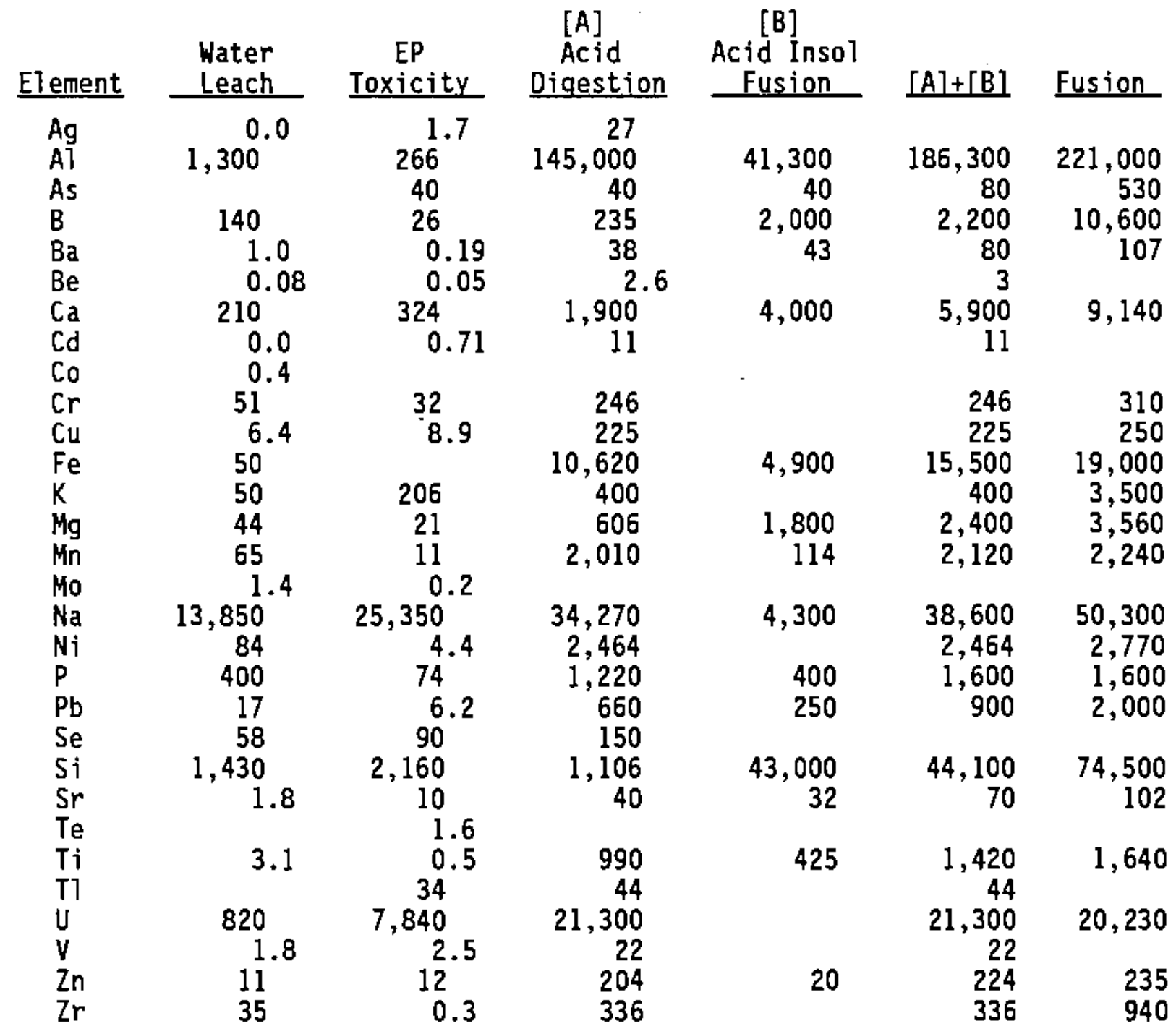

(a) All reported results are averages of duplicate analyses. 
TABLE 2.13. Summary of EP Toxicity Metal Ions by ICP

\begin{tabular}{|c|c|c|c|c|c|}
\hline \multirow{3}{*}{$\frac{\text { Element }}{\mathrm{Ag}}$} & \multicolumn{2}{|c|}{$\begin{array}{l}\text { Sufficient } \\
\text { Sensitivity? }\end{array}$} & \multirow{2}{*}{ Element } & \multicolumn{2}{|c|}{$\begin{array}{c}\text { Sufficient } \\
\text { Sensitivity? }\end{array}$} \\
\hline & With U & Without U & & With U & ithout $U$ \\
\hline & Probable & Probable & $\mathrm{Cr}$ & ProbabTe & Probable \\
\hline As & No & Yes & $\mathrm{Pb}$ & No & Probable \\
\hline $\mathrm{Ba}$ & Yes & Yes & $\mathrm{Se}$ & No & No \\
\hline$c d$ & Yes & Yes & $T 1$ & Ho & No \\
\hline
\end{tabular}

TABLE 2.14. Summary of EPA Pollutant Metal Ions by ICP

$\frac{\text { Element }}{A 1} \frac{B y \text { ICP? }}{\text { Yes }} \cdot \frac{\text { Element }}{\mathrm{Cr}}$ By ICP? $\frac{\text { Element }}{\text { Yes }} \frac{\text { By ICP? }}{\text { Yes }}$

$\begin{array}{llllll}\mathrm{Al} & \text { Yes } & \mathrm{Cr} & \text { Yes } & \mathrm{Na} & \text { Yes } \\ \mathrm{As} & \mathrm{No} & \mathrm{Cu} & \text { Yes } & \mathrm{Ni} & \text { Yes } \\ \mathrm{Ba} & \text { Yes } & \mathrm{Fe} & \text { Yes } & \mathrm{Sb} & \text { Yes } \\ \mathrm{Be} & \text { Yes } & \mathrm{K} & \text { Yes } & \mathrm{Se} & \text { No } \\ \mathrm{Ca} & \text { Yes } & \mathrm{Mn} & \text { Yes } & \mathrm{Tl} & \text { No } \\ \mathrm{Cd} & \text { Yes } & \mathrm{Mg} & \text { Yes } & \mathrm{V} & \text { Yes } \\ \mathrm{Zn} & \text { Yes } & & & & \end{array}$




\subsection{ORGANIC ANALYSIS}

The semivolatile organic analysis was performed on methylene chloride extracts of SST samples. Results of the analysis are described in the following discussion. A description of the experimental work followed by a discussion of the problems and some possible solutions conclude the organic analysis section.

The primary purpose of this project, "to gain additional experience with the analysis of SST matrices," was accomplished with respect to semivolatile organic analysis. Problems associated with the extraction process were encountered and a possible solution evaluated. Problems, most probably associated with the sampling process, were encountered that affected the gas chromatography/mass spectrometry (GC/MS) analysis. Laboratory development work will be required to solve these problems.

\subsection{TEST METHODS, RESULTS, AND SIGNIFICANCE}

\subsubsection{Target Compounds}

Results for three analyses are shown in CLP Form I (IB and IC) in Figures $3.1,3.2$, and 3.3. These results are for the blank and two extracts of the sample (this double extraction is described in Section 3.2.1). The data files and sample descriptions are as follows:

\begin{tabular}{|c|c|c|}
\hline Sample Extract & Dilution & Data File \\
\hline Bl ank & non & LO5 \\
\hline Acidified Sample & to 3 & $>W P L 10$ \\
\hline Unacidified Sample & 1 to 10 & $>W P L 11$ \\
\hline
\end{tabular}

There were no CLP target compounds found in the sample extracts (target compounds are listed in the $1 B$ and $1 C$ forms, "Semivolatile Organics Anatysis Data Sheets"). The "U" signifies that the target compound was undetected at the listed concentration values $(\mu \mathrm{g} / \mathrm{kg}$ or $\mathrm{ppb})$, which are the contract required quantitation $l$ imits (CRQL). The high values for the CRQL reflect the sample dilution. 


\subsubsection{Tentatively Identified Compounds}

There were nontarget compounds found in the two sample extracts. These are shown in the CLP Form $\mathrm{IF}$ in Figures 3.4, 3.5, and 3.6. Note that the estimated concentrations are reported in $\mu \mathrm{g} / \mathrm{g}(\mathrm{ppm})$ rather than the typical $\mu \mathrm{g} / \mathrm{kg}$ (ppb) because of problems in the report generation software. The concentrations are estimated based on a response factors of 1.0 for all of the compounds.

The unacidified sample extract contained mostly alkane and siloxane compounds and the acidified sample extract contained mostly alkanes. Both extracts had what appeared to be oxidized alkanes and perhaps some amines, but their mass spectra did not match well with spectra in the National Institute of Standards and Technology (NIST) mass spectra library. The mass spectra matches became even worse for compounds with long chromatographic retention times.

The presence of high concentration alkanes is probably due to NPH in the core sampling process. The presence of siloxanes is probabiy due to the use of silicone-based lubricants, although gas chromatographic column degradation products have similar mass spectra.

\subsubsection{Surrogate and Matrix Spike Test}

To test for extraction efficiency and matrix effects, all of the sample aliquots were spiked with surrogate compounds and two sets of aliquots were spiked with matrix spike compounds. However, because of the dilutions and the split of the surrogate and matrix spike compounds between the two extracts for each aliquot, the concentrations measured fell below the calibration ranges for those compounds. Consequently, the normal surrogate and matrix spike recovery reports are not included in this report.

\subsubsection{Experimental}

The analyses followed the CLP SOW 288. The extraction process, described in Section 3.2.1, was sonication and was performed in the hot cells. The extract concentration process was carried out in open-faced hoods. 
The concentrated extracts were anaTyzed by GC/MS according to SOW 288 . Before anaiysis, the mass spectrometer was tune checked, and the daily calibration was run to verify the initial calibration. The internal standard checks were within SOW 288 limits for the analyses except for Perylene-d12 in two of the acidified sample extracts. The Perylene-dl2 peak areas for the other acidified sample extracts were also very low.

As mentioned previously, surrogate and matrix spike recoveries were unsatisfactory because of dilutions, so the recovery criteria were not met. This will be further discussed in Section 3.2.2.

\section{1 .5 Screening}

Two screening techniques were tested: the CLP SOW 288 GC method and the TOC method. The results of these techniques are discussed in Section 3.2.1.

\subsection{PROBLEM AREAS AND CORRECTIVE ACTIONS}

\subsubsection{Extraction}

In the first attempt to extract the sample, the low-level sample extraction process was followed with a $5-\mathrm{g}$ sample. The sample was very basic, so a double extraction process was used. The sample was first extracted normally; it was then extracted after acidifying to ensure acid compound extraction (the surrogate and matrix spike compounds were added before the first extraction).

The acidification technique first tested involved adding a small quantity of methylene chloride to slurry the sample and slowly adding $4 \mathrm{M} \mathrm{H}_{2} \mathrm{SO}_{4}$ to a $\mathrm{pH}$ of about 2 as measured with $\mathrm{pH}$ indicator paper. Because of the lead $\mathrm{glass}$ window in the hot cell and probably the effect of methylene chloride on the $\mathrm{pH}$ paper dye, the acidification process was uncertain. When this extract was concentrated to $10 \mathrm{~mL}$, three phases had formed. The solution to this phase-formation problem was to add a calculated amount of $\mathrm{H}_{2} \mathrm{SO}_{4}$ to adjust the sample $\mathrm{pH}$ to 5 (based on the EP Toxicity experiment) and then add additional acid to ensure adequate acidity. By this method, only $1 / 20$ of the acid was added compared to the first method. No problems were encountered in concentrating this extract. In future work, a separate, weighed sample will be 
acidified with a known amount of $\mathrm{H}_{2} \mathrm{SO}_{4}$ to the desired pH so that a good estimate of the amount of acid needed can be made. Also, pH indicator paper will not be used due to the potential of adding organic contamination to the sample.

The value of performing this $\mathrm{pH}$ adjustment before extraction for the very basic samples is seen by the absence of some acidic compounds in the unacidified sample extracts and their presence in the acidified sample extracts. However, the results are inconsistent. That is, some of the acid surrogate and matrix spikes are in the first extract, and the opposite is true for others of the acidic spikes.

In future analyses of very basic samples, the sample pH will be adjusted to 7 to 9 as described previously. The pH-adjusted sample will then be extracted following the normal procedure. In this $\mathrm{pH}$ range, the acidic, basic, and neutral compounds should extract satisfactorily. Although several multivalent metal ions form insoluble precipitates, these precipitates should have little, if any, effect on the extraction of the organic acids.

\subsubsection{Sample Concentration and Composition}

As mentioned, the sample was first extracted following the low-level procedure using a $5 \mathrm{~g}$ sample. The GC/MS analysis was run on both the acidified and unacidified sample extracts with very deleterious effects on the GC column. Not only was the column overloaded, but it was rendered unusable for subsequent runs. No acidic compounds could be measured in calibration standards, and the baseline was noisy and increased significantly at temperatures above $200^{\circ} \mathrm{C}$. Attempts to recover the column were unsuccessful. The extractions were then repeated using the medium-level procedure with $1-g$ aliquots.

By this time, implementation and calibration of the GC screening procedure had been completed, and the low-level, concentrated extraction samples were screened. The results indicated that the unacidified sample extract was about 150 times too concentrated and the acidified sample about 15 times too concentrated based on protocol criteria. Since this screening would normally be done before the final evaporation of the $10 \mathrm{~mL}$ extracts, these extracts appeared to be about 15 and 1.5 times too concentrated for reliable analyses. 
For the medium-level extract with 1-g sample aliquots, rather than the 5-g. low-level extract, the screening indicated that dilutions should be about 3 to 0.5 (i.e., undiluted) for the unacidified and acidified aliquots.

A second screening method tested was the determination of TOC. Results for the TOC were $2.10 \%$ and $2.05 \% \mathrm{C}$ for two aliquots of the sample. From SOW 288 screening protocol, this would indicate that the medium-level extraction procedure should be used and the results agree reasonably well with the GC results if the comparison is estimated on a molar basis.

In order to minimize GC/MS overload and fouling, the medium-level extracts were analyzed at several dilution ratios of the concentrated extracts. The minimum dilutions that could be analyzed without fouling or overload were 1 to 3 for the acidified sample extract and 1 to 10 for the unacidified sample extract. It would appear that these dilutions do not agree with the screening tests. It is likely that constituents in the extracts are causing the problem, rather than column overload.

In future analyses, the GC screening will be performed before the final evaporation step as a guide to the extraction level procedure to be followed. If an extract dilution is necessary, the extraction will be repeated with larger surrogate and matrix spike additions to account for the indicated dilution. The use of both screening methods is recommended until some pattern emerges after a number of analyses, which will hopefully identify the best screening method.

\subsection{TEST PLAN OBJECTIVES}

\subsubsection{To Determine whether the EPA Semivolatile Orqanic Method Can Be Employed on SST Samples}

Results indicate that the SST samples can be analyzed for semi-volatile organic compounds by the CLP SOW 288 procedures, but slight modifications will be required due to the problems associated with use of NPH and siliconebased materials in the SST sampling process. If silicone-based materials are to be used, a method to remove them from the sample extract must be found and implemented. The high concentration of NPH presents a problem in that the extract dilution may dilute organics that are in the SST sample to the point 
that they are difficult to both quantify and identify. Initially, tests will be run to determine if gel permeation chromatography (GPC) can be used for sample cleanup. It is highly recommended that alternatives to GPC be sought and evaluated, since it is unlikely that this method will solve the siloxane and NPH problems. 
1B SEIVOLATIIE ORGNICS NNALYSIS DATA SHEET

EPA SAMPLE NO.

Lab Name: Battelle-PNL

Coneract: - - - - -

89-0073

Lab Code: - Case No.:

-sגs Ho.:

Matr1x: (mo11/uatex) soII

Lab Sample ID: SOLVENT BLA

Sample vt/vol: 1 (g/aL) G

Lab F11] ID: >WPLOS

Lavel: (low/ned) MED

Date Recelved: $04 / 13 / 89$

- Moisture: not dec.-

dec. -

Dace Extracted:04/15/89

Extract1on: (Sep//Cont/Sone) SOHC

Date Analyzed: $4 / 28 / 89$

GPC Cleanup: (Y/H) H

pH:

D1lution Factor: 1.00000

as No.

corrourt

CONCERTRATOK UNITS:

(ug/L ox ug/Kg) ug/Kg

a

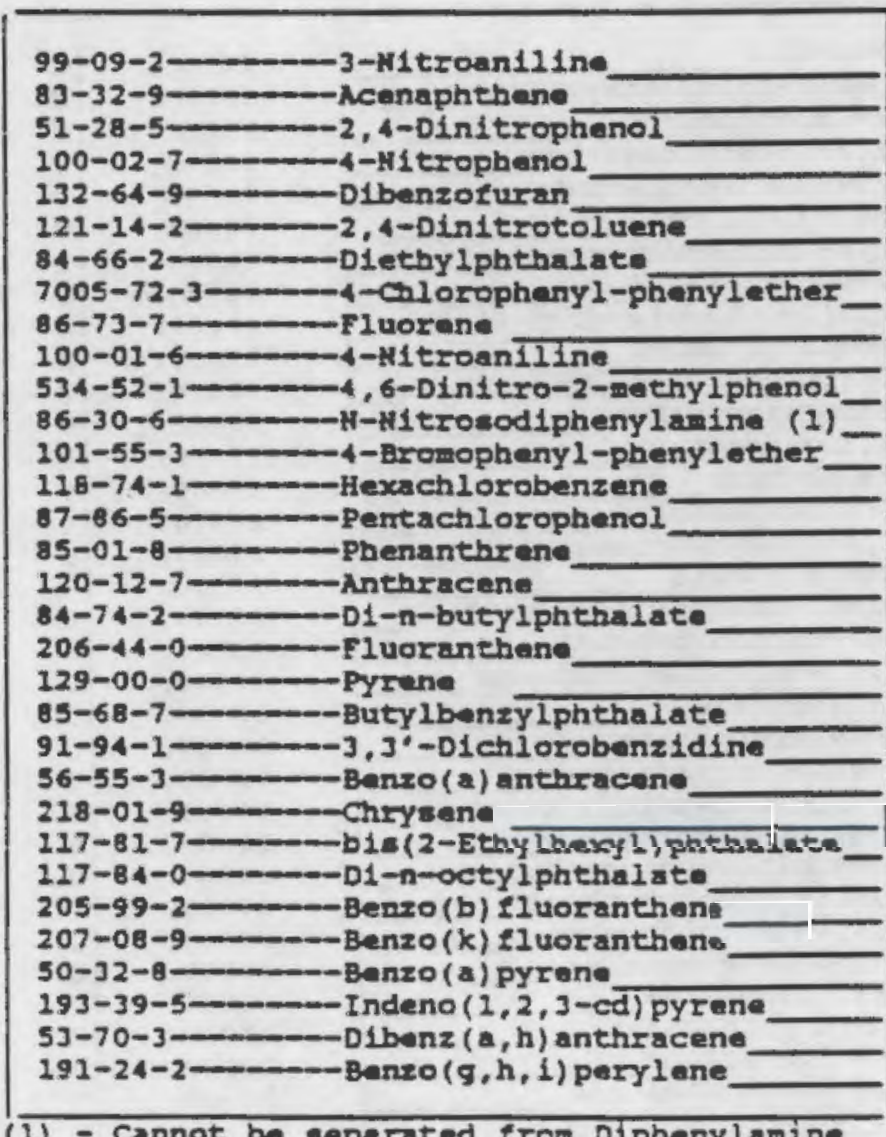

99000.

20000.

99000.

99000.

20000.

20000.

20000.

20000.

20000.

99000 .

99000 .

20000.

20000.

20000.

99000.

20000.

20000.

20000.

20000.

20000.

20000.

40000 .

20000.

20000.

20000.

20000.

20000.

20000.

20000.

20000.

20000.

20000.

(1) - Cannot be eeparated from Diphenylamine

FORH I 5V-2

1/87 Rev.

FIGURE 3.1. Semivolatile Organics Anaiys is Data Sheet 


\section{IC SEMTVOLATILE ORGAMICS NHALYSIS DATA SHEET}

EPA SAMPLE NO.

Lab Name: Bactelle-PNL

Contract:

89-0073

Lab Coda:

Care No.:

-SAS MO.:

Matrix: (soll/water) soIL

Lample ID: SOLVENT ELA

sample we/vol:

2

$(g / m L) G$

Lab F11. ID: >WPLOS

Lavel: (low/and) MED

Date Recelved: $04 / 23 / 89$

\%oleture: not dec.-_ dec. -

Date Extracted: 04/25/89

Extraction: (Sepe/Cont/Sonc) sonC

Date Analyzed: $4 / 28 / 89$

GPC Cleanup: $\quad(\mathrm{Y} / \mathrm{K}) \mathrm{H} \quad \mathrm{PH}:-$

Dilution factor: 1.00000

COHCENTRATION UNITS:

as nо.

COKPOUND

(ug/L or ug/ $\mathrm{Kg}$ ) ug/ $\mathrm{Kg}$

0

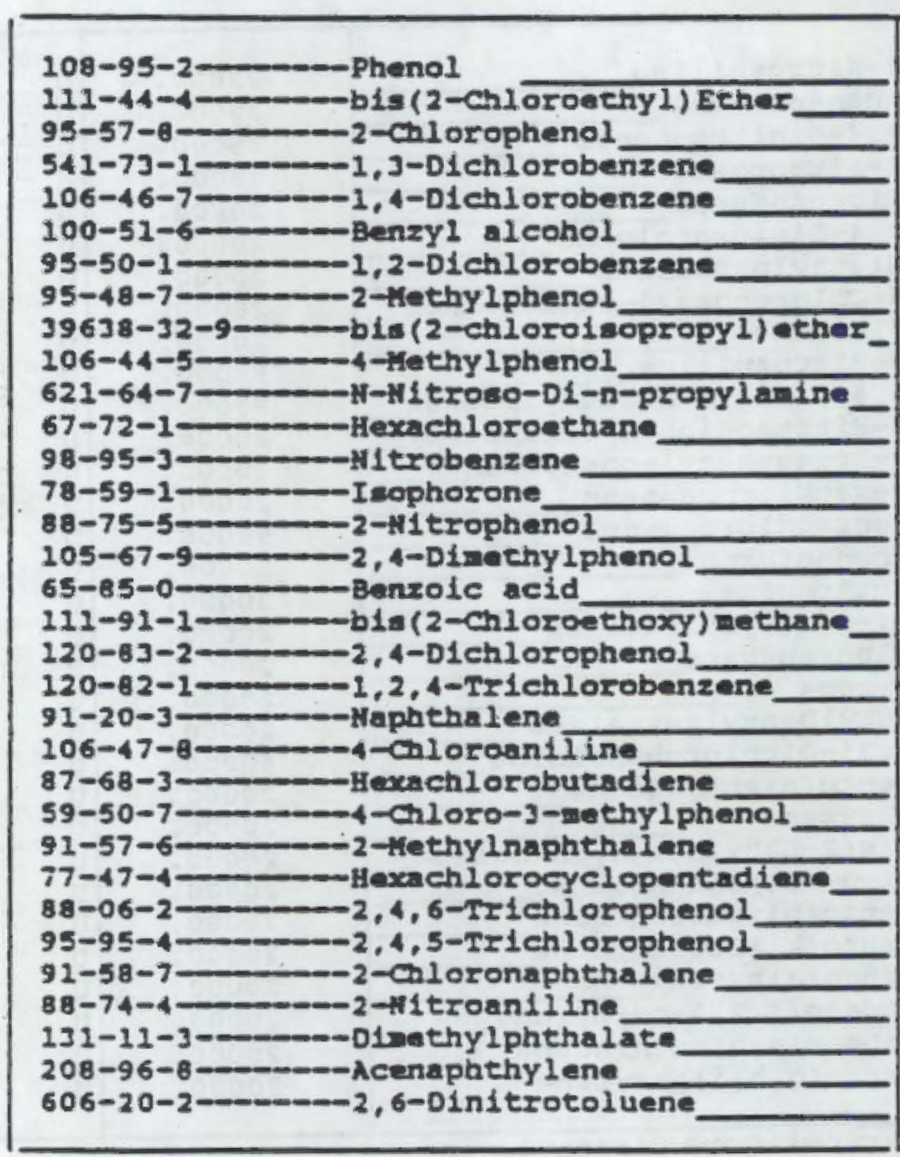

FORM I SV-1

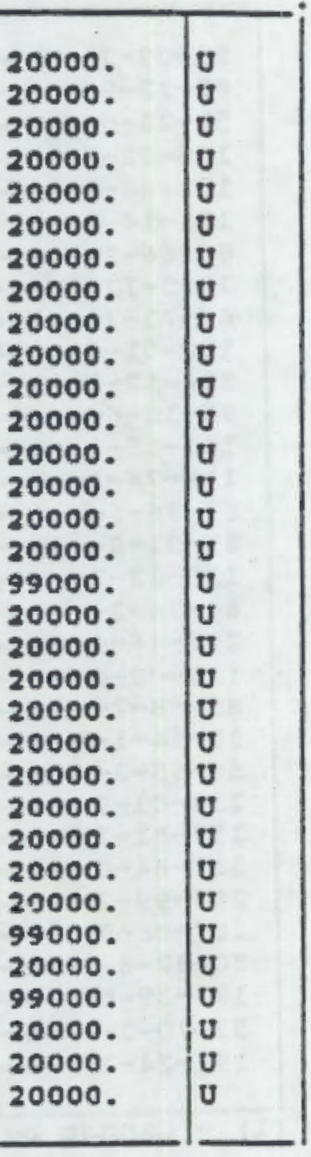

FIGURE 3.1. (contd) 


\section{B SEIVOLATIIZ ORGANICS NHAIYSIS DATA SHEET}

EPA SAMPLE NO.

Lab Name : Battelle-PNL

Contract:- - - - - - -

$89-0012$

Lab Cade: -

-SAS Mo.:

Macrix: (woll/vater) soIL

Sample vt/vol: $\quad 1.0115(g / \mathrm{aL})$ G

Lab Sample ID: TX102C AC E

Level: (low/med) MED

Lab F1le ID: >HPLIO

1 Moleture: not dec..-

dec. - -

Date Recelvad: $02 / 25 / 89$

Extraction: (Sepf/Cone/Sone) SJNC

Date Extracted:03/28/89

GPC Cleanup: $(x / H) \mathrm{H}$

pH:

Dace Analyzed: $4 / 30 / 89$

Dilution Factor: 1.00000

cas to.

COFPOUTD

CONCENTRATION UNIIS:

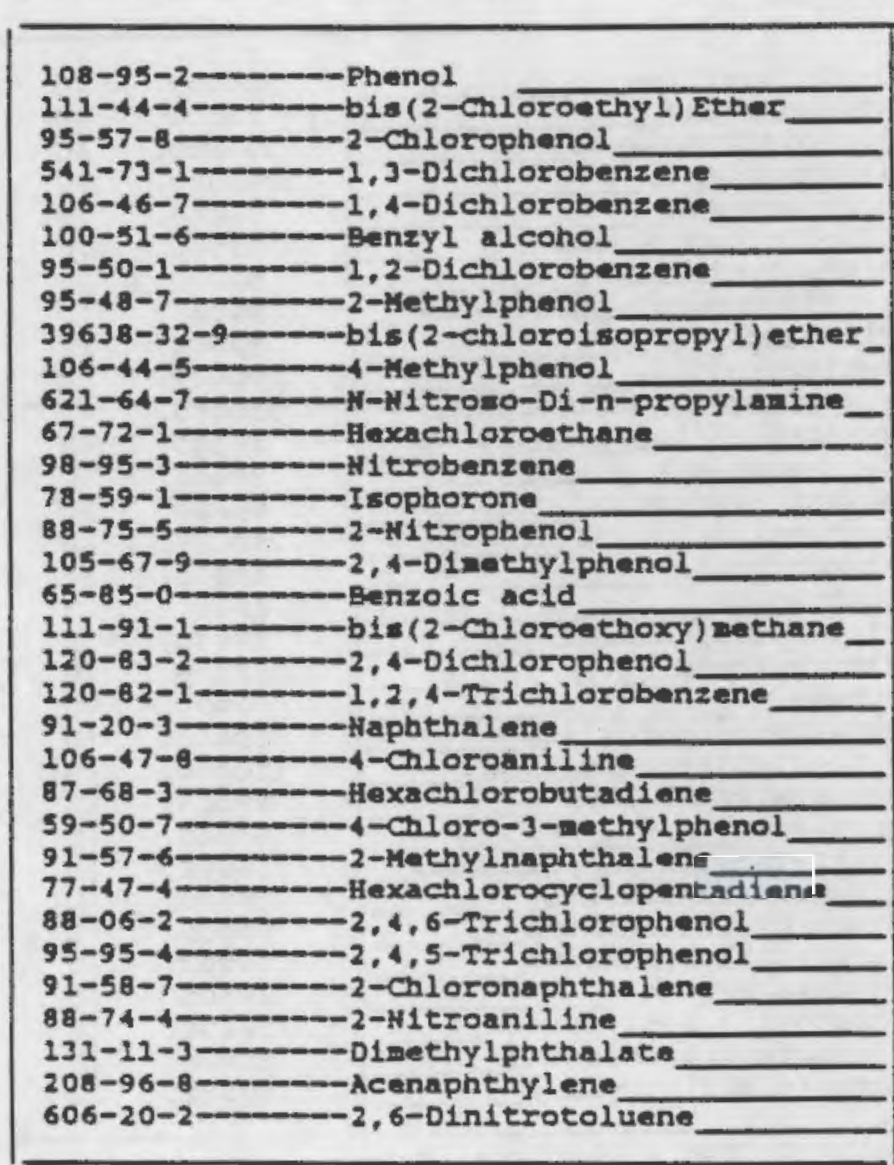

FORA I SV-1
59000.

59000 .

59000 .

59000 .

59000 .

59000 .

59000 .

59000 .

59000 .

59000.

59000.

59000.

59000.

59000.

59000.

59000.

290000.

59000.

59000.

59000.

59000.

59000 .

59000 .

59000.

59000.

59000.

59000.

290000 .

59000 .

290000.

59000 .

59000.

59000 .
8 
Lab Name: Battalle-PNL

Lab code:

Caee Ho.:

SAS No.:
Matrix: (soil/water) SoIL

sample wt,'vol: $1.0215(g / a$ L) $G$

Lavel: (low/zed) MED

1 Moisture: not dec.-

cec. - -

Extraction: (Sept/Cont/Sone) SONC

GPC Cleanup: $\quad(Y / N) N$

pH: -
89-0011 SDG No.: Lab Sample ID: TK202C AC E La F11e ID: >WPLIO Date Racelved: 02/25/89 Date Extracted:03/28/89 Date Analyzed: 1/30/89 Dilution Factor: 1.00000 CONCENTRATION UNITS: cas No. COMPOUND (ug/L or ug/Kg) ug/ Kg

\begin{tabular}{|c|}
\hline 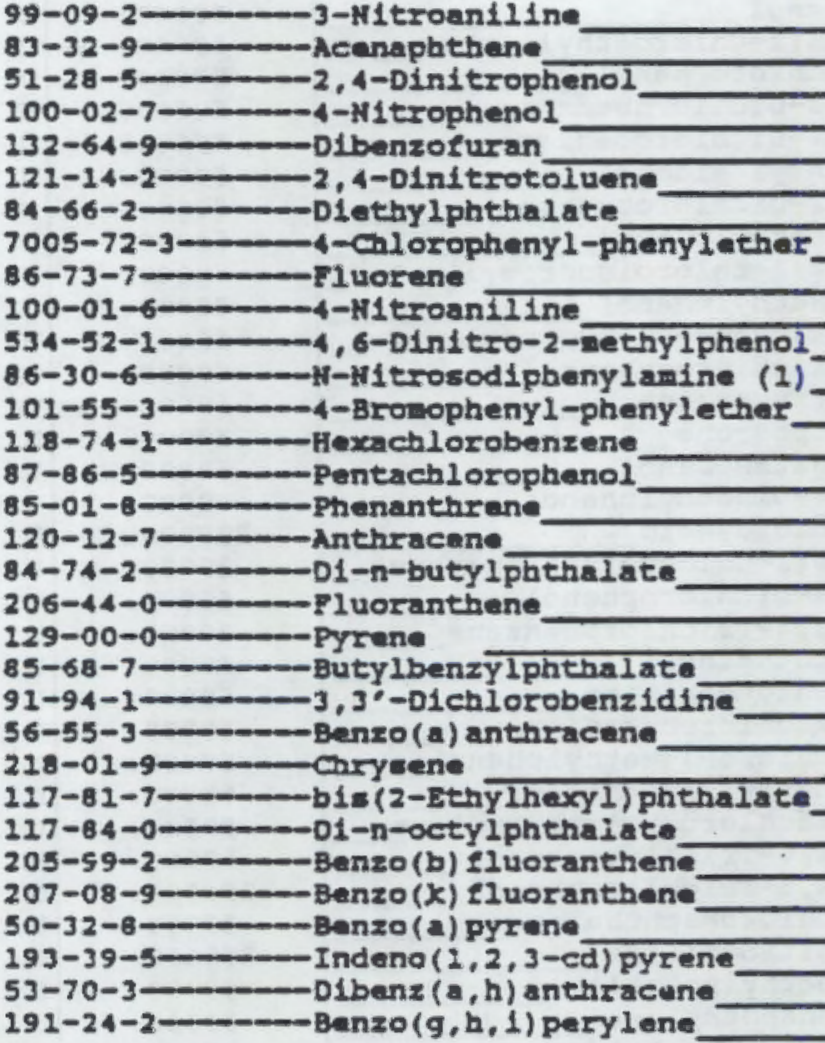 \\
\hline
\end{tabular}

(1) - Cannot be separated frog Diphenylamine

FORM I SV-2

290000.
59000.
290000.
290000.
59000.
59000.
59000.
59000.
59000.
290000.
290000.
59000.
59000.
59000.
290000.
59000.
59000.
59000.
59000.
59000.
59000.
120000.
59000.
59000.
59000.
59000.
59000.
59000.
59000.
59000.
59000.
59000.

1/87 Rev.

\section{FIGURE 3.2. (contd)}


Lab Nama: Battalle-PNL.

Coneract:

69-0011

Lab Code:

Caee No.:

$---\infty-5 A s$ Mo.:

Lab Sample ID: TX202C BN E

Macrix: (so11/vacex) soIL

Lab F11. ID: >WPLII

Sample wt/vol: $\quad 1.0115(g / m L) 6$

Dete Recelved: $01 / 25 / 89$

Lovel: (low/ned) MED

Date Extracted:03/26/89

t Molsture: not dec.- dec. -

Date Analyzed: 4/30/69

Extraction: (Sap//Cont/Sone) SONC

GPC Claanup: $\quad(\mathrm{Y} / \mathrm{N}) \mathrm{Y} \quad \mathrm{PH:}-$

cas No.

CONFouso

D1lution Factor:

1.00000

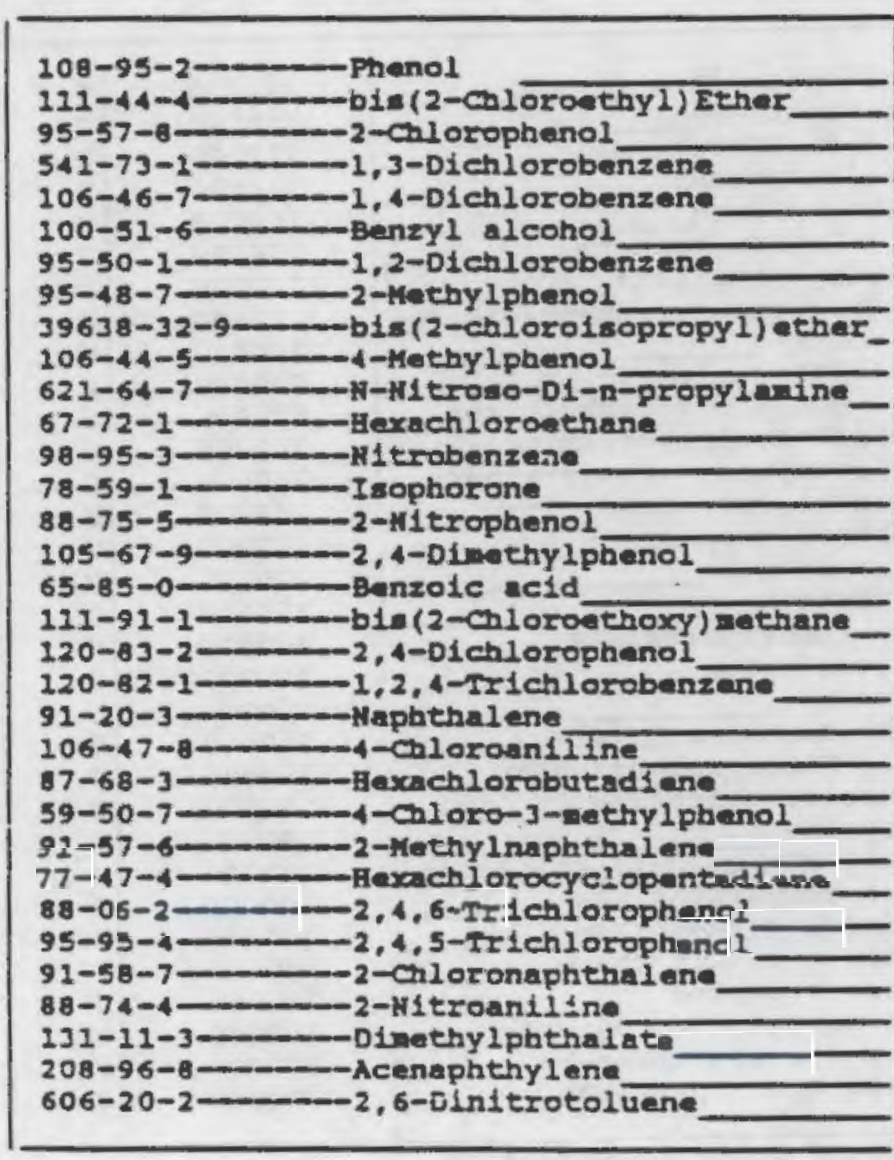

FORM I SV-1
CONCENTRXTION UNITS:

(ug/L or $\mathrm{ug} / \mathrm{Kg}$ ) ug/ $\mathrm{kg}$
0

\begin{tabular}{|c|c|}
\hline 200000. & $\mathbf{U}$ \\
\hline 200000 & $\mathbf{u}$ \\
\hline 200000 & U \\
\hline 200000. & 0 \\
\hline 200000 & 0 \\
\hline 200000. & 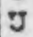 \\
\hline 200000 & $\mathbf{v}$ \\
\hline 200000 & v \\
\hline 200000 & U \\
\hline 200000 & 0 \\
\hline 200000 & $\mathbf{v}$ \\
\hline 200000. & U \\
\hline 200000 & $\mathrm{U}$ \\
\hline 200000 & $\mathbf{U}$ \\
\hline 200000 & $\mathbf{U}$ \\
\hline 200000 & $\mathbf{u}$ \\
\hline 980000. & U \\
\hline 200000 & $\boldsymbol{U}$ \\
\hline 200000 & $\mathbf{U}$ \\
\hline 200000 & $\mathrm{v}$ \\
\hline 200000 & ti \\
\hline 200000. & $U$ \\
\hline 200000. & $\mathbf{v}$ \\
\hline 200000. & $\mathbf{v}$ \\
\hline 200000 & 0 \\
\hline 200000 & $\mathbf{v}$ \\
\hline 200000. & $\mathbf{0}$ \\
\hline 980000. & $\mathrm{U}$ \\
\hline 200000. & $\mathbf{U}$ \\
\hline 980000. & $\mathbf{u}$ \\
\hline 200000 & $\mathrm{U}$ \\
\hline 200000. & $U$ \\
\hline 200000 & $\mathbf{v}$ \\
\hline
\end{tabular}

$1 / 87$ Rev.

FIGURE 3.3. Semivolatile Organics Analys is Data Sheet 


\section{C SEIIVOLATIII ORGANICS NNALYSIS DATA SHEET}

EPA SAMPLE NO.

Lab Nawe: Batte11e-PHL Contract:--_-

89-0011

Lab code:

Case Ho.:

SAS Mo.:

Lab Sample ID: TX102C BN E

Matrix: (wo11/water) soIL

Sample wt/vol: $\quad 2.0115(g / \mathrm{aL})$ G

Lab F11. ID: >WPLII

Lovel: (10w/med) MED

Date Received: 01/25/89

Hoilfeure: not dec.-- dec. -

Date Extracted: $03 / 28 / 89$

Extraction: (Sepr/Cont/sone) SONC

Date Analyzan: 4/30/89

GPC Cleanup: (Y/H) $\mathrm{H}$ PH:-

Dilueion Factor: 1.00000

cas no.

COMPOUND

COHCENLRATON UNITS:

(ug/I or ug/ $\mathrm{Kg}$ ) ug/ $\mathrm{kg}$

Q

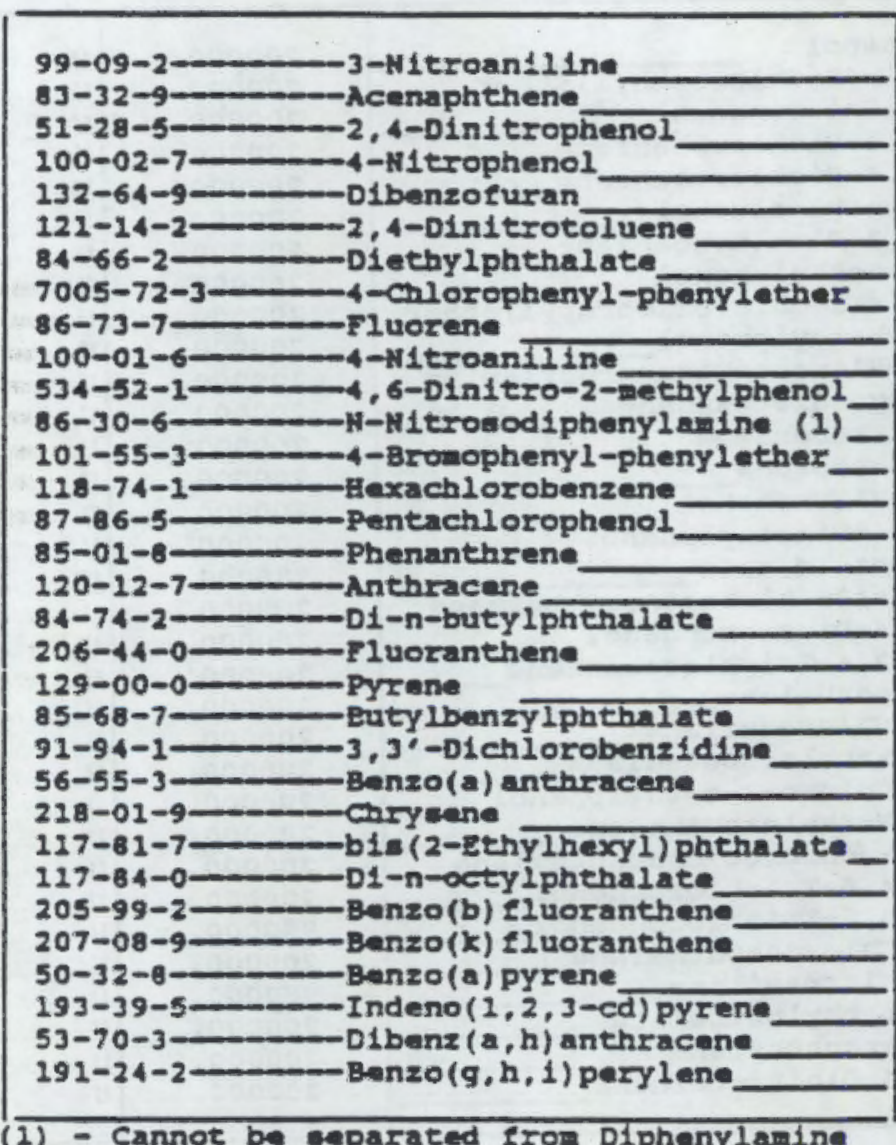

980000 . 200000 . 980000 .

980000 . 200000 . 200000 . 200000 . 200000 . 200000 . 980000 . 980000 . 200000. 200000 . 200000 . 980000 . 200000 . 200000. 200000 . 200000. 200000. 200000. 390000 . 200000. 200000 . 200000 . 200000 . 200000 . 200000 . 200000 . 200000 . 200000 . 200000 .

FORH I SV-2

1/87 Rev.

FIGURE 3.3 . (contd) 
IF EEMTVOLATILI ORGNICS NALLYIS DATA SHEET TENTATIVELY IDENTIFIED COMPOUNDS

Lab Name: Bactelle-PNL

Contract:-_-

EPA SAMPLE NO.

Lab Coda:

Case No.:

SAS Mo.:

89-0073

Matrix: (eofl/vacer) sorl

Lab Sample ID: SOLVENT BUA

Sample ve/vol:

1

$(g / m L) G$

Lab F11e ID: >WPLOS

Level: (Low/ned) MED

Date Recelved: $04 / 13 / 89$

+ Moleture: not dec.-_ dec. -

Date Extracted:04/15/89

Extraction: (Sopt/Cont/Sonc) SONC

Date Analyzed: $4 / 28 / 89$

GPC Cleanup: (Y/K) N PH:-

D1lution Factor: 1.00000

CONCENIRATION UNIIS: ug/gm

Number IICs found: 3

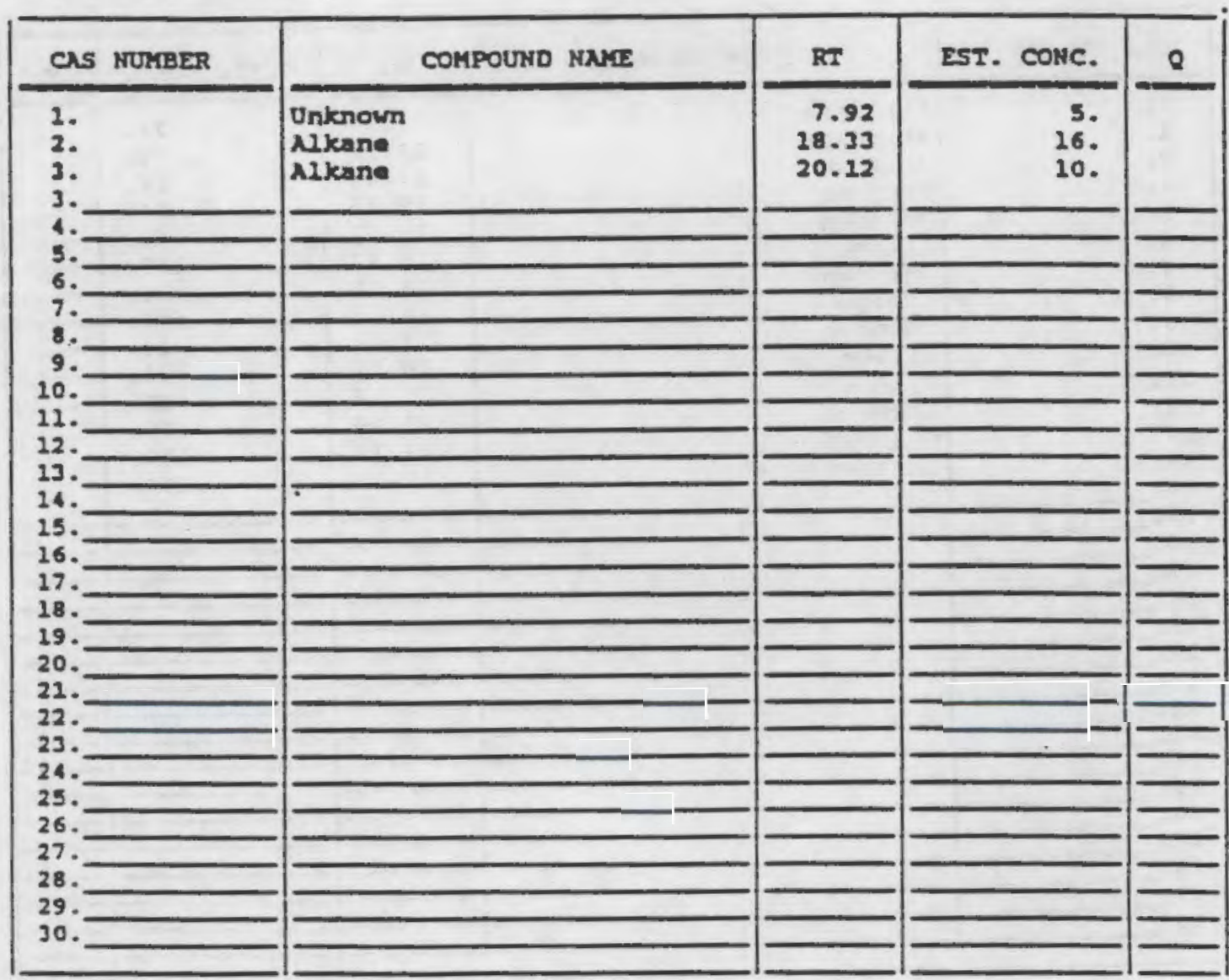

FIGURE 3.4. Semivolatile Organics Analys is Data Sheet Tentatively Identified Compounds 
IF SEIVOLATILE ORGANICS NNALYSIS DATA SHEET TENTATIVELY IDENTIFIED COMPOUNDS

Lab Name: Battelle-PNL

Contrace:
EPA SAMPLE NO.

89-0011

Lab Code:

Caee No.:

sns No.:

SDG HO.:

Matr1x: (soil/vater) soIL

Sample wt/vol: $\quad 1.0115(g / \mathrm{mL})$ G

Lab Sampie ID: TKI02C AC E

Lovel: (Low/med) MED

Lab F1le ID: >WPLIO

Date Received: 01/25/99

Holeture: not dec.-n dec. -

Date Extracted:03/28/89

Extraction: (Sepl/Cont/Sonc) SONC

Date Analyzed: 4/30/89

GPC Cleanup:

(Y/M) $\mathrm{H}$

pH :

D1lution Factor: 1.00000

Number IICs round: 14

CONCENTRATION UAITS: ug/gm

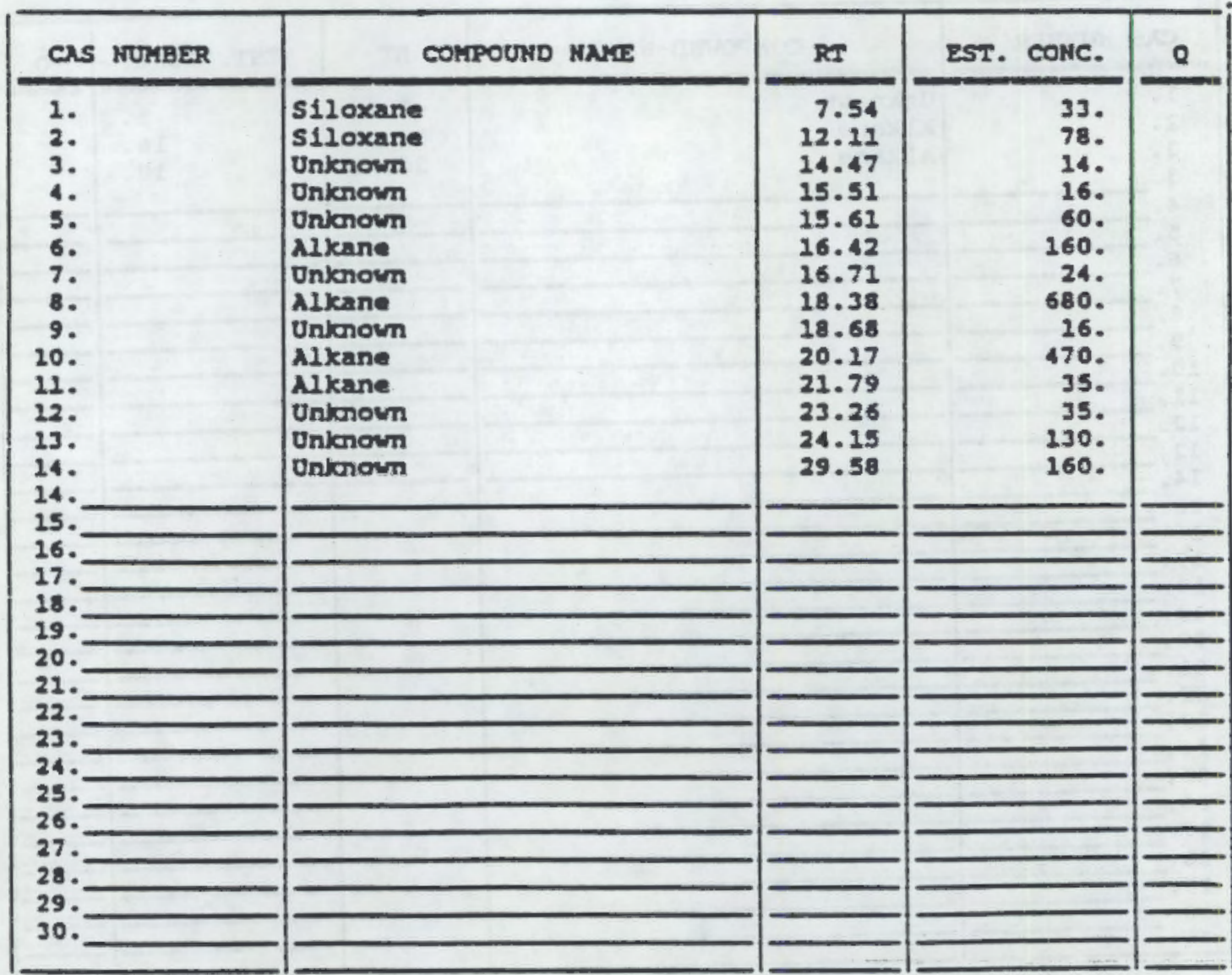

FIGURE 3.5. Semivolatile Organics Analysis Data Sheet Tentatively Identified Compounds 
1F SEIIVOLATIIE ORGNICS NALYSIS DATA SHEET TENTATIVELY IDENTIFIED COMPOUNDS

Lab Name: Batealle-PNL

Contract: $-20-0-0-1-$

EPA SNMPL: NO.

Lab Coda:

Case No.:

-sNs No.:

99-0011

Matrix: (so1l/water) SoIL

Lat Sample ID: TK102C BN E

Sample rt/vol:

$1.0115(g / \mathrm{mL}) 6$

Lab F11e ID: >WPLI1

Lovel: (low/nod) MED

Date Recelved: $01 / 25 / 89$

+ Moleture: not dec.

dec. -

Date Extrected:03/28/89

Extraction: (Sepe/Cont/Sone) SONC

Date Analyzed: $4 / 30 / 89$

GPC Cleanup:

(Y/M)

pH: $-\infty-\infty$

Dilution Factor:

1.00000

Number IICs found:

21

CONCINTRATION UNIIS: ug/gm

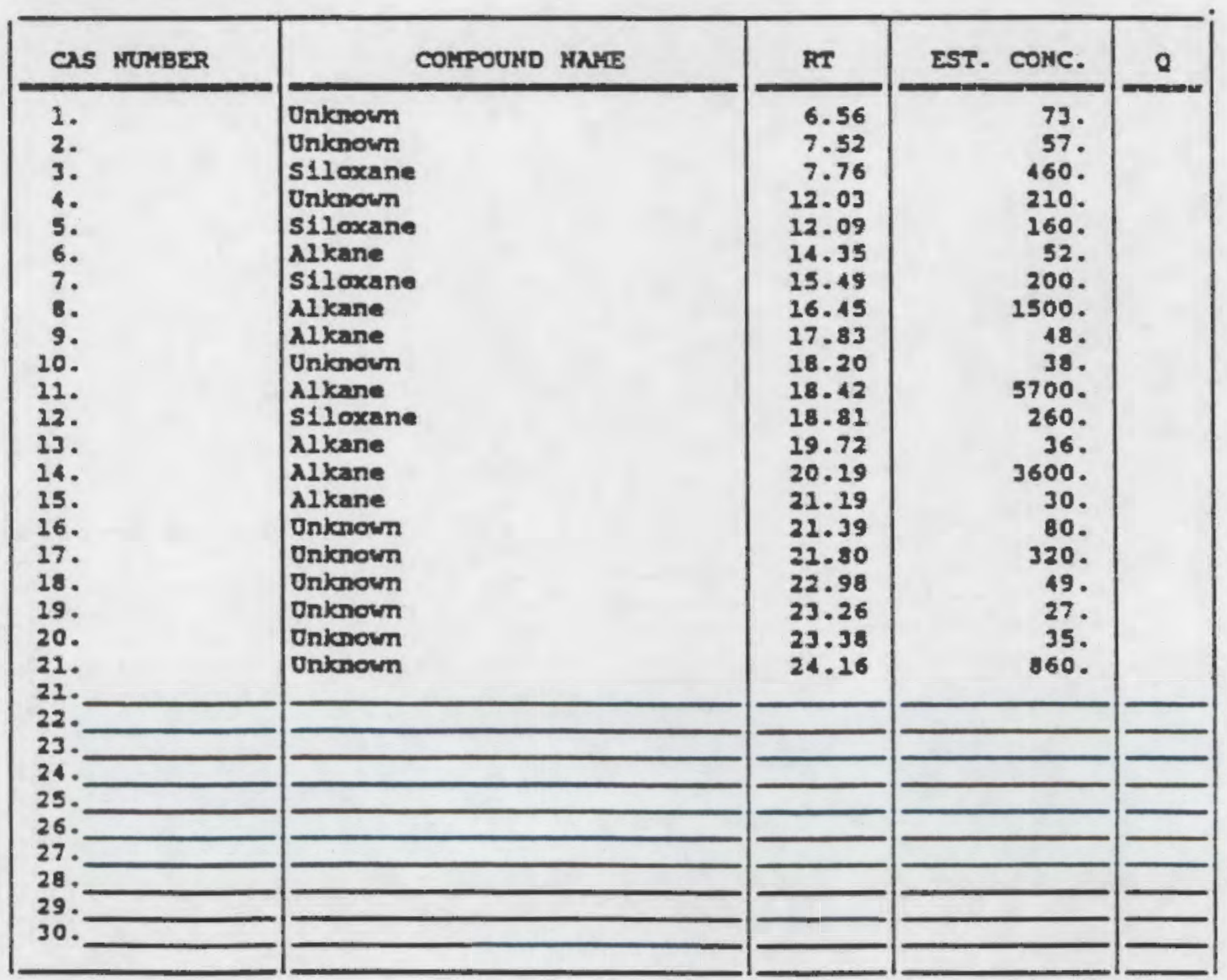

FIGURE 3.6. Semivolatile Organics Analysis Data Sheet Tentatively Identified Compounds 

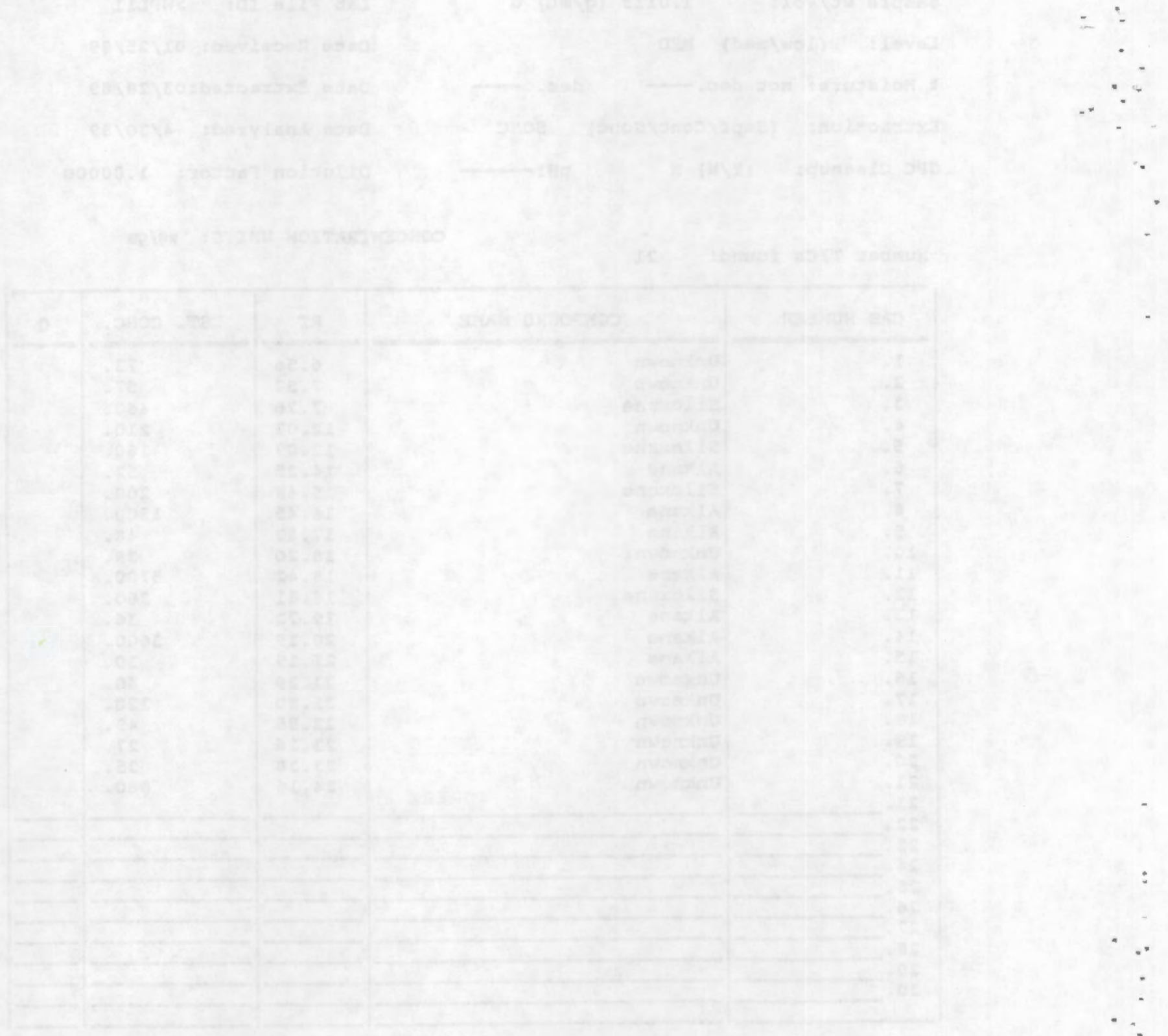


\subsection{RADIONUCLIDE ANALYSIS}

Radionuclide analyses were performed on fused and dissolved samples from SST $105-C$ and 106-C. In addition to the radiochemical measurements requested in Table 1 of the Test Plan (see Appendix), WHC also asked that total aipha, total beta, and gamma energy anaiysis (GEA) be performed on both samples. The primary objectives of the radionuclide measurements were to determine if the analytical methods were adequate for analysis of SST samples and to identify those cases for which modifications or additional procedure development are needed. Satisfactory measurements were obtained for radioisotopes of An, $\mathrm{Cm}, \mathrm{Ni}, \mathrm{Pb}, \mathrm{Po}, \mathrm{Pu}, \mathrm{Ra}, \mathrm{Se}$, and $\mathrm{U}$. Further procedure development will be needed for radioisotopes of $\mathrm{Ac}, \mathrm{Cs}, \mathrm{Nb}, \mathrm{Pa}, \mathrm{Sm}$, Th, and $\mathrm{Zr}$.

\section{I TEST METHODS, RESULTS, AND SIGNIFICANCE}

\subsubsection{Sample Fusion}

Weighed portions of SST archive samples $105-C$ and $106-C$ were fused by two different methods: 1) in $\mathrm{KOH}$ using a $\mathrm{Ni}$ crucible $(\mathrm{KOH} / \mathrm{Ni})$, as described in Figure 8 of the Test Plan (see Appendix), and 2) in $\mathrm{Na}_{2} \mathrm{O}_{2}$ using a $\mathrm{Zr}$ crucible $\left(\mathrm{Na}_{2} \mathrm{O}_{2} / \mathrm{Zr}\right)$. Total a]pha, total beta, and GEA measurements were made on acidified aliquots of dissolved samples from both fusion methods. Only the solutions resulting from the $\mathrm{KOH} / \mathrm{Ni}$ fusions were used for further radiochemistry.

\subsubsection{Summary of Radiochemical Measurements}

The results of total alpha, total beta, and GEA anaiyses on SST samples 105- $C$ and 106-C are given in TabTe 4.1. Satisfactory agreement between duplicate analyses, using the $\mathrm{KOH} / \mathrm{Ni}$ and $\mathrm{Na}_{2} \mathrm{O}_{2} / \mathrm{Zr}$ fusion methods, was obtained for the total alpha and total beta results for sample 105-C. For sample 105-C, the total alpha and total beta results from the $\mathrm{Na}_{2} \mathrm{O}_{2} / \mathrm{Zr}$ fusion were somewhat higher than from the KOH/Ni fusion. The ${ }^{137} \mathrm{Cs}$ results by GEA agreed wel1 for the two fusion methods, and this isotope was by far the predominant gamma activity for both samples.

The radiochemistry results for all analyses except the $U$ isotopic analyses are presented in Table 4.2. The radioactivity is reported in units 
of $\mathrm{nCi} / \mathrm{g}$ except for the case of total $U$, which is given in units of $\mathrm{mg} / \mathrm{kg}$ for comparison with ICP fusion results. Table 4.2 also gives percent yield values for the duplicate analyses for those cases where a radioactive tracer was added. Some of the radiochemical measurements were not completed because of difficulties with the procedures, as will be discussed later.

The $U$ isotopic measurements were performed by isotope dilution mass spectrometry and are presented in Table 4.3. Each of the SST samples was analyzed directily and also analyzed spiked with $20 \mathrm{ng}$ of ${ }^{233} \mathrm{U}$.

\subsection{PROBLEM AREAS AND CORRECTIVE ACTIONS}

Sample 105-C was fused by both the $\mathrm{KOH} / \mathrm{Ni}$ and $\mathrm{Na}_{2} \mathrm{O}_{2} / \mathrm{Zr}$ methods. When the total alpha and GEA results were initially compared, the values were considerabiy different. Since no visible precipitate or undissolved particles were observed after acidification, the difference could not be attributed to incomplete dissolution of the sample. The problem was determined to be due to either a contaminated crucibie or volumetric flask. Therefore, the 105-C sample fusions were repeated using new crucibles and new glassware, and then the reproducibility of the total alpha and GEA values were within acceptable Timits, as reported in Table 4.1. This finding demonstrates that all new equipment is required for the analysis of each sample.

Although Ni metal crucibles are inexpensive and easily obtained, they cannot be used when ${ }^{59} \mathrm{Ni}$ and ${ }^{63} \mathrm{Ni}$ measurements are required, since $\mathrm{Ni}$ dissolves into the fusion melt and absorbs the low-energy radiation emitted by these isotopes. Zr metal crucibles avoid this problem, but they are expensive, difficult to obtain in quantity, and $\mathrm{Zr}$ interferes with the radiochemical measurement of ${ }^{93} \mathrm{Zr}$ in a similar manner. If $\mathrm{Zr}$ crucibles are re-used, cross-contamination of samples could be a serious problem due to the large variation in activity levels anticipated for different samples.

Although good agreement between fusion methods was obtained for ${ }^{137} \mathrm{Cs}$ by GEA, this was not true for other ganma activities in either sample.... A method that would allow selective separation of Cs from the fusion melt solution is 
needed. This might reduce by orders of magnitude the ${ }^{137} \mathrm{Cs}$ gamma activity and thereby improve the detection 7 imit for other gamma emitters in SST samples.

The two SST archive samples that have been analyzed to date may or may not be truly representative of SST waste tank sludge, and the chemical composition may even vary considerably within a given tank. Considerable adaptation of the various radiochemical procedures may be necessary in order to perform the desired measurements.

The current status of the procedures for each of the radionuclides in Table 1 of the Test PTan (see Appendix) will now be discussed.

\subsubsection{Radionuclides ${ }^{227} \mathrm{AC}$}

Rather than measure the ${ }^{227} \mathrm{AC}$ directly, the 18.7-day daughter ${ }^{227}$ Th was measured. This is a valid method for determining ${ }^{227} \mathrm{AC}$ in SST samples since the parent and daughter will be in secular equilibrium. The two samples were run in duplicate, with ${ }^{228} \mathrm{Th}$ added as a tracer for chemical yield estimation. Adequate separation from other alpha-enitters was achieved to allow calculation of upper limits to the ${ }^{227} \mathrm{AC}$ activity for both $105-\mathrm{C}$ and $106-\mathrm{C}$ samples. However, for one of the duplicates, Pu was not separated well enough to allow detection of ${ }^{227} \mathrm{Th}$. Therefore, further refinements to the separation procedure will need to be developed before this method can be considered reliable.

4.2.2 Radionuclides ${ }^{241} \mathrm{Am}, 242 \mathrm{Am},{ }^{263} \mathrm{Am}$, and ${ }^{242} \mathrm{Cm}$

Due to their similar chemistry, Am and $\mathrm{Cm}$ were separated and purified together and measured by alpha energy analysis (AEA). Results for ${ }^{242}$ Am are not reported, since this isotope cannot be easily measured by counting methods. Since measurement of ${ }^{243}$ Am was requested, and this isotope is also used as the isotopic tracer in the PNL. method, the procedure was performed twice, once with and once without the addition of ${ }^{243} \mathrm{Am}$. If measurement of ${ }^{262} A m$ is also required, a mass spectrometric analysis procedure witl need to be used. 


\subsubsection{Radionuclides ${ }^{135} \mathrm{Cs}$ and ${ }^{137} \mathrm{Cs}$}

Measurement of ${ }^{135} \mathrm{Cs}$ was unsuccessful because, with the procedure that was used, insufficient $C s$ was recovered for mass spectrometric analysis. The method involved selective retention of the $C_{s}$ on cation exchange resin, and $i t$ is likely that the high $K$ content of the solution resulting from the $\mathrm{KOH} / \mathrm{Ni}$ fusion prevented the $\mathrm{Cs}$ from being retained. A procedure was developed that appeared to remove $X$ successfully from a synthetic SST sampie. This involved precipitation of $K$ by addition of sodium tetraphenylborate, and was successful on the synthetic sample, but was not attempted on either of the archive samples. The effect of adding additional $\mathrm{Na}$ during the ion exchange separation of $C s$ was not studied. As an aiternative, it may be more straightforward to use the existing procedure, but to separate the ${ }^{135} \mathrm{Cs}$ from an aliquot following acid digestion of the SST sample, since the $K$ content would be much lower. Further procedure development is needed.

\subsubsection{Radionuclides ${ }^{59} \mathrm{Ni}$ and ${ }^{63} \mathrm{Ni}$}

Analyses for these $\mathrm{Ni}$ radioisotopes are not possible if fusion is performed in a $\mathrm{Ni}$ metal crucible, as discussed earlier. An al ternate method for measurement of ${ }^{59} \mathrm{Ni}$ may be ICP/MS. This might be simpler if the detection limit proved to be adequate, but the method would have poor sensitivity for ${ }^{63} \mathrm{Ni}$ due to its much shorter half-1ife. At this time PNL does not have the capability for measuring radioactive samples by ICP/MS, but this capability should be in place during the first half of FY 1990.

\subsubsection{Radionuclides ${ }^{94} \mathrm{Nb},{ }^{231} \mathrm{~Pa}$, and ${ }^{93} \mathrm{Zr}$}

No procedure currently exists for the analyses of these nuclides in SST matrices. Some procedure development work was performed based on ion exchange methods with sequential elution of $\mathrm{Zr}$, $\mathrm{Nb}$, and $\mathrm{Pa}$. Tracer studies look promising, but no measurements were attempted on SST sampies. Additional procedure development will be necessary. 


\subsubsection{Radionuclides ${ }^{210} \mathrm{~Pb},{ }^{226} \mathrm{Ra}$, and ${ }^{228} \mathrm{Ra}$}

Upper limit values of $0.5 \mathrm{nCi} / \mathrm{g}$ for ${ }^{210^{\circ}} \mathrm{Pb}$ and $5 \mathrm{nCi} / \mathrm{g}$ for ${ }^{226} \mathrm{Ra}$ are reported. However, significant interferences were observed from gamnaemitting species when the samples were counted. Since some of the anticipated SST samples are expected to contain high Tevels of ganuna emitters, it will be necessary to modify these procedures in order to obtain better separation. Due to these interference probiems, ${ }^{228} \mathrm{Ra}$ measurements could not be performed.

An alternative for the measurement of ${ }^{210} \mathrm{~Pb}$ would be to measure the ingrowth of the daughter, ${ }^{210} \mathrm{Po}$. This would improve the sensitivity if a delay of approximately 100 days would be acceptable.

\subsubsection{Radionuclide ${ }^{210} \mathrm{P}_{0}$}

Less-than values of $0.002 \mathrm{nCi} / \mathrm{g}$ were calculated for $210 \mathrm{Po}$.

4.2.8 Radionuclides ${ }^{238} \mathrm{Pu},{ }^{230} \mathrm{Pu},{ }^{240} \mathrm{Pu}$, and ${ }^{242} \mathrm{Pu}$.

Results reported in Table 4.2 for ${ }^{238} \mathrm{Pu}$ and for ${ }^{239+240} \mathrm{Pu}$ were determined by AEA. The PNL procedure that was used requires ${ }^{242} \mathrm{Pu}$ as an isotopic tracer, so it was performed with and without the addition of the tracer. Less-than values were calculated for ${ }^{242} \mathrm{Pu}$ from the latter data. A mass spectrometric procedure is also available at PNL for the measurement of $\mathrm{Pu}$ isotopes. This method is more expensive, but is capable of greater accuracy and allows measurement of other $\mathrm{Pu}$ isotopes, such as ${ }^{261} \mathrm{Pu}$.

\subsubsection{Radionuclide ${ }^{79} \mathrm{Se}$}

Results for ${ }^{79}$ Se are reported in Table 4.2. However, the existing PNL procedure is lengthy and has not given reliably good carrier recovery for the anatysis of fused SST samples. Modifications are currently being made to this method that give improved radiochemical yield, and these modifications need to be tested on fused SST samples. Additional procedure development may be necessary.

This radionuclide is a good candidate for analys is by ICP/MS when the capability becomes available. 


\subsubsection{Radionuclide ${ }^{151} \mathrm{Sm}$}

This radionuclide is difficult to measure by radiochemical means because of its low-energy (21.4 keV) ganma emission. Adequate separation of any radionuclides that emit higher-energy gamma radiation is essential due to Compton background interference. Europium radioisotopes are of particular concern because they are difficult to separate from Sm.

A procedure was evaluated using ${ }^{151} \mathrm{Sin}$ radioactive tracer, and $85 \%$ recovery of the Sm was obtained. A tracer study was then conducted using ${ }^{154} \mathrm{Eu}$ and various carriers to determine the degree of separation of Eu from $\mathrm{Sm}$. The best separation achieved to date is $75 \%$ removal of Eu from the Sm fraction. Further procedure development will be necessary in order to verify that adequate separation from Eu is attainable.

4.2.11 Radionuclides ${ }^{229} \mathrm{Th},{ }^{230} \mathrm{Th}$, and ${ }^{232} \mathrm{Th}$

The chemistry adapted for SST sample analysis of Th isotopes was originally developed for the analysis of groundwater, where the only interfering species are due to naturally occurring radioactivity. In SST samples, fission products, including rare earth beta and gamma emitters, Pu, Am, and other actinides wi1l be present. The adaptations that were investigated to cope with these interferences were not adequate to allow detection of Th a]pha emission.

A revised radiochemistry scheme is recommended based on removal of Pu by solvent extraction after reduction to the +3 oxidation state. Several such soivent extraction systems exist. An optimum system should be chosen after consideration of the radionuclides expected to be present in SST samples. Additional methods development will be necessary for measurement of Th isotopes.

4.2.12 Radionuclides ${ }^{233} \mathrm{U}, 234 \mathrm{U}, 235 \mathrm{U},{ }^{236} \mathrm{U}$, and ${ }^{238} \mathrm{U}$

An isotope dilution, mass spectrometric procedure was used, with addition of a ${ }^{233} \mathrm{U}$ spike. Since analysis for ${ }^{233} \mathrm{U}$ was requested, the procedure was also repeated without addition of the spike. At one stage of the 
procedure, unleached glassware was used, so there is the possibility of some sample contamination with natural $U$ leached from the glass.

\subsubsection{Total U}

No problems were encountered in the laser fluorometric method for total $U$ analysis. For SST sample $105-C$, the $U$ result by ICP was $10,500 \mathrm{mg} / \mathrm{kg}$ versus a result of $8,200 \mathrm{mg} / \mathrm{kg}$ by the laser method. No ICP result was obtained for SST sample 106-C.

\subsection{TEST PLAN OBJECTIVES}

\subsubsection{To Determine if There Are Problems with Employing the Various Analytical Methods on the Test Samples}

Additional procedure development will be required for the measurement of ${ }^{94} \mathrm{Nb},{ }^{231} \mathrm{~Pa},{ }^{227} \mathrm{Ac},{ }^{79} \mathrm{Se},{ }^{93} \mathrm{Zr},{ }^{229} \mathrm{Th},{ }^{230} \mathrm{Th},{ }^{232} \mathrm{Th},{ }^{242} \mathrm{Am},{ }^{151} \mathrm{Sm},{ }^{210} \mathrm{~Pb}$, ${ }^{226} \mathrm{Ra}$, and ${ }^{228} \mathrm{Ra}$. Modifications to the existing procedure will be necessary for ${ }^{135} \mathrm{Cs}$. Approved procedures are not in place for determination of most of the radionuclides listed in Table 1 of the Test Plan (see Appendix) for SST matrices.

TABLE 4.1. Total AIpha, Total Beta, and GEA Results for SST Samptes 105-C and 106-C

\begin{tabular}{|c|c|c|c|c|}
\hline \multirow[b]{2}{*}{ Radionuclide } & \multicolumn{2}{|c|}{ Sample $105-\mathrm{C}(\mathrm{nCi} / \mathrm{q})$} & \multicolumn{2}{|c|}{ Sample $106-\mathrm{C}(\mathrm{nCi} / \mathrm{g})$} \\
\hline & $\mathrm{KOH} / \mathrm{Ni}$ & $\mathrm{Na}_{2} \mathrm{O}_{2} / \mathrm{Zr}$ & $\mathrm{KOH} / \mathrm{Ni}$ & $\mathrm{Na}_{2} \mathrm{O}_{2} / \mathrm{Zr}$ \\
\hline Total $\alpha$ & $\begin{array}{l}1.17 \mathrm{E} 3 \\
1.15 \mathrm{E} 3\end{array}$ & $\begin{array}{l}1.40 E 3 \\
1.30 E 3\end{array}$ & $4.13 \mathrm{E} 3$ & $3.99 \mathrm{E} 3$ \\
\hline $\begin{array}{l}\text { Total } \beta \text { as } \\
90 \mathrm{Sr} / 90 \mathrm{Y}\end{array}$ & $\begin{array}{l}3.63 \mathrm{E} 6 \\
3.89 \mathrm{E} 6\end{array}$ & $\begin{array}{l}3.89 E 6 \\
4.03 E 6\end{array}$ & $\begin{array}{l}8.83 \mathrm{EE} \\
8.56 \mathrm{E6}\end{array}$ & $\begin{array}{l}8.56 \mathrm{E} 6 \\
8.15 \mathrm{E} 6 \\
8.34 \mathrm{E} 6\end{array}$ \\
\hline GEA $\begin{array}{r}137 \mathrm{Cs} \\
{ }^{60} \mathrm{Co} \\
154 \mathrm{Eu} \\
125 \mathrm{Sb}\end{array}$ & $\begin{array}{l}3.02 \mathrm{ES} \\
3.73 \mathrm{E2} \\
2.68 \mathrm{E3}\end{array}$ & $\begin{array}{l}3.05 \mathrm{E} 5 \\
6.17 \mathrm{E2} \\
3.82 \mathrm{E} 3\end{array}$ & $\begin{array}{l}4.82 \mathrm{E} 5 \\
1.16 \mathrm{E} 3 \\
5.40 \mathrm{E} 3\end{array}$ & $\begin{array}{l}5.04 \mathrm{E} 5 \\
7.88 \mathrm{E} 2 \\
7.97 \mathrm{E} 3 \\
5.68 \mathrm{E} 3\end{array}$ \\
\hline
\end{tabular}


TABLE 4.2. Radiochemical Measurements and Tracer Yields for SST Samples 105-C and 106-C

\begin{tabular}{|c|c|c|c|c|}
\hline Radionuclide & $\begin{array}{l}\text { Activity } \\
\text { (nCi/g) }\end{array}$ & $\begin{array}{l}\text { YieTd } \\
(\%) \\
\end{array}$ & $\begin{array}{r}\text { Activity } \\
(\text { nCi/g) } \\
\end{array}$ & $\begin{array}{l}\text { Yield } \\
(\%)\end{array}$ \\
\hline $227 \mathrm{AC}$ & $<1.4$ & $1-2$ & $<0.9$ & $1-2$ \\
\hline $241 \mathrm{Am}$ & $962 \pm 38$ & 22,27 & $2824 \pm 98$ & 42,26 \\
\hline $243 A_{m}$ & $4.9 \pm 1.3$ & $n$ & $19.2 \pm 2.1$ & $n$ \\
\hline $242 \mathrm{~cm}$ & $3.0 \pm 0.3$ & $n$ & $10.5 \pm 0.7$ & $n$ \\
\hline $244 \mathrm{Cm}$ & $29.5 \pm 1.4$ & $n$ & $129 \pm 5$ & $"$ \\
\hline${ }^{238} \mathrm{Pu}$ & $48 \pm 5$ & 62,72 & $422 \pm 11$ & 51,44 \\
\hline $239 \mathrm{Pu}$ & $747 \pm 126$ & $"$ & $2340 \pm 57$ & $n$ \\
\hline $242 \mathrm{Pu}$ & $<0.2$ & $n$ & $<0.4$ & $"$ \\
\hline \multicolumn{5}{|l|}{${ }^{135} \mathrm{Cs}$} \\
\hline${ }^{59} \mathrm{Ni}$ & $128 \pm 5$ & 61,76 & $68 \pm 14$ & 87,88 \\
\hline${ }^{63} \mathrm{Ni}$ & $12885 \pm 1804$ & $"$ & $7770 \pm 1508$ & $n$ \\
\hline \multicolumn{5}{|l|}{$94 \mathrm{Nb}$} \\
\hline \multicolumn{5}{|l|}{$231 \mathrm{~Pa}$} \\
\hline $210 \mathrm{pb}$ & $<0.2$ & & $<0.3$ & \\
\hline $210 \mathrm{Po}$ & $<.002$ & & $<.002$ & \\
\hline $226 \mathrm{Ra}$ & $<5 ?$ & & $<5 ?$ & \\
\hline \multicolumn{5}{|l|}{$228 \mathrm{Ra}$} \\
\hline${ }^{79} \mathrm{Se}$ & $2.5,2.5^{(a)}$ & & $0.95,0.53(a)$ & \\
\hline $151 \mathrm{Sm}$ & & & & \\
\hline
\end{tabular}

Th Isotopes

Total U (mg/kg)

8200

98.8

944

101.3

(a) Replicate analysis. 
TABLE 4.3. Uranium Isotopic Analyses on SST Samples 105-C and 106-C

Sample 105-C

$U$ With ${ }^{233} U(a)$ Without ${ }^{233} U$

Mass

233

234

235

236

238
Atom \%

0.02264

0.00510

0.65665

0.01247

99.30313 Atom $\%$

0.00719

0.00913

0.65070

0.02243

99.31055

(a) Addition of $20 \mathrm{ng}$ of $233 \mathrm{U}$.

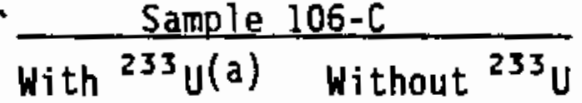

Atom \% Atom \%

$0.19040 \quad 0.00067$

0.00615

0.00558

0.64334

0.65239

0.01942

0.01157

99.14069

99.32980 


\subsection{NORMAL PARAFFIN HYDROCARBON STUDIES}

Normal paraffin hydrocarbon is used as part of the core sampling process. Therefore, it is important to know whether inorganic anions and cations and radionuclides are soluble in this medium. To evaluate solubility, a slurry consisting of SST sample 106-C and SST sample 102-AX supernate was contacted with NPH for a period of $48 \mathrm{~h}$. An al iquot of NPH was removed for radiochemical analysis. The remaining NPH was then back-extracted with water and I $M$ nitric acid and the inorganic species determined by ICP.

\subsection{TEST METHODS, RESULTS, AND SIGNIFICANCE}

\subsection{Experimental}

A slurry consisting of $14.4 \mathrm{~g}$ of solid sample from SST $106-\mathrm{C}$ and $26.8 \mathrm{~g}$ of SST sample 102-AX supernate was prepared and contacted with NPH in accordance with Figure 10 of the Test Plan (see Appendix). After centrifuging, a $10 \mathrm{~mL}$ al iquot of the NPH phase was removed from the hot cell for GEA analysis. The remaining NPH was then contacted with an equal volume of water, and an aliquot of the aqueous phase was analyzed for inorganic species. The NPH was then contacted with an equal volume of $1 \mathrm{M}$ nitric acid, and the inorganic species were measured in the acid phase. NPH blank solutions were generated by contacting virgin NPH with water and with $1 \mathrm{M}$ nitric acid.

\subsubsection{ICP Inorganic Constituent Solubility Results}

The primary inorganic constituents found in the $\mathrm{NPH}$ were $\mathrm{P}, \mathrm{Na}$, and $\mathrm{NO}_{3}$, as shown in Table 5.1. The NPH blanks were run to determine what was extractable from the NPH itself. Upon evaluation of the data, it is obvious that the $P$ is not all in the form of phosphate ions. It is suspected that it is present as an organo-phosphorus compound that was extracted from the SST sample. The high $\mathrm{Na}$ and $\mathrm{NO}_{3}$ content in the extracts correlates with the high $\mathrm{Na}$ and $\mathrm{NO}_{3} / \mathrm{NO}_{2}$ content of the SST sample. 


\subsubsection{Radionuclide Solubility Results}

Results of the radiochemical measurements on the NPH in units of $\mathrm{nCi} / \mathrm{mL}$ are given in Table 5.2. No alpha, beta, or GEA anaTyses of the combined 106-C and 102-AX supernate slurry were performed; therefore, no direct quantitative determination of the extraction of radionuclides into NPH could be calculated. However, these counting measurements were performed for SST sample 106-C and are presented in Table 4.1. By comparison of Tables 4.1 and 5.2 , the level of extraction of radionuclides into NPH is considered to be insignificant. The percent of total alpha and total beta activity extracted was $0.004 \%$ and $0.0012 \%$, respectively. From the GEA data, the percent of ${ }^{137} \mathrm{Cs}$, ${ }^{60} \mathrm{Co}$, and ${ }^{154} \mathrm{Eu}$ activity extracted was $0.026 \%, 0.076 \%$, and $0.003 \%$, respectively.

\subsection{IEST PLAN OBJECTIVES}

\subsubsection{To Determine the Solubility of Inorganic and Radiochemical Ions in NPH}

As discussed previously, most of the measured ions showed no significant difference between the NPH/SST and the NPH/blank samples. The higher $B$ and $\mathrm{Si}$ in the NPH/SST sample is probably due to radiation damage to the borositicate glass vessel used for extraction. The high $\mathrm{Na}$ and $\mathrm{K}$ are probably physical carryover from the synthetic sludge. The source of the $P$ is most likely from a degradation product of tri-butylphosphate (TBP). Even though the ICP, IC, and radiochemical results for this archive composite indicate low solubility of the measured ions in NPH, it may be prudent to confirm these results on future core samples. 
IABLE 5.1. ICP and IC Measurements for NPH Equilibrated with Composite of SST Samples $106-C$ and 102-AX

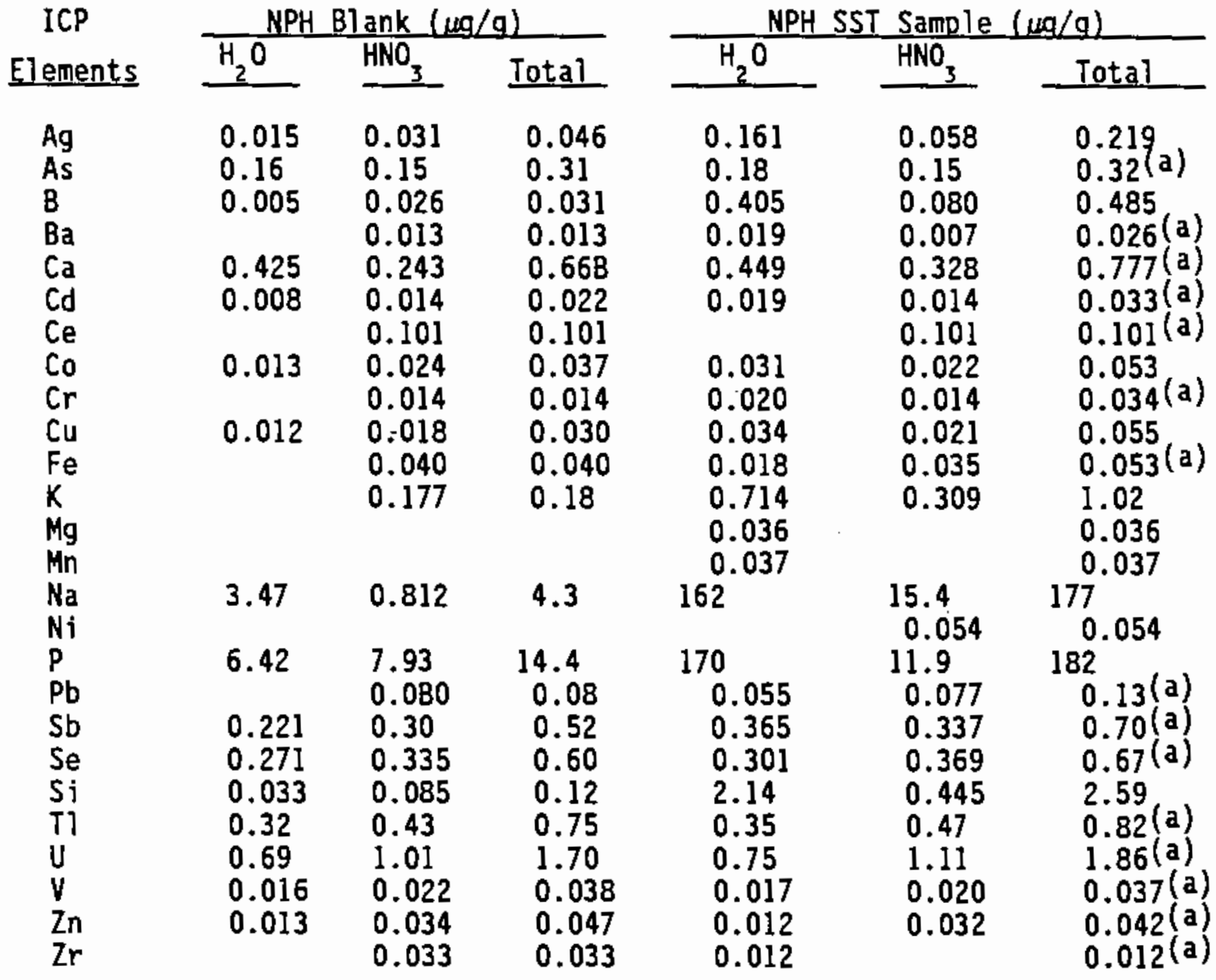

IC

Anions
$\mathbf{F}$
$<0.08$
C1 $\quad 0.12$
$\mathrm{NO}_{2}<0.08$
$<0.08(a)$
8.1
$\begin{array}{ll}\mathrm{NO}_{3} & 2.8 \\ \mathrm{PO}_{4} & <0.4\end{array}$
$\mathrm{SO}_{4} \quad 0.43$
37.9
$4.2(a)$

(a) Elements which show no significant difference between the sample and the blank. 
TABLE 5.2. Total Alpha, Total Beta, and GEA Results on NPH Equilibrated with Composite of SST Samples 106-C and 102-AX

$\begin{array}{cc}\begin{array}{c}\text { Gamma } \\ \text { Energy Analysis }\end{array} & \frac{(n \mathrm{Cj} / \mathrm{mL})}{127.0} \\ { }^{137} \mathrm{Cs} & 0.88 \\ { }^{60} \mathrm{Co} & 0.17 \\ { }^{154} \mathrm{Eu} & \\ \text { Total Alpha } & \frac{\text { Total Beta }}{\left({ }^{90} \mathrm{Sr}-90 \mathrm{Y}\right)} \\ 0.18 & 106.0\end{array}$




\subsection{RADIOLOGICAL EXPOSURE STUDY}

Estimates of radiological exposure were made based on radiation measurement at contact and at a distance of about $3 \mathrm{ft}$ for the sample aliquots removed from the hot cell for the inorganic, organic, and radiochemical analyses. Estimates were also made of the amount of time that the analyst would be in the contact with the sample when performing each of the various procedures. Thus, it is possible to obtain information on the radiation exposure that would be received in performing the various analyses.

\subsection{IEST METHODS, RESULTS, AND SIGNIFICANCE}

\subsubsection{Experimental}

The analyst recorded the volume of sample used in each procedure, and estimated the time in contact with the sample. These data were entered into radiation exposure study forms for each procedure. Exposure was held to a minimum by use of ALARA (As Low As Reasonable Achievable) sample handling methods.

\section{1 .2 Exposure Summary}

The SST samples $102-C$ and $105-C$ were much lower in activity than SST sample 106-C. No significant exposure to personnel was received in performing any of the measurements. The data from the radiation exposure study forms were used to sumarize the radiation exposure received by the analyst and are presented in Tables 6.1 and 6.2 . 
IABLE 6.1. Exposure Data Summary for Radiochemical Separations

Sample Procedure Used

\begin{tabular}{|c|c|c|c|c|}
\hline $\begin{array}{l}\text { Volume Removed } \\
\text { from Hot Cell } \\
\text { (mL) }\end{array}$ & $\begin{array}{l}\text { Exposure } \\
\text { Contact } \\
\text { (mR/hr) }\end{array}$ & $\begin{array}{l}\text { Leve] } \\
3 \text { feet } \\
(\mathrm{mR} / \mathrm{hr})\end{array}$ & $\begin{array}{l}\text { Volume Used } \\
\text { for Analysis } \\
\text { (mL) }\end{array}$ & $\begin{array}{l}\text { Time in Contact } \\
\text { with Sample (est.) } \\
\text { (min) }\end{array}$ \\
\hline
\end{tabular}

\begin{tabular}{|c|c|c|c|c|c|}
\hline $\begin{array}{l}\text { Sample } \\
\frac{105-C}{\text { Ni fusion, }} \\
\text { Radiochemical } \\
\text { separation } \\
\text { for Ac }\end{array}$ & 5 & 5 & $<1$ & 2 & 20 \\
\hline $\begin{array}{l}\text { Sample } \\
\frac{106-C}{\text { Ni fusion, }} \\
\text { Radiochemical } \\
\text { separation } \\
\text { for AC }\end{array}$ & 5 & 25 & 2.5 & 1 & 10 \\
\hline $\begin{array}{l}\text { Sample } \\
\frac{105-C}{\text { Zr fusion, }} \\
\text { Radiochemical } \\
\text { separations } \\
\text { for } \mathrm{Pu}, \mathrm{Am}, \\
\mathrm{Ni}, \mathrm{Po}, \mathrm{Pb}, \mathrm{Ra}\end{array}$ & 5 & 7 & $<1$ & 4.2 & 65 \\
\hline $\begin{array}{l}\text { Sample } \\
106-\mathrm{C} \\
\text { Zr fusion, } \\
\text { Radiochemical } \\
\text { separations } \\
\text { for } \mathrm{Pu}, \mathrm{Am}, \\
\mathrm{Ni}, \mathrm{Po}, \mathrm{Pb}, \mathrm{Ra}\end{array}$ & 5 & 30 & 3 & 4.2 & 65 \\
\hline $\begin{array}{l}\text { Sample } \\
\frac{105-C}{\text { Zr fusion, }} \\
\text { Radiochemical } \\
\text { separations } \\
\text { for Po, Pb, } \\
U \text {, Th }\end{array}$ & 50 & 7 & $<1$ & 20 & 60 \\
\hline $\begin{array}{l}\text { Sample } \\
106-C \\
\text { Zr fusion, } \\
\text { Radiochemical } \\
\text { separations } \\
\text { for Po, Pb, U, }\end{array}$ & 50 & 30 & 3 & 20 & 60 \\
\hline
\end{tabular}


TABLE 6.2. Exposure Data Summary for Inorganic Analyses

Sample Procèdure Used

Volume Removed

from Hot Cell

$(\mathrm{mL})$
Exposure Leve] Contact $(\mathrm{mR} / \mathrm{hr}-\mathrm{bkgd})(\mathrm{mR} / \mathrm{hr})$

$40-3$ Volume Used Time in Contact for Analysis with Sample (est.) $(\mathrm{mL})$

(min)

\begin{tabular}{|c|c|c|c|c|c|}
\hline $\begin{array}{l}\text { Sample } \\
\frac{102-C}{\text { EP Toxicity, }} \\
\text { Sample \#1, } \\
\text { ICP al iquot }\end{array}$ & 100 & $40-3$ & $<0.5$ & 100 & 5 \\
\hline $\begin{array}{l}\text { Sample } \\
102-C \\
\text { EP Toxicity, } \\
\text { Sample \#2, } \\
\text { ICP aliquot }\end{array}$ & 100 & 35-2.5 & $<0.5$ & 100 & 5 \\
\hline $\begin{array}{l}\text { Sample } \\
\frac{102-C}{\text { KOH Fusion }}\end{array}$ & 10 & $4.5-<0.5$ & $<0.5$ & 10 & 5 \\
\hline $\begin{array}{l}\text { Sample } \\
\frac{102-\mathrm{C}}{\mathrm{Na}_{2} \mathrm{O}_{2}} \text { Fusion }\end{array}$ & 10 & $4.0-<0.5$ & $<0.5$ & 10 & 5 \\
\hline $\begin{array}{l}\text { Sample } \\
102-C \\
\text { Fused Solids } \\
\text { from Acid } \\
\text { oigestion, } \\
\text { Sample \#1 }\end{array}$ & 10 & $1.0-<0.5$ & $<0.5$ & 10 & 5 \\
\hline $\begin{array}{l}\text { Sample } \\
102-C \\
\text { Fused Solids } \\
\text { from Acid } \\
\text { Digestion, } \\
\text { Sample } \# 2\end{array}$ & 10 & $<0.5-<0.5$ & $<0.5$ & 10 & 5 \\
\hline
\end{tabular}




\section{APPENDIX}

TEST PLAN FOR ANALYSIS OF ARCHIVE SAMPLES OF SINGLE-SHELL TANK SAMPLES PROVIDED BY WESTINGHOUSE HANFORD COMPANY 
REVISION 0

Approval Oate 2-1-39

\section{SINGLE-SHELL TANK TECHNOLOGY SUPPORT PROGRAM}

TEST PLAN FOR ANALYSIS OF ARCHIVE SANPLES OF

SINGLE-SHELL TANK SAMPLES PROVIDED BY WESTINGHOUSE HANFORD COMPANY

PRO.JECT 13924

HB5 8930
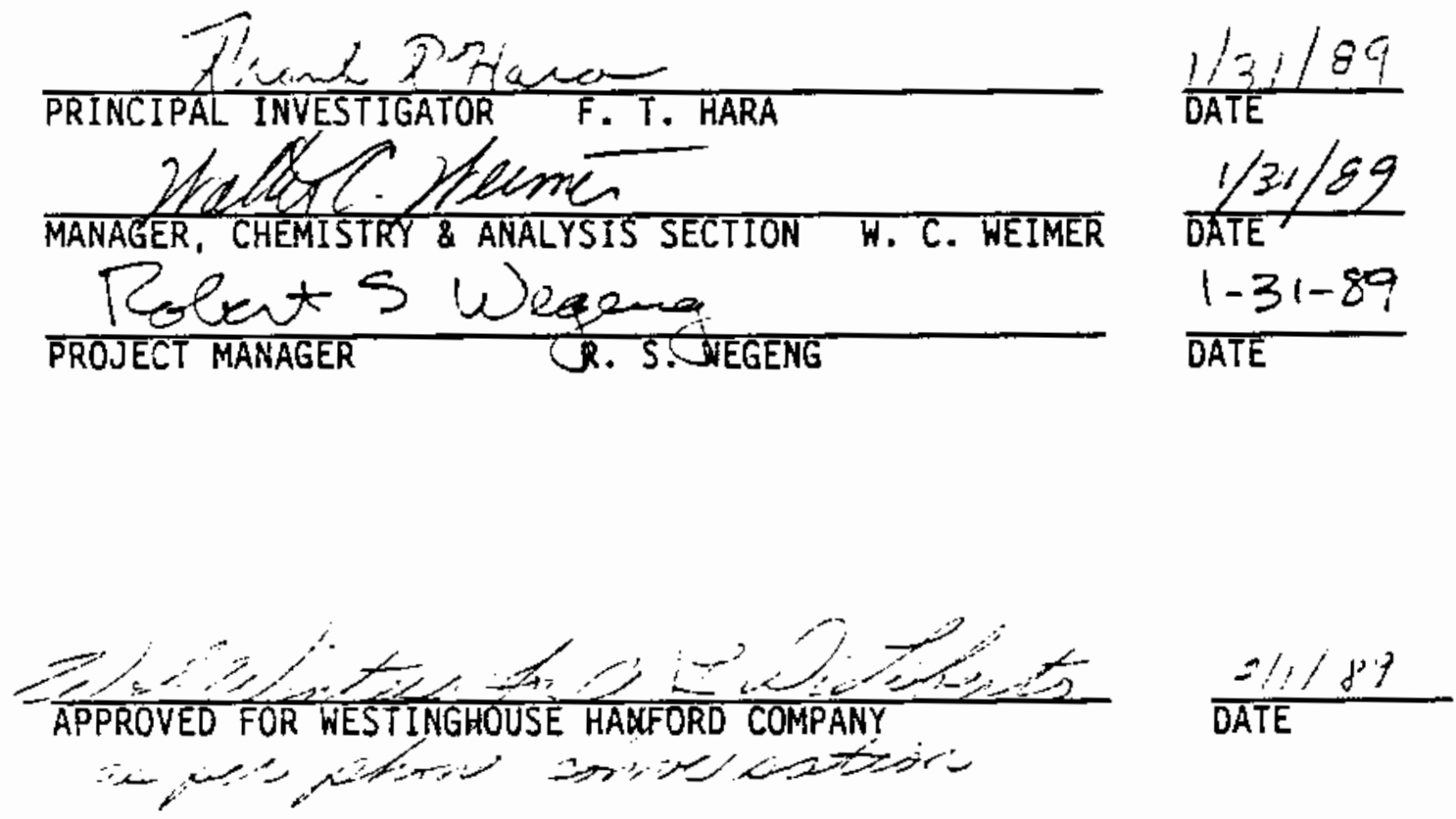
REVISION 0

Approval Date 2-1-89

Page

I. INTRODUCTION 1

II. SCOPE AND OBJECTIVES 1

III. TEST METHODS 2

$\begin{array}{ll}\text { Sample Preparation } & 2 \\ \text { Percent Solids } & 2 \\ \text { Water Leach } & 2 \\ \text { EP Tox } & 2 \\ \text { Acid Digestion } & 8 \\ \text { Mercury Analysis } & 8 \\ \text { Total Cyanide } & 8 \\ \text { Fusion Procedure/Radionuclides } & 3 \\ \text { Semivolatile Organic } & 15 \\ \text { Normal Paraffin Hydrocarbon } & 15\end{array}$

$\begin{array}{ll}\text { IV. PRODUCTS } & 18\end{array}$

$\begin{array}{lll}\text { V. PRINCIPAL INVESTIGATOR } & 18\end{array}$

VI. GENERAL TEST PROGRAM PREREQUISITES \& REQUIREMENTS 18

$\begin{array}{ll}\text { Prerequisites } & 18\end{array}$

Personnel Qualifications 18

- Safety 18

M\&TE 19

Pretest Verification $\quad 19$

$\begin{array}{ll}\text { Requirements } & 19\end{array}$

Expected Results/Acceptance Criteria 19

Documentation and Data Package Preparation 19

Change Control and Test Modifications 20

Data Review \& Evaluation 20

Instructions \& Procedures 21

Hazardous Materials Management. 21

Waste Disposal Plan 21

FIGURES

TABLE $\quad i i$ 
REVISION 0

Approval Date 2-7-89

\section{LIST OF FIGURES}

Number

Title

Page

Figure 1 Single Shell Tank - Flow Sheet for Sample Preparation

Figure 2 Single Shell Tank - Flow Sheet for Percent Solid Determination per CLP Method Part F, page D-84

Figure 3 Single Shell Tank - Flow Sheet for Water Leach per PNL Test Procedure Hiw

Figure 4 Single Shell Tank - Flow Sheet for Mofified EP Tox per SOW 846 Methods 1320

Figure 5 Single Shell Tank - Flaw Sheet for Acid Digestion per SOW 787 Page $0-4$

9

Figure 6 Single Shell Tank - F low Sheet for Mercury Analys is by Cold Vapor Technique per SOW 787 Modified Method 245.5

Figure 7 Single Shell Tank - Flow Sheet for Total Cyanide in in Sediment per EPA Method 9010 and CLP Method 335.2

Figure 8 Single Shell Tank - Flow Sheet for KOH Fusion Procedure

Figure 9 Single Shell Tank - Flow Sheet for Semivolatile Organic Method per SOW 787 Section D-2/SV

Figure 10 Single Shell Tank - Fiow Sheet for KPH Extractability Studies

\section{LIST OF TABLES}

Table I Radiochemical Measurements and Methods 
REVISION 0

Approval Date 2-1-89

TEST PLAN FOR ANALYSIS OF AREHIVE SST SAMPLES

\section{INTRODUCTION}

The purpose of this test plan is to describe the work and methods to be used for the analyses of archived Single-Shell Tank (SST) samples within PNL analytical laboratories. This work will be performed as part of PNL's SST Technology Support Program, Project 13924, under the Analytical Chemistry Task (WBS 8930).

\section{TEST SCOPE AND OBJECTIVES}

Work conducted under this test plan will consist of analyses of archive samples from SSTs 102-C, 105-C, and 106-C. As described in Section III, organic, inorganic, and the EP Tox analyses will be performed on the sample from SST 102-C and the radiochemical analyses on the sample from SST 105-C. The normal paraffin hydrocarbon test will utilize the sample from SST 106-C. The objectives of these tests are:

- To determine if there are problems with employing the various analytical methods on the test samples,

- To determine if the ICP has sufficient sensitivity for the analysis of EP Tox metal ions (excluding mercury, which will be anaiyzed by the cold vapor method),

- To deternine which of the 22 EPA pollutant metal ions can be deternined by ICP analysis,

- To determine if mercury can be determined by the cold vapor (CV) method,

- To determine whether the EPA Semivolatile Organic method can be employed on SST samples

- To determine solubility of inorganic and radiochemical ions in NPH

- To gather information on the radiological exposure and time durations required in utilizing the various methods, and

- To gather information relevant to the potential use of radionuclide ratioing and parent-daughter relationships for the estimation of radionuclides within samples.

The last two objectives support the evaluations which are being performed under the Alternative Techniques Task (WBS 8970). 
REVISION 0

Approval Date 2-1-89

\section{TEST METHODS}

\section{Sample Preparation}

Sampie preparation to establish homogeneity of the sample is outlined on Figure 1. The method of grinding and sieving the sample was selected since the previous archive SST sample was essentially a dry solid. A small portion of the previous archive sample showed some caking but these clumps were easily ground with a mortar and pestle and sieved.

\section{Percent Solids}

The percent solids determination method is outlined on Figure 2.

\section{Water Leach}

The water leach procedure is outlined on Figure 3 . The spike containing the anions is added at the beginning of the sample preparation scheme while the spike containing the cations is added after filtering the sample since the cation spike is prepared in an acid matrix. After filtering the sample, a $10 \mathrm{ml}$ aliquot of the three samples and the blank used for IC, TOC, and IIC analyses are removed from the hot cell. The exposure level of the IC samples will be determined at this time. If the exposure level of the IC samples is low enough to safely work with the sample outside of the hot cell, the samples for ICP analyses will also be removed from the hot cell and subsequent sample preparation done in an open faced hood. The concentrations of the various elements in the anion and cation spikes are selected based on the analyses of previous SST samples and the recommended CLP spiking levels in SOW 787 page E-10. If the ICP analysis detects a significant concentration of water solubie chromium (greater than $1 \mathrm{ug} / \mathrm{ml}$ ), an aliquot of the sample will be analyzed spectrophotometrically for chromium VI.

\section{EP Tox}

The modified EP Tox method is outlined on Figure 4. The spiking level for the EP Tox method was selected at the lower limit of the dangerous waste (DW) maximum concentration limits. After filtering the samples, $10 \mathrm{ml}$ aliquot of the two samples and the blank are removed for the cold vapor mercury analyses. The exposure level of the two aliquot will be determined when the samples are removed from the hot cell. If the exposure level of the $\mathrm{Hg}$ samples is sufficiently low, the $15 \mathrm{ml}$ aliquot for ICP analysis will be removed from the hot cells and the subsequent sample preparation will be done in an open faced hood. 
REVISION 0

Approval Date

\section{FIGURE 1 *}

SINGLE SHELL TANK

SAMPLE PREPARATION

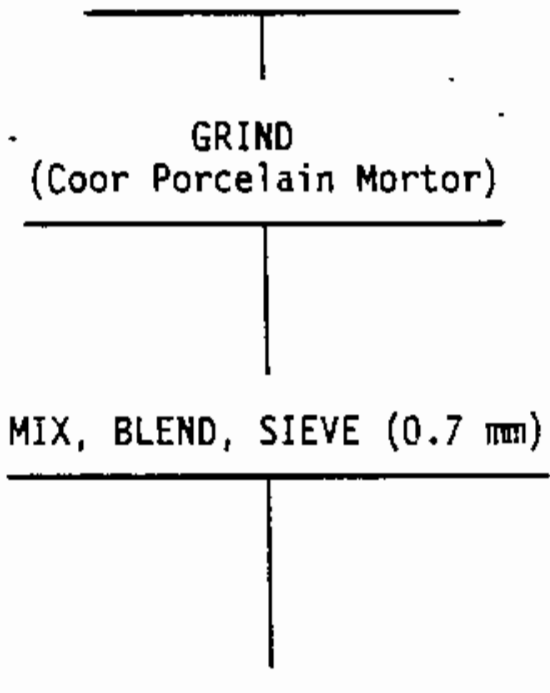

RETURN TO SAMPLE BOTTLE

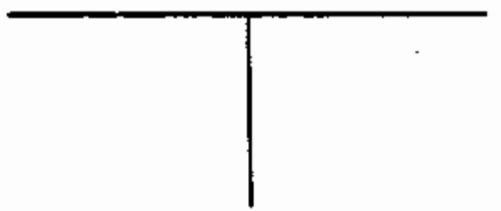

WEIGH SUBSAMPLES

As Shown on the following Sheets

A. 3 


\section{FIGURE 2 .}

\section{SINGLE SHELL TANK}

\section{Percent Solid Determination per CLP Method Part F page D-84}

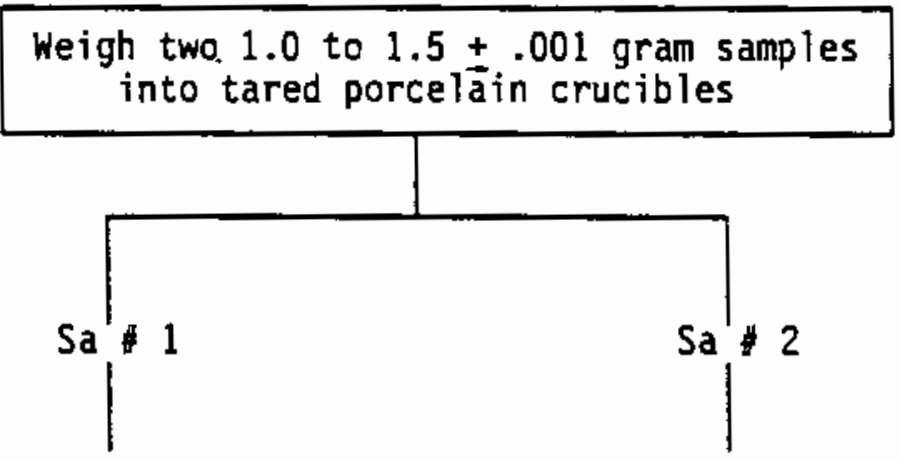

1. Place the crucibles into a drying oven maintained at 103-1050 $\mathrm{C}$.

2. Dry the sample overnight (12-24 hours) but no longer than 24 hours.

3. Cool the crucibles in a dessicator and weigh the samples to the nearest $0.001 \mathrm{~g}$.

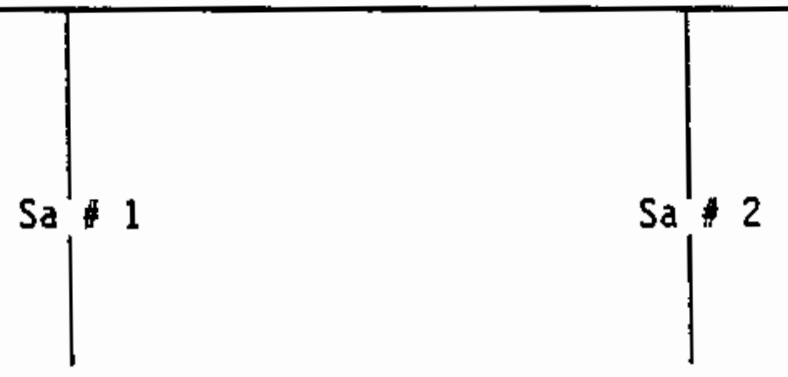


REVISION 0

Approval Date 2-]-89

FIGURE 3 .

SINGLE SHELL TANK

Water Leach

per PNL Test Procedure HWVP-1

Weigh three 1.0 to $1.5 \pm 0.001 \mathrm{~g}$ samples and place in a giass botties

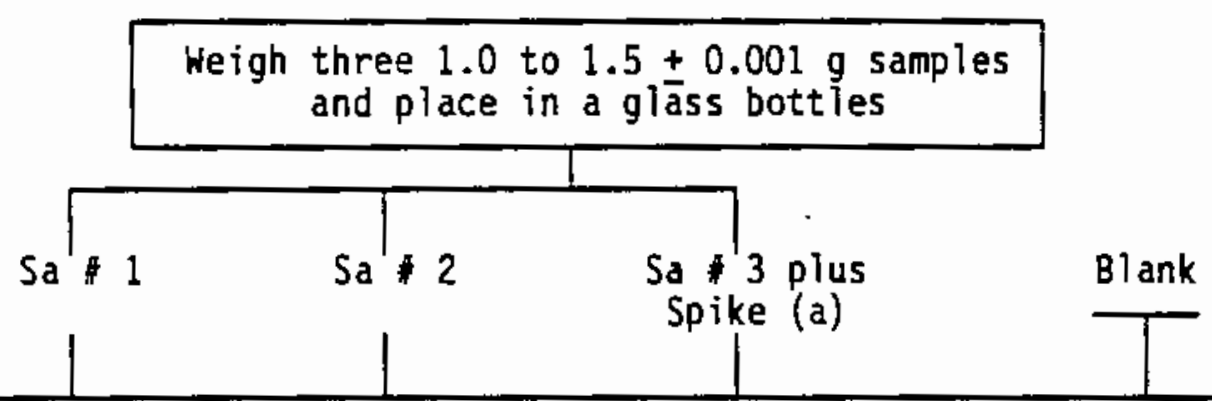

1. Add $100 \mathrm{ml}$ of DIW to the sample botties. On the spike sample, add $90 \mathrm{ml}$ of DIW and $10 \mathrm{ml}$ of the spike solution (a).

2. Cap the bottles and place in an vitrasonic bath for at least one hour.

3. Let the solution stand overnight and filter the supernate through 0.45 micron filter.

4. For IC, TOC and TIC, remove $10 \mathrm{mI}$ of the filtered solutions into approriate sample vials.

5. For ICP analysis, pipet $15 \mathrm{ki}$ of each of the filtered solution into tared glass vial containing $0.4 \mathrm{ml}$ of $1: 1 \mathrm{HCl}$. The third sample for ICP analyses is spike with soln (b).

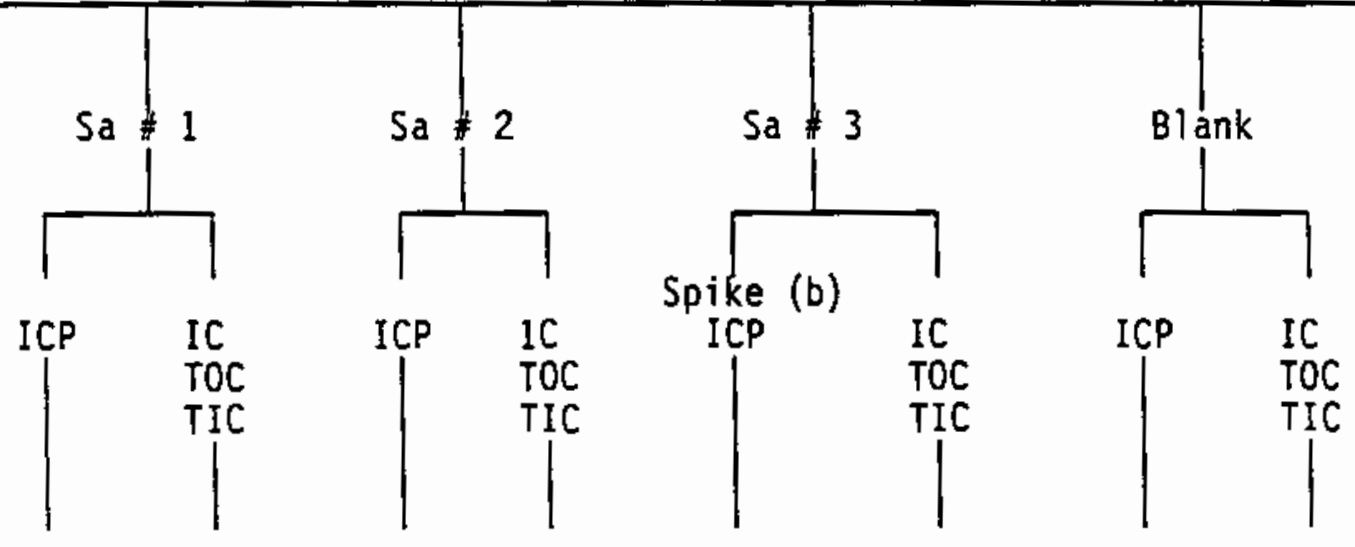

(a) Anion spike to contain 20 ug $\mathrm{F}-, 20$ ug $\mathrm{C}_{1-}, 100$ ug N03-, 1300 ug NO2-, 100 ug $\mathrm{PO}_{4}-3$, and 300 ug $\mathrm{SO}_{4}-2$ per $10 \mathrm{ml}$ of sample.

(b) Cation spike to contain 10 ug $\mathrm{Al}, 10 \mathrm{ug} \mathrm{Ba}, 10$ ug Bi, 5 ug $\mathrm{Cd}, 10 \mathrm{ug} \mathrm{Ca}$, 5 ug $\mathrm{Co}, 10 \mathrm{ug} \mathrm{Fe}, 10 \mathrm{ug} \mathrm{Pb}, 10$ ug $\mathrm{Mn}, 10$ ug $\mathrm{V}_{1} 100$ ug $\mathrm{P}_{1}, 40$ ug $\mathrm{K}, 10 \mathrm{ug}$ $\mathrm{Zr}, 10 \mathrm{ug} \mathrm{Cu}, 10$ ug Sb, 10 ug As, 0.5 ug Be, 20 ug Se, $20 \mathrm{ug} \mathrm{Ti}, 10 \mathrm{ug} \mathrm{V}$ and $10 \mathrm{ug} Z \mathrm{n}$ per $10 \mathrm{ml}$ of sample. The second solution to contain $50 \mathrm{ug}$ $\mathrm{Cr}$ as $\mathrm{Cr}^{+6}$ and 5 ug $\mathrm{Ag}$ per $10 \mathrm{ml}$ of sample.

(c) If spike recovery of anion sample 3 is not within limits of $75-125 \%$ an aliquot of filtered solution from sample 2 will be spiked and analyzed. 
REVISION 0

Modified EP TIGURE 4 TOX ${ }^{*} 846$

Approva 1 Date 2-1-89

Method 1310

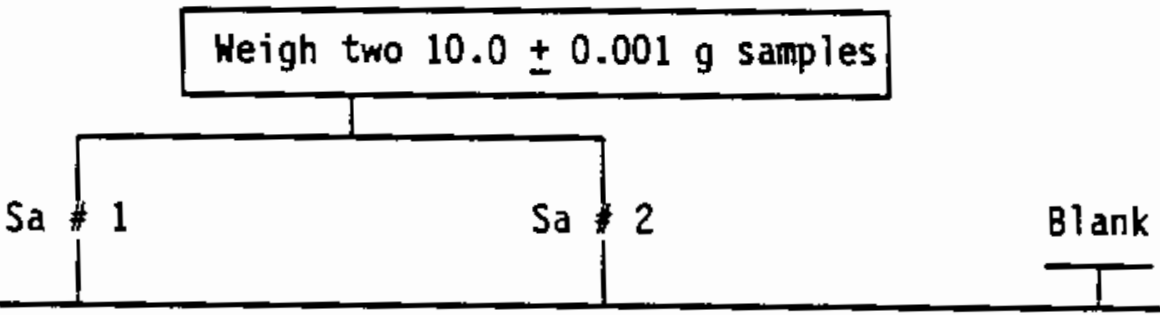

1. Add $160 \mathrm{ml}$ of $\mathrm{OIW}$. Agitate sample for 15 minutes and adjust the $\mathrm{pH}$ of the soln to $5.0 \pm 0.2 \mathrm{pH}$ units with $0.5 \mathrm{M}$ acetic acid. Keep track of the volume of acetic acid added. DO NOT add more than $4 \mathrm{ml}$ of acetic acid per gran of sample.

2. Agitate the sample for 15 minutes and adjust the $\mathrm{pH}$ to $5.0 \pm 0.2$ with $0.5 \mathrm{M}$ acetic acid.

3. Agitate the sample for 15 minutes and check the $\mathrm{pH}$. If the $\mathrm{pH}$ change of the soln is greater than $0.5 \mathrm{pH}$ units, repeat step 2 . If the $\mathrm{pH}$ change is $<0.5 \mathrm{pH}$ units, adjust the $\mathrm{pH}$ to $5.0+0.2$ units and agitate the sample for 30 minutes. Continue chëcking and adjusting the $\mathrm{pH}$ of the sample for six hours or until $4.0 \mathrm{ml}$ of $0.5 \mathrm{M}$ acetic acid per gran of sample has been added.

4. Continue agitating the sample for a total of 24 hours. If the total volume of acetic acid added is not $4.0 \mathrm{ml}$ per gram of sample continue checking and adjusting the $\mathrm{pH}$ of the sample to $5.0+0.2$ units each hour for an additional four hours.

5. Add DIW until the total volume of solution is $200 \mathrm{ml}$. Let the lids settle from the sample and filter the supernate using $0.45 \mathrm{~m}$ cron filter. Remove $10 \mathrm{ml}$ aliquots of Sa 1 and the blank sample for $\mathrm{Hg}$ analysis. Remove two $10 \mathrm{ml}$ aliquots of $\mathrm{Sa} / 2$ for $\mathrm{Hg}$ analysis.

1. Tare four glass bottles and add .2 $\mathrm{ml}$ of $1: 1 \mathrm{HNO}_{3}$ and $1 \mathrm{ml}$ of $1: 1$ HCI to each of the bottles. Add the appropriate volume of spike the bottle labeled "Spike".

2. Pipet $10 \mathrm{ml}$ of the appropriate filtered sample into each of the bottles.

3. Heat the samples in a hot water bath for 2 hours. Cool to room temperature and redilute the sample to approximately $10 \mathrm{ml}$ with OHW. Reweigh the sample bottle and record these weights. The final volume of sample in the vial is to be calculated from the solution weight assuming a density of 1.0 .

4. Remove the samples form the cell for ICP analysis.
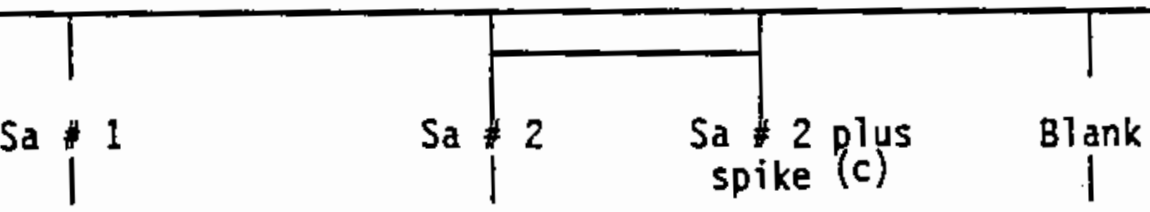
(c) Spike sample with $0.5 \mathrm{ml}$ of spike containing $100 \mathrm{ug} / \mathrm{ml} \mathrm{As,} 100 \mathrm{ug} / \mathrm{mi} \mathrm{Ba}$, $20 \mathrm{ug} / \mathrm{ml} \mathrm{Cd}, 100 \mathrm{ug} / \mathrm{ml} \mathrm{Cr}, 100 \mathrm{ug} / \mathrm{ml} \mathrm{Pb}, 20 \mathrm{ug} / \mathrm{ml} \mathrm{Se}, 100 \mathrm{ug} / \mathrm{ml} \mathrm{Ni}$ and $100 \mathrm{ug} / \mathrm{ml} \mathrm{Tl}$. Also add $0.5 \mathrm{ml}$ of $100 \mathrm{ug} / \mathrm{m}$ ] $\mathrm{Ag}$ solution. 
REVISION 0

Approval Date 2-1-89

\section{Acid Digestion}

Figure 5 outlines the acid digestion procedure. The procedure for sample preparation in the hot cell is the method from SOW 787 (CLP). The spike levels are determined from previous SST sample analysis and the recommended spike levels given on page E-10 of SOW 787 (CLP). The serial dilutions of $5 \times$ will be used to determine the accuracy of the major cations such as Al, Fe, Mn, $\mathrm{Ni}$, and $\mathrm{Na}$. Silicon will not be spiked since the results have no significance in an acid digested solution. The filter from the acid digested sample will be saved and the acid insoluble portion of the sample will be fused and analyzed on the ICP.

\section{Mercury Anatysis}

The method for mercury analys is is outlined on figure 6 . The sample digestion for mercury analysis is done in the hot cell. After the sample digestion, a preliminary separation of mercury is done in the hot cell by reducing the mercury with stannous chloride and the elemental mercury vapor is trapped into a mercury scrub media of $0.1 \mathrm{M} \mathrm{KMnO}_{4}$ in $5 \% \mathrm{H}_{2} \mathrm{SO}_{4}$. After trapping the mercury in the scrub media, the solution is removed from the hot cell and the mercury analysis completed using the cold vapor technique using a Perkin-Elmer $A A$ unit. If the duplicate samples agree within $\pm 20 \%$, a third sample will be spiked with a suitable aliquot of mercury and añalyzed. If the duplicate samples do not agree within $\pm 20 \%$, we must ascertain whether the discrepancy in duplicate samples is from sample nonhomogeneity or some unknown matrix interference in the sample.

\section{Total Cyanide}

The total cyanide method is outlined on Figure 7. The analyses are performed on duplicate 2 gram samples using the EPA distillation method 9010 . Since we know all SST samples will contain both nitrate and nitrite ions, sulfanic acid will be added to the distillation flask prior to the addition of sulfuric acid. If the duplicate samples agree with in $\pm 20 \%$, a third sample will be analyzed using an appropriate spike concentration. If the duplicate samples do not agree within the specified values ( $\mathrm{SOH} 787$ page $E-11)$, one would suspect a matrix problem.

\section{Fusion Procedure/Radionuclides}

The $\mathrm{KOH}$ fusion outlined on Figure 8 will be used to dissolve the sample for radiochemical analyses. The radiochemical isotopes measured and the methods of analyses are listed on Table 1. The objectives of this test are (1) Determine if the listed nonroutine and/or environmental radiochemical methods can be used to anaiyze SST samples, and (2) Gather information relevant to the use of radionuclide ratioing and parent-daughter relationships for estimation of radionuclides within samples. 


\section{FIGURE 5 .}

REVISION 0

Approval Date 2-1-89

\section{SINGLE SHELL TANK}

Acid Digestion

per SOW 787 page $0-4$

Heigh four 1.0 to $1.5 \pm 0.001 \mathrm{~g}$ samples

and place in $250^{\circ} \mathrm{ml}$ beakers

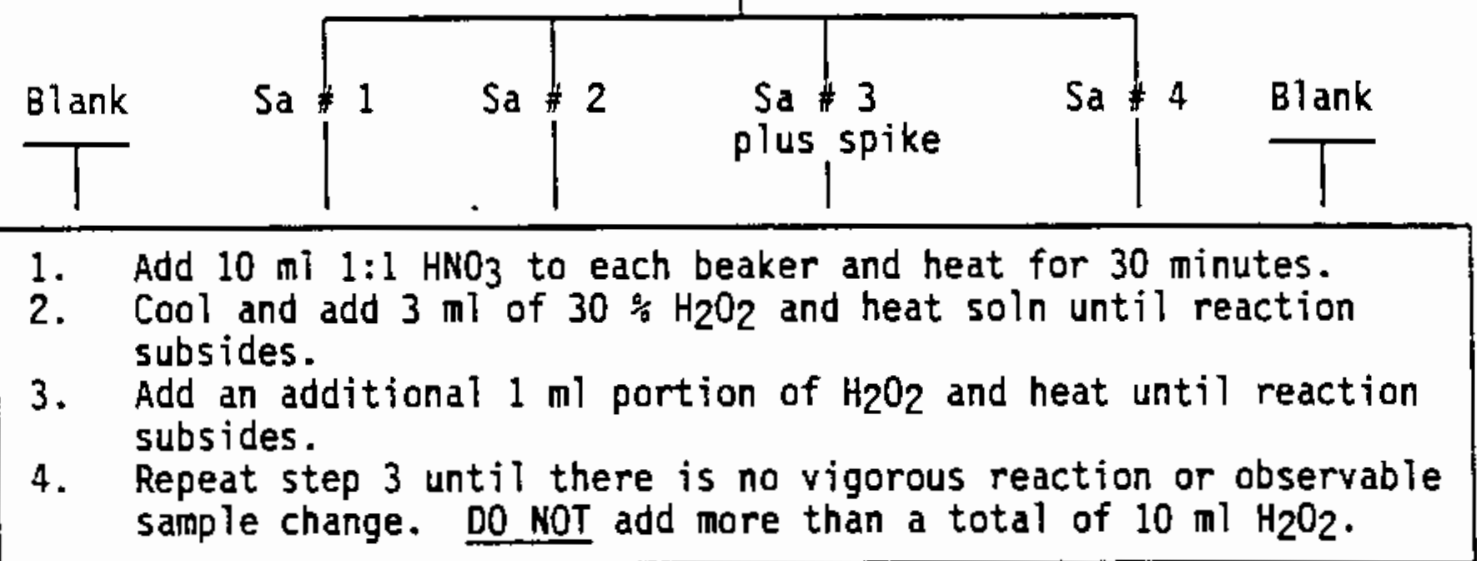

Heat the solutions for an additional 10 minutes.

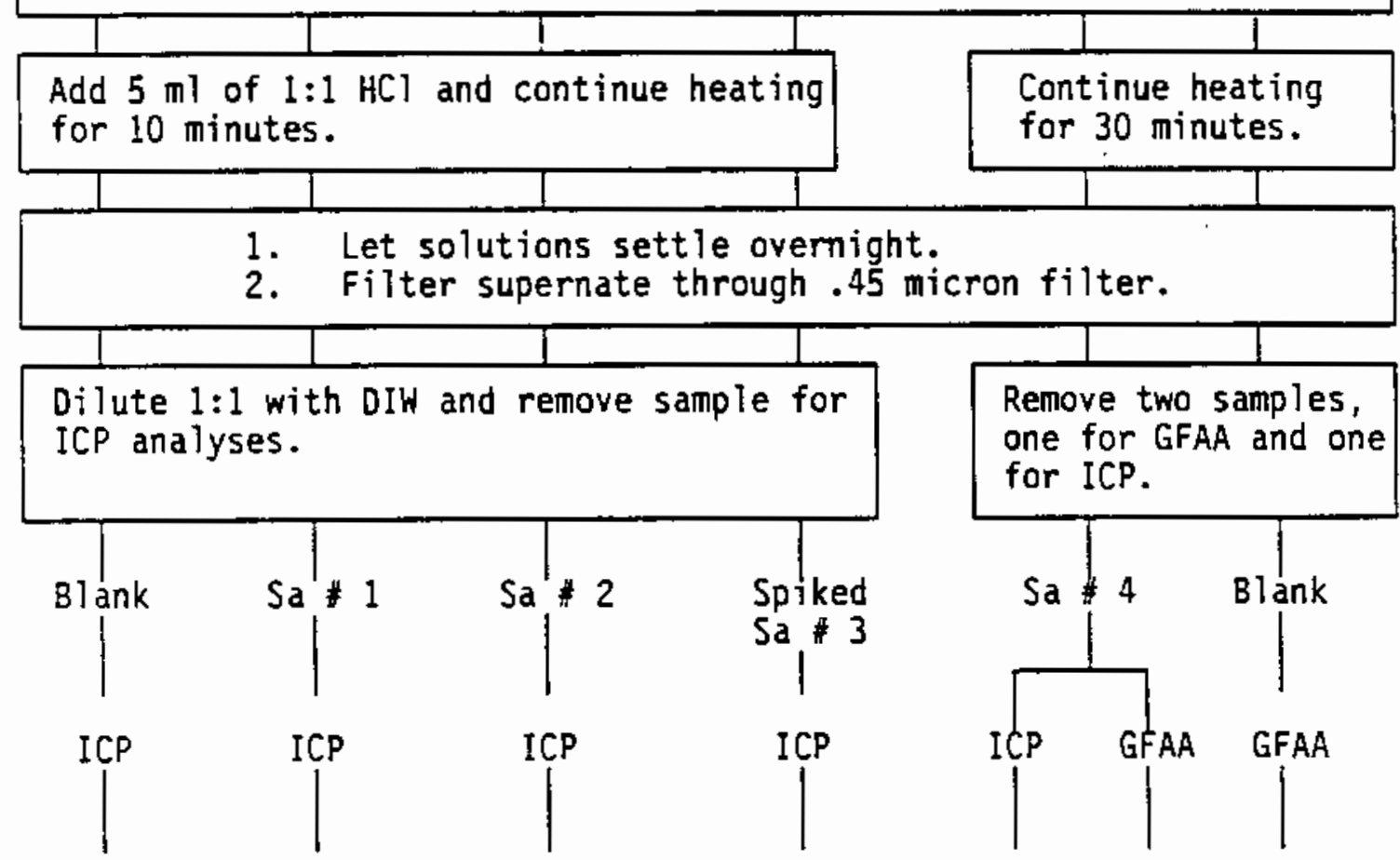

Spike to contain 20 ug $\mathrm{Ba}, 5$ ug $\mathrm{Cd}, 100 \mathrm{ug} \mathrm{Ca}, 100 \mathrm{ug} \mathrm{Cr}, 5 \mathrm{ug} \mathrm{Co}, 50 \mathrm{ug} \mathrm{Pb}$, $20 \mathrm{ug} \mathrm{Mg}, 100 \mathrm{ug} \mathrm{K}, 10 \mathrm{ug} \mathrm{Sr}, 10 \mathrm{ug} \mathrm{Zr}, 10 \mathrm{ug} \mathrm{Cu,5}$ ug Sb, 20 ug As,.5 ug Be,20 ug Tl, 5 ug $V$, and 5 ug $Z n$ per $10 \mathrm{ml}$ of sample. A second spike to contain 100 ug $P$ and 5 ug Ag per $10 \mathrm{ml}$ of sample 
Mercury Analyses by Cold Vapor Technique

per SOW 787 modified method $\mathbf{2 4 5 . 5}$
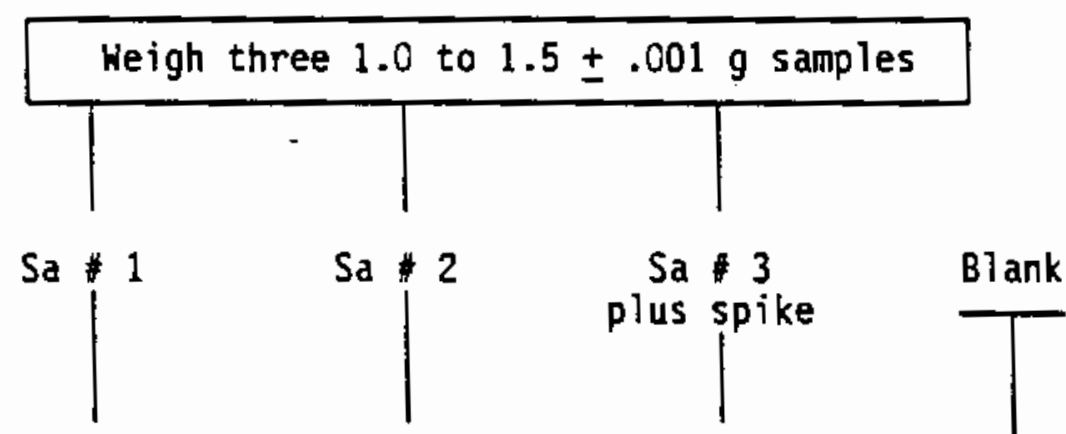

Perform sample digestion as per SOW 787 method 245.5. Using a $250 \mathrm{ml}$ erlenmeyer flask containing a mercury scrub media of $0.1 \mathrm{M} \mathrm{KMnO} 4$ in $5 \% \mathrm{H}_{2} \mathrm{SO}_{4}$, reduce the mercury in the sample with a stannous chloride solution and trap the mercury in the scrub media.

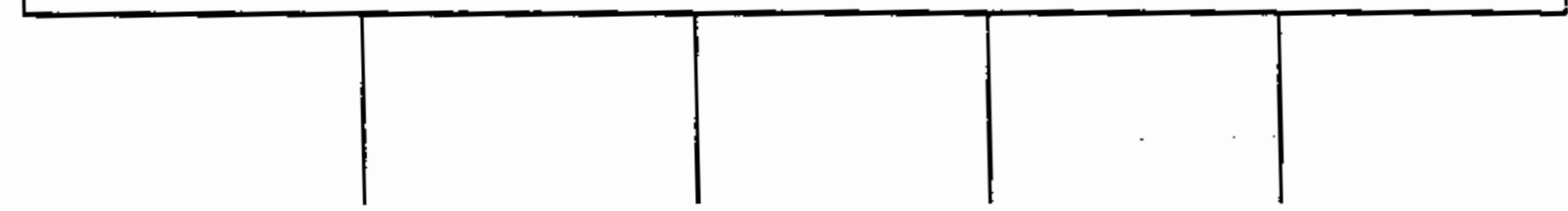

Remove the scrub media from the hot cell and determine the mercury on a suitable aliquot of the scrub media using the cold vapor mercury technique.

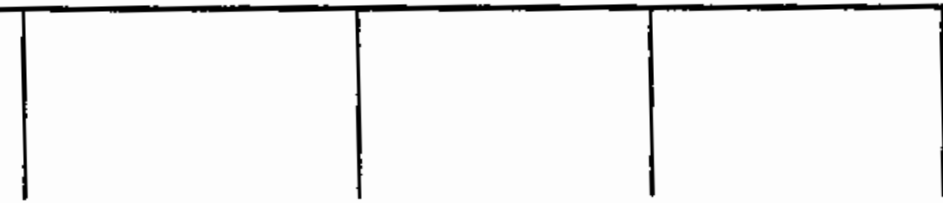

If the duplicate samples are reproducible within $+20 \%$, spike sample Sa 3 with a suitable aliquot of mercury and anaTyze. 
REVISION 0

Approvai Date 2-1-89

\section{FIGURE 7 .}

\section{SINGLE SHELL TANK}

Total Cyanide in Sediment per EPA Method 9010 and CLP Method 335.2
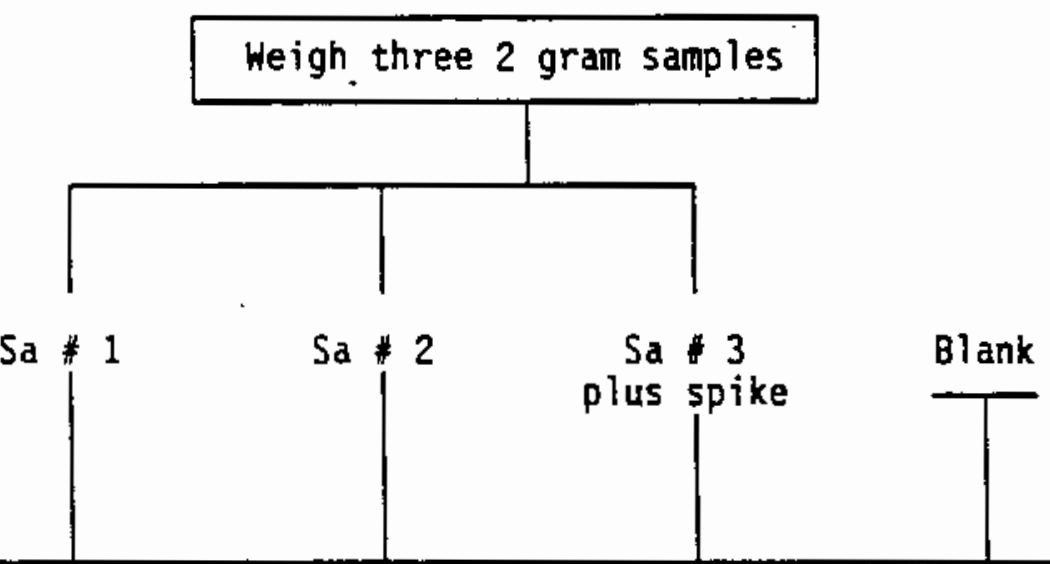

Perform the distillation procedure as outlined in EPA method 9010. add sulfamic acid to the sample since all SST samples will contain nitrates and nitrites. Remove the $\mathrm{NaOH}$ scrub solution from the hot cell and determined the $C N$ spectrophotometrically using the Hach it regents. If the duplicate samples agree within $+20 \%$, spike the third sample with a suitable aliquot of cyanide and analyzed.

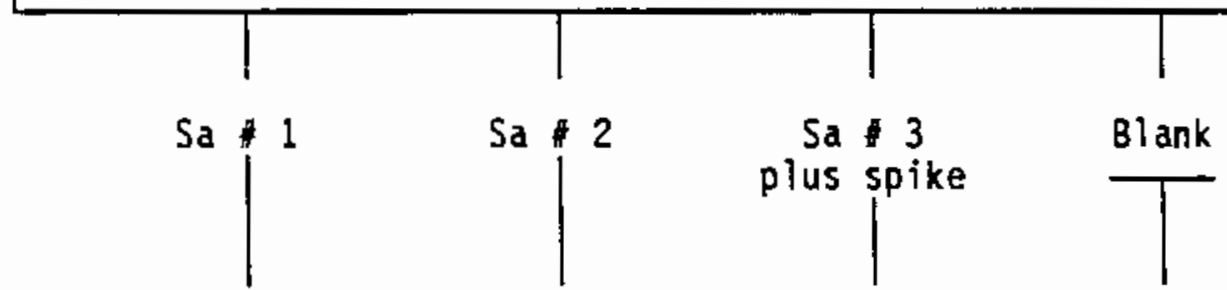


REVISION 0

Approval Date 2-1-89

FIGURE 8 .

SINGLE SHELL TANK

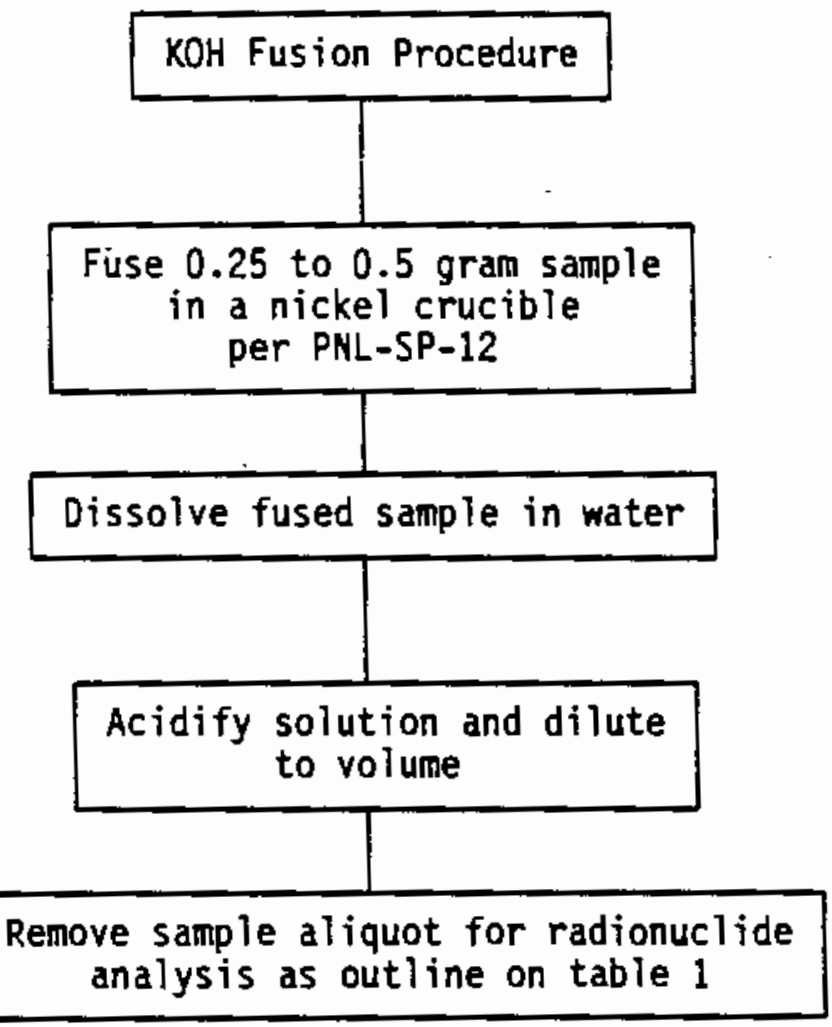

A. 12 
REVISION 0

Approval Date 2-1-89

Table 1

RADIOCHEMICAL MEASUREMENTS AND METHODS

\begin{tabular}{|c|c|c|}
\hline Item & Isotope & Procedure \\
\hline 1. & $227 \mathrm{AC}$ & PHL-AC-01 \\
\hline 2. & $\begin{array}{l}241 \mathrm{Am} \\
242 \mathrm{Am} \\
243 \mathrm{Am}\end{array}$ & $\begin{array}{l}\text { May require mass } \\
\text { spectrometer } \\
\text { analys is }\end{array}$ \\
\hline 3. & $242 \mathrm{Cm}$ & Included in Item 2 \\
\hline 4. & $\begin{array}{l}135 \mathrm{Cs} \\
137 \mathrm{Cs}\end{array}$ & $\begin{array}{l}\text { HTA-4-9 } \\
\text { HTA-4-40 } \\
3-30.6\end{array}$ \\
\hline 5. & $\begin{array}{l}59 \mathrm{Ni} \\
63 \mathrm{Ni}\end{array}$ & PNL-Ni-01 \\
\hline $6 .^{\circ}$ & $94 \mathrm{Nb}$ & PNL-Nb-01 \\
\hline 7. & $231 \mathrm{~Pa}$ & PNL-Pa-01 \\
\hline 8. & $210 \mathrm{pb}$ & $\begin{array}{l}\text { RSD-51-DIS6 } \\
\text { RSD-5i-DIS8 }\end{array}$ \\
\hline 9. & $210 \mathrm{po}$ & RSD-51-DIS8 \\
\hline 10. & $\begin{array}{l}238 \mathrm{Pu} \\
239 \mathrm{Pu} \\
240 \mathrm{Pu} \\
242 \mathrm{Pu}\end{array}$ & $\begin{array}{l}\text { HTA }-4-15 \\
2-30.5 \\
\text { HTA-4-22 } \\
\text { HTA-4-5 and/or }-6\end{array}$ \\
\hline 11. & $\begin{array}{l}226 \mathrm{Ra} \\
228 \mathrm{Ra}\end{array}$ & RSD-51-DEQ-4 \\
\hline 12. & ${ }^{79} \mathrm{Se}$ & HTA-4-18 or $7-40.15$ \\
\hline 13. & $151 \mathrm{Sm}$ & PNL-Sm-01 \\
\hline 14. & $\begin{array}{l}229 \mathrm{Th} \\
230 \mathrm{Th} \\
232 \mathrm{Th}\end{array}$ & RSD-51-DEQ-3 \\
\hline
\end{tabular}

$$
\text { A. } 13
$$


REVISION 0

Approval Date 2-1-89

Table 1(continued)

15.

$233 \mathrm{U}$

$234 \mathrm{U}$

$235 \mathrm{U}$

$236 \mathrm{U}$

$238 \mathrm{U}$

16.

$93 \mathrm{Zr}$

PNL-2r-01

17.

Total U

Total

HTA-4-16

$2-30.6$

HTA-4-36

Included in item 15

Included in itern 4 and 10 
REVISION 0

Approval Date 2-1-89

\section{Semivolatile Organic}

The analytical method for the analysis of semivolatile organic is outlined on Figure 9. The solvent extraction of the sample with methylene chloride will be performed in the hot cell. The organic phase is then removed from the cell and the drying and concentration steps will be done in an open faced hood. Again, the primary purpose of this test is to gain additional experience with the analysis on SST matrices. A portion of the sample will be saved to evaluate the screening method on the gas chromatograph/flame ionization detector (GC/FID) at a later date.

\section{Normal Paraffin Hydrocarbon}

The normal paraffin hydrocarbon (NPH) laboratory test will use the excess SST sample (241-C-106) presently in the 325 Building hot cell. The flowsheet for this experiment is shown on Figure 10. A slurry will be prepared in the hot cell by mixing the SST sample with the supernate from the 102-AX tank. This slurry will be contacted with an equal volume of KPH and the mixture stirred for 48 hours. The phases will be separated.

The NPH phase analyzed for total alpha, total beta, and a GEA. A portion of the NPH will be leached with water for the analysis of anions by IC. Another portion of $\mathrm{NPH}$ will be extracted with $1 \mathrm{M} \mathrm{HNO}_{3}$ and analyzed for cations. If the volume of separated KPH is insufficient for a water and an acid leach, the NPH will be extracted with DIH and the aqueous layer removed. The same NPH phase will then be extracted with $1 \mathrm{M} \mathrm{HNO}_{3}$ and both the aqueous sample and the $1 \mathrm{M} \mathrm{HNO}_{3}$ analyzed by ICP.

The objective of this experiment is to determine if the radionuclides, anions, and cations are KPH soluble. 
REVISION 0

Approval Date 2-1-89,

\section{FIGURE 9 .}

SINGLE SHELL TANK

Semivolatile Organic Method

per SOW 787 Section D-2/SV

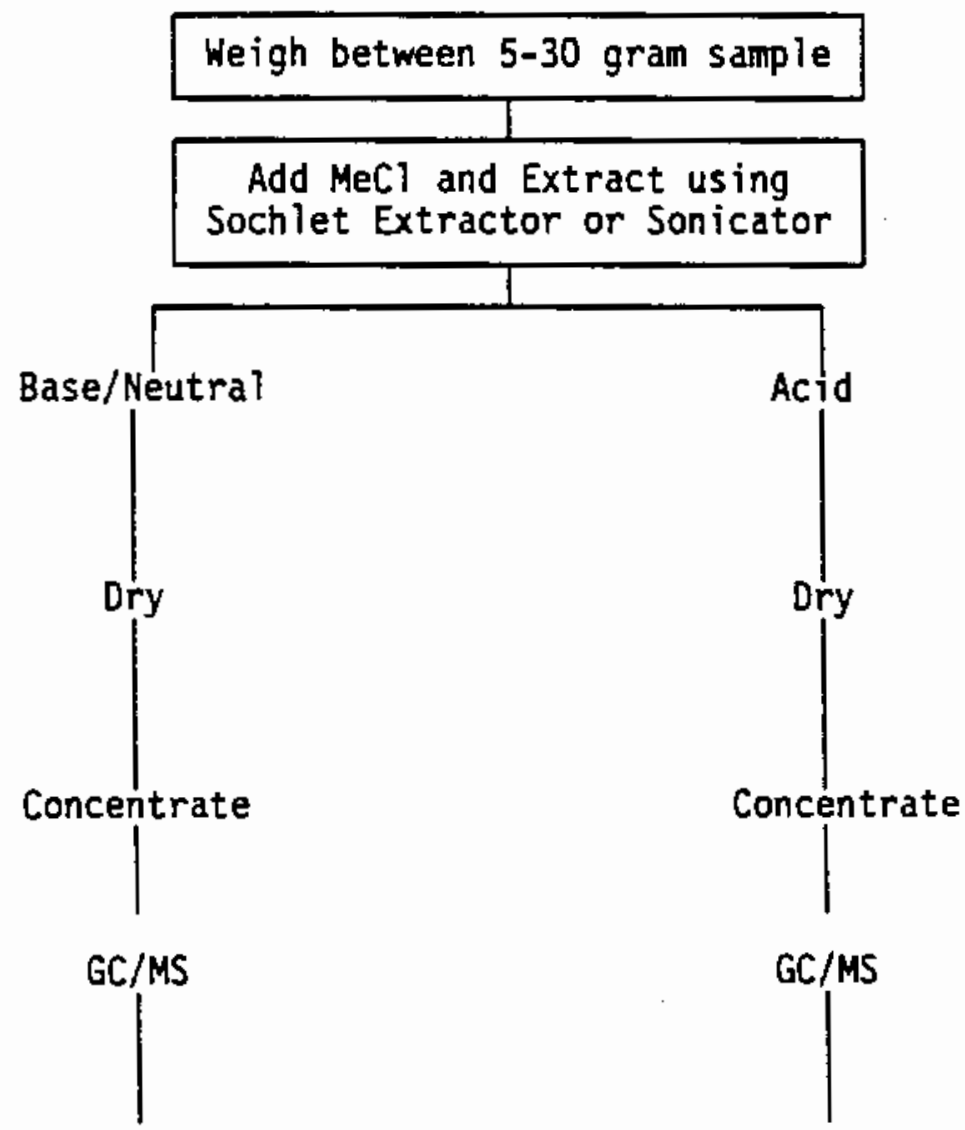

A portion of the sample will be saveu for screening analyses at a later date. 
NPH Extractability Studies

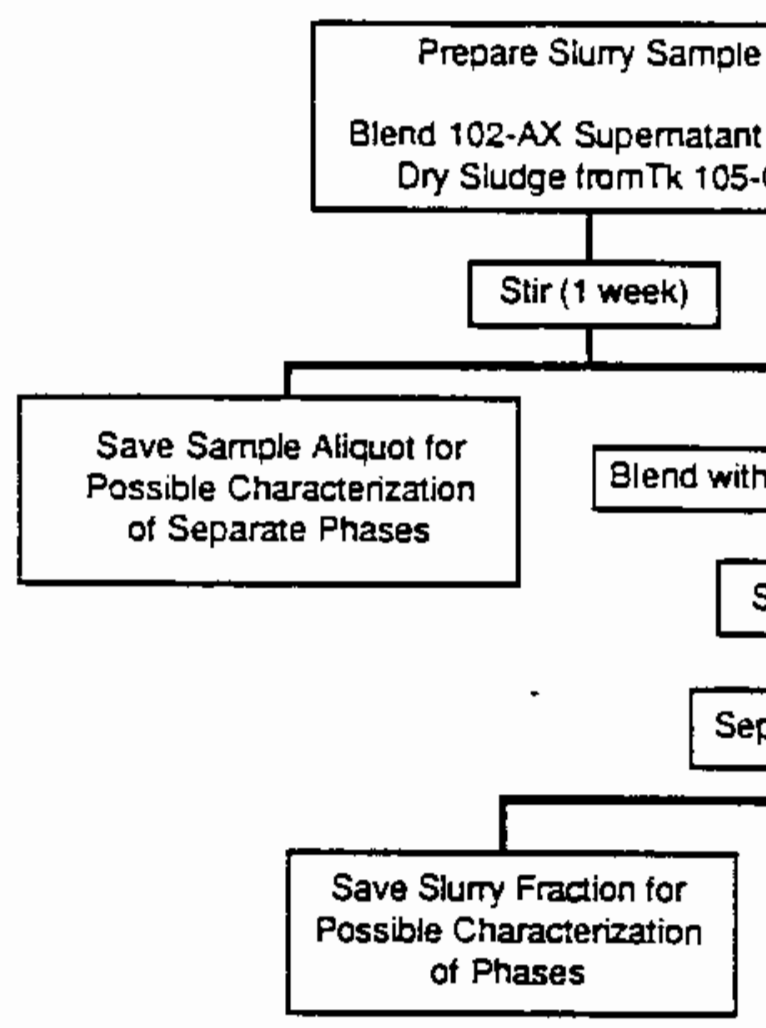

Save Sarnple Aliquot for ssible Charactenzation
REVISION 0.

Approval Date 2-1-89 
REVISION O

Approval Date 2-1-89

\section{PRODUCTS}

The products of this work are the final report and associated data packages and the residual archive samples from HHC and remaining quantities of derivative archive samples. Disposition of the physical archive materials will be as described in the Section VI "Test Program Perquisites and Requirements". The content of the final report is given next.

The report will be structured in two parts.

Part 1 wijl be a description of results and their significance covering the following four items and referencing the supporting data from the data packages. The four items are: (1) State results, identify problem areas and describe what actions are needed to solve the problems; (2) Radiological exposure data showing time and exposure for each step of a procedure; (3) Significance of field changes made and the relevant procedures, and (4) Radiochemical and radioisotope values which will be used in the Aitemative Techniques Task (HBS 8970) for comparison with TRAC data.

Part 2 will encompass all the backup information and data referenced in the first part. These data include the (1) Data Package for each method and the inputs to Alternative Techniques Task, (2) All data, including duplicate and serial dilutions and spike recoveries; and (3) copies of draft procedures not previousiy transmitted to HHC.

V. PRINCIPAL INVESTIGATOR

The Principal Investigator is FT Hara.

VI. TEST PROGRAM PREREQUISITES \& REQUIREMENTS

\section{Prerequisites}

Personnel Qualifications

The analysis methods being used to conduct the work are standard methods; personnel have been trained and qualified to perform these methods. No special additional training is needed.

\section{Safety}

The operations to be conducted during the work are standard analytical chemistry methods for which no unusual safety issues have been identified. The handing of radioactive samples will be controlied by the relevant radiation work permits and monitored by RPT. 
REVISION 0

Approval Date 2-1-89

\section{M\&TE}

Analysis procedures contain the requirements and practices for performing calibration and for standardization of instruments. Instrumentation will have caljbration stickers for items where calibration is required. The requirements for using calibrated instrumentation are described in the analytical procedures. Documentation for standards and calibration verification solutions are outlined in QA Plan, HTC-033, Rev 1.

\section{Material Identification \& Pretest Verifications}

Sample control and identification is in accordance with QA Plan WTC-033, Rev 1. Verification of condition of instrumentation and measuring systems is described in the analytical procedures. An instruction on Chain of Custody and appropriate format wil! be developed and implemented.

\section{Requirements}

\section{Expected Results/ Acceptance Criteria}

The purpose of the analysis work is qualitative and quantitative characterization to establish composition rather than to determine acceptability to some criteria. Results of the analysis work will also demonstrate that the available techniques and associated field changes will provide accurate and reproducible results.

Results will provide two types of information. First, analysis will quantify the EPA targeted inorganic and organic constituents SST samples. Second, radiochemical and radioisotope analyses will be used to better understand the ability of TRAC in predicting the radiochemical inventories of the SSTs.

Criteria for acceptability of the characterization data will be determined by the reproducibility of the duplicate analyses, serial dilutions and spike samples for organic and inorganic analyses. The organic and inorganic analyses will be done as outlined in the EPA (SW 846) and/or CLP (SOW 787) methods.

Data analyses and data reduction practices are outlined in the methods of anaiyses used.

\section{Documentation \& Data Package Preparation}

General documentation will be identified in the records index for task 8930. The principal investigator will define the specific data gathering processes to be used for each method and appropriate format. This data gathering feeds into the data package preparation. 
REVISION 0

Approval Date 2-1-89

Radiological exposure data will be documented for each procedure used on samples. Each step in each procedure will be evaluated and results documented on radiological exposure data sheet. These data sheets will be accumulated for each procedure. Precautions to limit/control background radiation for incell measurements will be described.

The radiological exposure data sheets will contain the following information: Origin of aliquot, name of analyst, Date, volume of aliquot, exposure levels at contact and 1 meter, description of operation, time started and time completed.

Data packages will be individually collated and reviewed for content and reproducibility in accordance with PNL-SA-30. Each data package wi\}l be signed by the Principal Investigator and Evaluator. PHL-SA-30 does not cover all the points for a data package for this project. An instruction for preparation of data packages will be prepared and implemented by the Principal Investigator to supplement PNL-SA-30.

Data packages will contain the following: Results of work including problem areas and proposed solutions; procedures used will be 1 isted and any field changes described; radiological exposure information showing time and exposure data; copies of draft procedures not previously transmitted to WHC, and all raw data. Raw data includes duplicates, serial dilutions and spike recovery, printouts, etc. Where data bases were developed they will be shown in hardcopy and a working disk provided.

Hazardous materials and waste information generated in the HMin task will be organized and retained for use in follow-on work with SST samples.

\section{Change Control and Test Modifications}

Changes to the technical content of test planning will require review and approval equivalent to that of the original; field changes during work will be documented and discussed with the project manager and included in the final data package. Changes in scope, cost or schedule require the approval of the line manager, project manager and customer.

Data Review \& Evaluation

Data review and evaluation will use a three stage process. First, the person(s) doing analysis will obtain the verification of their work by the Principal Investigator on a regular basis. Regular means with each set of analyses of each sample; review will be documented by initials and date in the appropriate place.

Second, Principal Investigator will review results in a systematic way to ensure that results are meaningful. This review will be used to determine when additional samples are to be run and/or when progress is deviating from expectations. 
REVISION 0

Approval Date 2-1-89

Third, the Independent Evaluator, per PAP-1101, will be appointed by the project manager and performs the following: (1) Independent review per PNLMA-70; (2) Concurs in the data packages, and (3) Concurs in the final report confirming that the results are consistent with the raw data, data reduction techniques were valid and the conclusions are supported by the data.

\section{Instructions and Procedures}

Analys is methods to be used are described in the test description. PNL Technical Procedures numbered PNL-SA-21 through-SA-50 are key routine procedures which will be followed during the work. These, in conjunction with the specific methods, provide additional administrative control ensures the quality of the data.

Procedures used, including field changes and test instructions, shall be adequate for a person familiar with the equipment and techniques to reproduce the data.

\section{Hazardous Materials Management}

The processes used will be evaluated for both personnel hazards and waste disposal and environmental requirements. The identification of chemicals and materials to be used and/or generated provide the basis for specific decisions. These data are used to identify any unique safety, environmental or waste issues and to chose between the various options for resolving issues. An example of an important issue would be handling excess input or derivative archive materials, waste streams treatment \& disposal.

Characteristics and volume(s) of materials used/generated are necessary for the development of a waste disposal plan, environmental compliance evaluation and decisions on need for MSDSs and hazards communication.

The waste disposal plan preparation and content are described below under "Requi rements".

The archive samples, provided by Hestinghouse Hanford Company, are radioactive mixed waste samples for characterization by PNL. Radioactive mixed waste materials must be controlled. Dilutions of these archive materials will be made to use as starting points for various analyses; these derivative archive samples will be identified as such and included in the discussions with HHC regarding disposition.

\section{Waste Disposal Plan}

A waste disposal plan will be prepared for the work and will be reviewed with Haste Management/Environmental Control section of Laboratory Safety. Preparation will be done in conjunction with 325 hot cell facility personnel. No disposal of liquids to the hot cell radioactive liquid waste sewer will be done prior to review and acceptance of the planning by Laboratory Safety. 
Planning will be based on identifed waste streams from each process step for each method, the composition and volumes using PNL-MA-8 for guidance and assistance from Laboratory Safety staff. This information is provided to Materials and Chemical Sciences Center Operations Manager for use in developing and updating waste projections.

Hazardous materials and waste information generated in the HMM task will be organized and retained for use in follow-on work with SST samples. 


\section{DISTRIBUTION}

No. of

Copies

OFFSITE

2 office of Scientific and

Technical Information

\section{ONSITE}

3 DOE Richland Operations

M. J. Anthony, A6-95

R. E. Gerton, $A 6-80$

R. D. Izatt, A6-95

54 Westinghouse Hanford Company

D. R. Bratze], T.6-50

A. J. Diliberto (50), R2-12

L. Jensen, T6-18

L. M. Sasaki, R2-12

W. I. Winters, T6-50
No. of

Copies

19 Pacific Northwest Laboratory

F. T. Hara, PB-41

J. H. Kaye, $P 7-22$

A. J. Schmidt (2), K2-12

R. T. Steele, P7-22

R. W. Stromatt, $P 7-22$

D. L. Thomas, P8-41

K. M. Toniney, K6-25

M. W. Urie, P7-22

R. S. Wegeng (5), K6-28

W. C. Weimer (2), P7-22

Publishing Coordination

Technical Report Files (2) 